UNIVERSIDADE DE SÃO PAULO

FACULDADE DE FILOSOFIA, LETRAS E CIÊNCIAS HUMANAS DEPARTAMENTO DE LETRAS CLÁSSICAS E VERNÁCULAS PROGRAMA DE PÓS-GRADUAÇÃO EM LITERATURA BRASILEIRA

FLAVIA TOGNI DO LAGO

Manuel Bandeira e Jules Laforgue:

Dor, ironia

Versão corrigida

São Paulo 


$$
\text { UNIVERSIDADE DE SÃO PAULO }
$$

FACULDADE DE FILOSOFIA, LETRAS E CIÊNCIAS HUMANAS DEPARTAMENTO DE LETRAS CLÁSSICAS E VERNÁCULAS PROGRAMA DE PÓS-GRADUAÇÃO EM LITERATURA BRASILEIRA

\author{
FLAVIA TOGNI DO LAGO
}

\title{
Manuel Bandeira e Jules Laforgue: \\ Dor, ironia
}

\begin{abstract}
Dissertação apresentada ao Programa de Pós-Graduação em Literatura Brasileira do Departamento de Letras Clássicas e Vernáculas da Faculdade de Filosofia, Letras e Ciências Humanas da Universidade de São Paulo, para obtenção do título de Mestre em Literatura Brasileira.
\end{abstract}

Orientadora: Profa. Dra. Yudith Rosenbaum

\section{Versão corrigida}

São Paulo 
Manuel Bandeira e Jules Laforgue: Dor, ironia

Flavia Togni do Lago

BANCA EXAMINADORA

Dissertação defendida e aprovada em: / 2012. 
A minha mãe, Ester, por ser dor e ironia, por inteiro. 


\section{AGRADECIMENTOS}

A Yudith Rosenbaum por me acompanhar nessa trajetória com confiança e carinho em conversas sempre marcadas por sua generosidade e sabedoria. A Guacira Marcondes Machado Leite, grande mestre, que em minha graduação me ensinou a caminhar pelas estradas da poesia. A Silvana Vieira da Silva, que esteve presente em momentos decisivos da minha formação. A Murilo Marcondes de Moura, que me encorajou nas leituras de Laforgue em um livro precioso. A Fernando Paixão e a José Miguel Wisnik pelas arguições no exame de qualificação que me deram a coragem para seguir em frente. Ao meu marido, Gustavo Henrique Dionisio, por fazer parte de cada palavra escrita e por compartilhar comigo suas inquietações sobre a vida e a arte. Ao meu pai por ser meu primeiro orientador e mestre da vida, que me incentivou desde sempre a buscar conhecimento. A minha avó, Deolice, fonte de sabedoria e amor. A minha irmã, Fernanda, e prima, Paula, pela carga poética vivida. A minha sogra, Inês, e meu sogro, Antônio, pelo carinho e torcida inconfundíveis. Aos amigos Pedro Reinato, Anita Silveira, Luciana Araujo, Cleuza Vilas Boas Bourgogne, Fernanda Machado, Carlos Eduardo Jordão Machado, Adilson Mendes e Denise Gonçalves por compartilharem suas ideias e comentários a respeito da literatura e por me ouvirem sempre com muito amor e atenção. As amigas Letícia Mendes, Sintia Mattar, Gabriela Castro, Livia Deorsola e Julia Bussius que me acolheram de forma carinhosa em suas vidas paulistanas. A Rosângela Baptista Nacagami e Roberta Baptista Nacagami por serem muitas vezes minha segunda família em São Paulo. As amigas Natália Fadel Barcellos, Juliana Santos de Souza, Carolina Domladovac Silva, Maura Mendes, Michelle Cunha de Mello e Camila Izoli pelos anos inesquecíveis em Araraquara. E por fim, aos amigos da Cosac \& Naify, Saraiva e Vergara \& Riba por compreenderem as tantas horas dedicadas a este trabalho individual. 
$E$, se forma longa e difícil, a dor abre uma brecha para as palavras.

VIRGÍLIO, ENEIDA, XI, 151

Só depois deste grito a ironia regressa,

Dizendo, quando muito:

Morro, é certo, mas mesmo assim

Guardo uma elegante distância em relação

à minha morte.

GONÇALO M. TAVARES, UMA VIAGEM À ÍNDIA:

MELANCOLIA CONTEMPORÂNEA (UM ITINERÁRIO) 


\section{RESUMO}

O presente trabalho consiste em apresentar uma leitura de poemas de Manuel Bandeira e Jules Laforgue com o objetivo de trazer a discussão a respeito da dor e da ironia nas duas obras. O estudo tem como objetivo principal ampliar a reflexão sobre a ironia bandeiriana, a partir de elementos relacionados com a obra de Jules Laforgue. Como pudemos comprovar, Bandeira foi um grande admirador e leitor do poeta francês, e embora haja diferenças visíveis entre as obras, estes mesmos pontos de afastamento nos ajudarão a compreender o processo criativo que resultará na construção da ironia em Bandeira. Tentamos recuperar poemas relacionados a um dos temas principais das obras: a morte. Aos poucos, para Manuel Bandeira, veremos que a dor da finitude se transforma em recolhimento e sabedoria, num processo de maturação crescente que acompanha a abertura para o modernismo. Sendo assim, a ironia de Laforgue pode ser considerada mais cruel, ou seja, ela é aparentemente utilizada como arma de defesa ou de libertação de seu desejo de morte presente desde os seus primeiros versos. Em Bandeira, a ironia se relaciona diretamente ao par morte/superação, ou seja, podemos dizer que a ironia banderiana é uma ironia residual, onde após a experiência da dor e do aprendizado para a morte, seria possível rir. A partir dessas primeiras elaborações, a figura do Pierrot transformou-se num ponto de convergência das duas obras, sintetizando em sua imagem os temas trabalhados nesta pesquisa: dor e ironia.

Palavras-chave: Poesia; Dor; Ironia; Literatura Brasileira; Literatura Francesa; Modernismo; Simbolismo. 


\section{RÉSUMÉ}

Ce travail propose une lecture critique des poèmes de Manuel Bandeira et de Jules Laforgue en s'appuyant sur les thèmes de la douleur et de l'ironie observés au sein des deux œuvres. Notre objectif principal est d'approfondir notre réflexion sur l'ironie de Manuel Bandeira, à partir d'éléments rencontrés dans l'œuvre de Jules Laforgue. Comme nous le souhaitons le démontrer, Bandeira fut un grand admirateur et lecteur du poète français et bien qu'il existe des différences notables entre les deux œuvres, ces oppositions nous serviront à comprendre le processus créatif comme aboutissement de la construction de l'ironie chez Bandeira. Nous tentons de récupérer des poèmes en lien avec l'un des thèmes principaux des œuvres : la mort. Peu à peu, nous verrons que chez Bandeira, la douleur de la fin se transforme dans une quête de savoir et dans un recueil, dans un processus de maturation évolutif qui accompagne l'ouverture du modernisme. En considérant cela, l'ironie de Laforgue peut être considérée plus cruelle : elle est en effet utilisée comme une arme de défense ou de libération de son désir de mort, présent sans ses premiers vers. Chez Bandeira, l'ironie est directement liée à la mort. C'est pourquoi nous pouvons dire que chez Bandeira, l'ironie est une ironie résiduel qui, au-delà de l'expérience de la douleur et de l'apprentissage de la mort, peut provoquer rire. A partir de ces premières élaborations, la figure de Pierrot se transforme en un point de convergence des deux œuvres, synthétisant en son image, les thèmes travaillés dans cette recherche : la douleur et l'ironie.

Mots-clés: Poésie; Douleur; Ironie; Littérature Brésilienne; Littérature Française ; Modernisme ; Symbolisme. 


\section{ABSTRACT}

This study consists to present one reading of Manuel Bandeira and Jules Laforgue poems, with a specific objective: to estabilish a discussion on pain and irony in both poethical works. The main subject of this investigation intends to make a contribution on the bandeirian irony - in one hand -, related to some meaningfull elements of Laforgue's work - in another. As we can see, Bandeira was, indeed, not only a reader but also a great admiror of the french poet; and instead one can observe some artistic differences between them, these points of distance will help us understand the creative process of Bandeira's irony. First of all, the study recovers the death theme in the earliest poems of both authors. In consequence, we could verify that in Bandeira's earliest books this theme is permeated by an idea of overcoming and, in the opposite hand of Laforgue, here death emerges as the only way of reconciliation with the world. Thus, we shall consider that the irony in Laforgue's work is more "cruel", it's apparently used as a defensive or liberator weapon towards his death desire, which is presented since his earliest verses. In Bandeira, instead, irony is directly related to death as an overcoming, i.e, his irony is residual, allowing him to laugh after all the pain of life learning experienced. After this initial findings, the image of the Pierrot emerges as a point of convergence between the two works, summarizing in one figure the most important themes studied in this research: pain and irony.

Key-Words: Poetry, Pain, Irony, Brazilian Literature, French Literature, Modernism, Simbolism. 


\section{SUMÁRIO}

Introdução

Manuel Bandeira e Jules Laforgue, modernidade em dois tempos

p. 11

\section{Capítulo 1 | O TEMPO E AS OBRAS}

1.1 Manuel Bandeira e a trajetória de uma obra

p. 16

1.2 Jules Laforgue: Decadentismo e Simbolismo na França do final do século XIX

p. 24

\section{Capítulo 2 | A CONSTRUÇÃO DA MATÉRIA IRÔNICA}

2.1 "A própria dor é uma felicidade": Manuel Bandeira

p. 34

2.1.1 O canto do poeta "menor" e irônico

p. 49

2.2 A escolha pelo desabafo "Que je suis piètre et sans génie":

Jules Laforgue

p. 56

\section{Capítulo 3 | UM CONCEITO VERTIGINOSO}

$\begin{array}{lll}3.1 & \text { Breve conceito de ironia } & \text { p. } 82\end{array}$

$\begin{array}{lll}3.1 .1 & \text { (Se) perguntar vale a pena? } & \text { p. } 83\end{array}$

3.1.2 De perto e de longe: do romantismo alemão à modernidade p. 87

3.2 Diálogos entre dois Pierrots: uma aproximação entre a dor e a ironia p.93

$\begin{array}{lll}3.3 & \text { Pierrot apaixonado p. } 105\end{array}$

$\begin{array}{lr}\text { a) O salão báquico } & \text { p. } 115\end{array}$

$\begin{array}{lr}\text { b) Um dolorido contracanto } & \text { p. } 117\end{array}$

$\begin{array}{lr}\text { c) } O \text { salto rumo às estrelas } & \text { p. } 118\end{array}$

Considerações finais

"Sono Il saltimbanco dell'anima mia" $\quad$ p. 121

$\begin{array}{lr}\text { Referências bibliográficas } & \text { p. } 125\end{array}$ 
INTRODUÇÃO | MANUEL BANDEIRA E JULES LAFORGUE, MODERNIDADE EM DOIS TEMPOS 
Em 1940, com o falecimento de Luís Guimarães Filho, foi aberta a inscrição para a cadeira vinte e quatro da Academia Brasileira de Letras. Diante desse fato, Ribeiro Couto, Cassiano Ricardo e Múcio Leão foram ao bairro de Santa Tereza visitar o amigo Manuel Bandeira. O motivo da visita era evidente: os amigos queriam convencer o poeta a apresentar sua candidatura.

Naquela época, Bandeira já era considerado um dos grandes nomes de nossa literatura, mas candidatar-se não Ihe parecia algo completamente natural. Afirmou, nessa ocasião, que sua hesitação não vinha de um preconceito antiacadêmico, mas suas ojerizas estavam ironicamente relacionadas a duas exigências: o fato de vestir o fardão e o emblema da casa "Ouro, louro, imortalidade me horrorizavam".

Foi então que, em 30 de novembro de 1940, Bandeira foi eleito por 21 votos. Após a notícia, o poeta viu-se em apuros: era preciso escrever seu discurso de posse. Em um primeiro momento, tentara a inspiração por meio de Valéry, integrante da Academia Francesa cujo discurso era apreciado por Bandeira pelo seu "tom e ritmo conveniente". Contudo, de acordo com suas declarações em Itinerário de Pasárgada:

Li-o e me senti, ai de mim, na maior depressão moral. Me senti como que desamparado. Que je suis piètre et sans génie!, ${ }^{1}$ disse comigo mesmo, repetindo o verso de Laforgue, alterado por mim especialmente para me servir de desabafo em ocasiões como essa. (BANDEIRA: 1984 [1954], p. 112)

Não foi a primeira vez que Bandeira utilizou esse verso de Jules Laforgue para consolo de suas aflições. Em uma carta a Mário de Andrade, em 3 de setembro de 1927, em resposta ao amigo, afirma:

Sim Mário! é uma bruta felicidade essa de a gente poder fazer versos. Aquele "Profundamente" fez a minha consolação durante bem uns quinze dias. Se Deus me desse uma coisa dessas em 15 dias eu aceitaria sem tanta amargura meu destino. Mas o meu pão de cada dia é o "je suis piètre

\footnotetext{
1 Tradução nossa: "Como sou medíocre e sem talento".
} 
et sans génie" de Laforgue ([BANDEIRA [1927] apud MORAES, 2001, p. 353).

Esse verso, adaptado por Bandeira na primeira pessoa do singular, fora retirado do poema "Complainte pour certains ennuis" [Lamento para certos desgostos], publicado originalmente em 1885, no livro intitulado Les Complaintes [Os lamentos]. ${ }^{2}$ É a partir dessa adaptação que nosso entrelaçamento se inicia. Caberá a nós, portanto, continuarmos a trama para que se vejam nela os pontos de intersecção e de afastamento entre as duas obras.

O princípio deste trabalho teve sua origem em uma pesquisa iniciada em 2003 que mais tarde deu origem a um projeto de Iniciação Científica realizado na UNESP Araraquara, sob a orientação da Prof. Dra. Guacira Marcondes Machado Leite, onde tratamos da relação entre Oralidade e Simbolismo na poesia de Manuel Bandeira. Procuramos relacionar a obra do poeta brasileiro com poetas simbolistas franceses do final do século XIX. Entre eles, Jules Laforgue foi o poeta pelo qual adquirimos um interesse particular quando realizamos as análises e comparações. Ao desenvolver um breve estudo sobre sua obra poética, escolhemos como ponto de partida seu livro intitulado Les Complaintes.

Neste primeiro momento, a proposta seria investigar a relação entre Manuel Bandeira e Jules Laforgue a partir da influência simbolista e também avaliar de que forma a tradição oral estaria inserida nas duas obras. Porém, levando em consideração as inúmeras influências sofridas por Manuel Bandeira, não apenas das correntes literárias europeias, mas também de tradições populares, o tema nos pareceu muito amplo para ser explorado.

Anos mais tarde, com 0 amadurecimento da ideia inicial, o questionamento sobre a ironia surgiu em algumas releituras de poemas. Mas 0 que de fato ligava os poetas a partir desse tema?

\footnotetext{
${ }^{2}$ Registramos aqui a estrofe original de onde o verso adaptado por Manuel Bandeira fora extraído: "Un couchant des Cosmogonies!/ Ah! que la Vie est quotidienne.../ Et, du plus vrai qu'on se souvienne,/ Comme on fut piètre et sans génie..." ("Complaintes des certains ennuis", in Les Complaintes. Paris: Imprimerie Nationale, 2000, p. 109).
} 
Nestas releituras, percebemos, então, que um primeiro indício estaria bastante relacionado ao verso citado no início deste trabalho. Além de estarem inicialmente ligados através da adaptação utilizada por Bandeira como uma espécie de "mantra" pessoal, o tom empregado pelos dois autores é o de um humor melancólico ou, em outras vezes, de uma melancolia humorada. Pois, ao se afirmarem "medíocres", por exemplo, há por trás dessa ironia uma certa melancolia, que se relaciona com dupla capacidade de autojulgamento, representando uma sombra constante, algo que paira em suas experiências líricas.

Isto nos levou a observar a experiência de vida dos dois poetas. Bandeira, ainda que tísico, sobreviveu à doença e sua obra terá inúmeras interferências diretas da "vida inteira que poderia ter sido e não foi". Laforgue, tuberculoso como Bandeira, morre, no entanto, aos 27 anos e também deixa traços em sua obra com suas angústias e inquietudes perante o tema da morte. O fator da doença presente na vida dos dois autores torna, portanto, a questão biográfica um elemento inequívoco: para Laforgue, não houve tempo suficiente para uma "preparação para a morte", ao contrário de Bandeira que através desse convívio duradouro com a ideia de finitude acabou desenvolvendo uma série de mecanismos de superação em sua poesia.

Para encontrar respostas sobre quais foram os caminhos percorridos durante o convívio com a ideia da morte, recolhemos, no primeiro capítulo, informações seguindo o recorte histórico-estilístico dentro do qual cada poeta esteve inserido. A primeira consonância entre os autores está relacionada com a dificuldade de classificação de suas obras, seja pelo viés estilístico, seja pelas vastas influências sofridas por cada um deles.

Mais diretamente relacionada ao desenvolvimento do projeto simbólico da poesia dita moderna, em que o individualismo era uma das características essenciais dessa modernidade, a poesia de Jules Laforgue se transformará no espaço adequado para as cenas cotidianas e a negatividade, ultrapassando as classificações do Decadentismo ou Simbolismo.

Para Bandeira, veremos que tal modernidade corresponde ao resultado de quase um século de experiências e discussões sobre o papel e o lugar da poesia. O começo de sua obra tem a presença marcante das correntes 
poéticas provenientes do final do século XIX. Ainda que com características peculiares, seus primeiros versos revelam as influências parnasianosimbolistas ou ainda, crepusculares. Mais tarde, o poeta antecipará a evolução modernista e a ela se integrará como uma de suas vozes mais representativas.

Partindo da ideia de proximidade com a morte e o traço melancólico de muitos versos, no segundo capítulo analisaremos poemas que nos ajudarão a compreentender a relação do eu lírico bandeiriano e o "je" laforgueano com a dor. Nos poemas de Manuel Bandeira, buscaremos relações entre a morte e a superação, uma das características mais positivas da obra bandeiriana. Em Laforgue, mostraremos como o tema da morte e da dor está diretamente relacionado ao seu projeto particular em busca de uma poesia "original". Essas análises nos levarão ao tema seguinte: a ironia.

No terceiro capítulo, iniciaremos o percurso pelo conceito de ironia, considerando suas origens filosóficas e, em seguida, sua utilização pela Retórica e pelo Romantismo alemão. Nestas considerações tentaremos levantar a hipótese de que o conceito nem sempre estará ligado ao aspecto cômico, mas sim ao caráter de mudança, inversão de uma perspectiva habitual. Assim, os elementos do cotidiano, a linguagem despojada, o verso livre, a autoderrisão estarão intimamente relacionados à ironia utilizada nos versos de Manuel Bandeira e Jules Laforgue. E, através de uma espécie de "moral irônica", ${ }^{3}$ veremos como cada poeta irá construir maneiras de tratar a dor.

$\mathrm{Na}$ última parte do trabalho, como espécie de síntese dos dois primeiros capítulos, trabalharemos as análises de dois poemas que trazem a figura do Pierrot na posição de eu lírico. Este personagem da Commedia dell'Arte será o porta-voz dos temas trabalhados nesta pesquisa. Além de elementos formais bastante próximos, o universo do picadeiro, as brincadeiras carnavalescas tornam-se o palco para a reflexão dos temas da dor e ironia propostos nesta dissertação.

\footnotetext{
${ }^{3}$ Este termo é citado no terceiro capítulo e pertence ao filósofo Ortega y Gasset em seu livro La deshumanización del arte y otros ensayos de estética. Madri: Austral, 2006.
} 
CAPÍTULO 1 | O TEMPO E AS OBRAS 


\subsection{Manuel Bandeira e a trajetória de uma obra}

O estudo da obra de Manuel Bandeira e a sua apresentação não é uma tarefa fácil. Muito antes de dar início às justificativas das dificuldades encontradas no caminho, vale dar um breve panorama do seu lugar e importância no contexto histórico-literário brasileiro. Dessa forma, já conseguiremos visualizar em quais pontos a obra de Bandeira se distancia ou se aproxima de Jules Laforgue.

Ao percorrer a trajetória poética de Manuel Bandeira deparamos com uma variedade estilística de diversas vertentes como o classicismo português, o romantismo, o parnasianismo, o simbolismo, o penumbrismo, as vanguardas europeias e o modernismo brasileiro. A experimentação e a elaboração dessas interferências são fatores fundamentais para o período de transição (nas duas primeiras décadas do século $X X)$ em que a estética passadista é superada e 0 poeta se firma no terreno da modernidade.

Assim como afirmou Murilo Marcondes de Moura, "Manuel Bandeira foi lido por Machado de Assis e sobreviveu a Guimarães Rosa" (MOURA, 2001, p. 8). A afirmação, de acordo com o crítico pode soar como um disparate, mas é perfeita para pensarmos a extensão do longo espaço de tempo em que Manuel Bandeira atuou na poesia brasileira. Ainda de acordo com Moura, esse espaço de tempo é tão dilatado quanto singular, "pois é comunicante entre a tradição e a modernidade". Contudo, é importante ressaltar que essa "versatilidade" de Bandeira não pode ser confundida com um simples ecletismo formal. A prática e a concepção da voz lírica bandeiriana foram naturalmente adensadas ao longo dos anos, mas não há como traçar sua trajetória por meio de um recorte retilíneo de evolução. Sobre isso, nota Sergio Buarque de Holanda que

um censor superficial e desatento falaria em versatilidade a propósito da aptidão com que essa poesia se ajusta a todos os compassos, mas isso não explica a unidade profunda que subsiste em tudo quanto escreveu Manuel Bandeira. Unidade na variedade. (HOLANDA, 1996, p. 282) 
Perceber, então, a obra de Bandeira numa intersecção de estilos é o que nos permite apreender melhor sua complexidade. Pois como bem sabemos, o poeta pernambucano nunca esteve preso a nenhuma escola, forjando um caminho próprio e inconfundível. Sua poesia jamais esteve fechada às inovações estéticas, ainda que seja plenamente reconhecível dentro do campo modernista e depois propriamente moderno. Bandeira soube preservar as demais influências e resgatá-las quando assim julgasse necessário. E, como afirmou Yudith Rosenbaum, essa volta constante é ainda "a essência de sua relação com a própria experiência de vida, que nunca perderá seu lugar na memória" (2002, p. 24).

Para o crítico Roberto Vecchi, a elaboração do código poético bandeiriano atravessará de viés a tradição "numa operação de inscrição do novo experimental no velho experimentado" (VECCHI, 1996, p. 292), como uma espécie de acolhimento das produções literárias anteriores que contribuíram para a formação da arte moderna. A partir desse "novo experimental", também mantiveram-se vivas, ao longo de toda a formação intelectual de Bandeira, suas relações com a cultura oral e popular de sua infância em Recife, como meio para a ampliação das questões temáticas, formais e rítmicas, associadas à dialética da tradição/inovação na qual se combinam, não só por oposições e contrastes, elementos fragmentários da modernidade.

Dessa forma, os dois primeiros livros podem ser considerados como obras que se articulam de forma mais direta com a época em que surgiram, onde se desfaziam tendências mais delimitadas e, ao mesmo tempo, ainda não se haviam definido bem outras perspectivas. De acordo com Julio Castañon Guimarães, para esse período tem se empregado o termo pré-modernista, "que tanto pode ter uma significação cronológica, como se referir a uma produção com características comuns que já antecipassem o modernismo" (2008, p. 90).

Não podemos deixar de notar, contudo, o predomínio dos traços parnasianos e simbolistas no seu primeiro livro $A$ cinza das horas. Numa crônica bem posterior a essa época, intitulada "Gralhas", publicada na reedição de Flauta de papel, Bandeira se refere a seus "tempos de iniciação parnasiana". A partir dessa referência, ele nos remete a cuidados especiais com o vocabulário, com o emprego de vocábulos de uso não frequente e 
considerados próprios para a poesia, além de uma atenção quase natural às normas estritas da versificação, como a métrica e as rimas. O zelo com a forma persistirá em sua obra modernismo adentro, pois para Bandeira o verso livre nunca sobrepôs o rigor construtivo de seus versos.

Bandeira logo se desvencilhará dos efeitos estéticos trabalhados a partir da escola parnasiana, porém a influência simbolista terá uma permanência mais duradoura, principalmente por trazer a aspiração de uma "existência totalizadora", assim como veremos em Laforgue. O que para ele será fundamental nos grandes simbolistas - em suas leituras, entre várias obras, a de Laforgue - é o imenso arsenal metafórico, ideal para "fazer da poesia uma questão de sensações e emoções do indivíduo" (WILSON, 2004, p. 61). Para o crítico Edmund Wilson, esse movimento resgata os princípios mais recônditos da interioridade humana (não assimiláveis pelos preceitos da ciência) e é onde o poeta deve inventar uma linguagem capaz de abarcar esse novo universo.

Seus símbolos devem "comunicar percepções únicas e pessoais", expressando o que é "fugidio e especial". A mimese realista é então substituída por um universo ilimitado de representações, em que a linguagem destrona a realidade e assume o papel principal. Veremos mais adiante como Jules Laforgue sedimentou esses preceitos em sua poesia, já que sua produção esteve inserida nesse quadro do final do século XIX.

Se tudo isso já estava presente nos textos românticos, agora o império sensorial e emotivo atinge seu grau máximo. Todas as possibilidades se encontram no espaço privilegiado da linguagem, representando assim um "ideal de renúncia a experiência do mundo exterior, em prol da experiência imaginativa tão somente" (WILSON, 2004, p. 187). A palavra para os simbolistas transforma-se na "experiência desfrutada na solidão" e esse desligamento do poeta em relação ao mundo exterior o conduz a uma atitude de indiferença e não de hostilidade à sociedade industrial da época.

Todas essas características são facilmente encontráveis nos primeiros versos de Bandeira, pois de fato, seus três primeiros livros estão mais intensamente ligados à tríplice estética do parnasianismo, simbolismo e crepuscularismo. Porém, sabemos que essas vertentes poderão ser 
encontradas na obra posterior do poeta, de forma renovada. Podemos relacionar esse aspecto mais duradouro na obra de Bandeira com o "o grande tema central do Simbolismo", que foi, de acordo com Anna Balakian, "a luta do homem contra o vazio, ao visualizar o poder da morte sobre a consciência" (BALAKIAN, 1985, p. 126). Assim, ao longo de sua produção, Bandeira retomará a temática da morte em diversas facetas, unindo ao visionarismo simbolista a dimensão de sua própria finitude. E a iminência da morte no dia a dia deixa de ser apenas um tópico da estética simbolista, passando a ser parte integrante da poesia de Bandeira. Para Yudith Rosenbaum, "é nela que o nosso poeta se reconhece à medida que a vivência da falta se corporifica na vida e na obra, recriando um tema do fim do século dentro de um entorno já totalmente modernista" (ROSENBAUM, 2002, p. 27).

Além da influência permanente do simbolismo na tonalidade bandeiriana, vale fazer aqui um breve comentário sobre a influência crepuscular. O crepuscularismo é uma vertente que marca, na segunda década do século $X X$, a transição entre o simbolismo e o modernismo. Para Norma Goldstein,

Mais tendência poética do que grupo propriamente dito, ele se caracteriza por uma melancolia agridoce, pelos temas ligados ao cotidiano, por uma morbidez velada - atitude doentia de perplexidade em face do progresso e da técnica, traduzida, no plano afetivo, por uma atenuação dos sentimentos. Paralelamente, os poetas crepusculares praticam a desarticulação do verso por via do ritmo dentro da métrica tradicional, chegando a modificá-la. Poderíamos falar, portanto, num processo de meiotom formal correlacionando a um processo de meio-tom psicológico. (GOLDSTEIN, 1983, p. 5)

O que é válido é que nem todos os elementos dessa estética de transição foram absorvidos por Bandeira. Em Carnaval, nosso poeta já anuncia a ruptura com o lirismo lânguido e intimista dos crepusculares, em busca de ritmos breves e mais "brasileiros". Mas o que realmente foi incorporado, além da temática que ditava a época - morte, solidão, melancolia, noite -, foram as formas da representação subjetiva de Bandeira, como as de natureza confessional, que marcaram sua obra de maneira inconfundível. 
Vale ressaltar que, além da forte indicação da perspectiva confessional de seus versos iniciais, marcados por essa densa tonalidade emotiva, vários dos temas de caráter pessoal e as várias abordagens intimistas encontradas em $A$ cinza das horas serão sedimentados e retomados ao longo de toda a sua obra, tratados naturalmente de acordo com novas concepções.

Em parte, esse aspecto contribui para explicar a qualidade da realização dos poemas de seu primeiro livro e como eles ultrapassam os limites estritamente pessoais. Tudo isso se dá porque, como observou Castañon, em A cinza das horas, "os poemas de natureza confessional escapam do que poderia ser meramente circunstancial, adquirindo uma outra dimensão, mais ampla" (CASTAÑON, 2008, p. 67).

Além do virtuosismo técnico, nesses poemas há uma fluência e limpidez que na maioria dos casos o poeta harmoniza com os elementos constitutivos do texto como, por exemplo, em "A minha irmã". Neste poema, em que o poeta se dirige a irmã - agradecendo por sua solicitude -, encontramos um diminutivo ao final que poderia talvez soar excessivamente sentimental; mas o conjunto harmônico e estruturado de todos os componentes do poema impede essa possibilidade:

$[\ldots]$

Por isso eu te amo, e, na miséria minha,

Suplico aos céus que a mão de Deus te leve

E te faça feliz, minha irmãzinha...

É essa mesma habilidade que veremos manifestada em outros planos, como no do ritmo, o que se pode ver num poema como "Poemeto erótico". Escrito em redondilhas maiores - versos de sete sílabas, de longa tradição na literatura luso-brasileira, inclusive de origem popular -, o poema não apenas tem como tema o erotismo, mas também o faz surgir em sua própria construção. Fala de um corpo, e o faz por sucessivas comparações, sobretudo com elementos perceptíveis pelos sentidos:

[...]

Teu corpo é tudo o que cheira... 
Rosa... flor de laranjeira... ${ }^{4}$

[...]

O dado erótico não se encontra apenas nesse sensualismo. Encontrase no ritmo, entendido este de forma mais abrangente, e não apenas como contagem de sílabas. A comparação, que vem a ser uma forma de descrição, funciona também como forma de apreensão. Desse modo, um sensualismo generalizado, em que coisas variadas são associadas ao corpo, se instala por meio do processo de enumeração. O corpo se materializa no próprio poema, conforme a primeira declaração que se lê na primeira estrofe: "Quero possuí-lo no leito/ Estreito da redondilha". Isso se dá em períodos breves e em estrofes curtas, havendo algumas de apenas um verso, compostas como que de definições sumárias do corpo.

Esses detalhes já são o indício da complexidade do poeta Manuel Bandeira, que soube como ninguém conjugar elementos de estéticas da época com suas marcas próprias. Assim como observou Sergio Buarque de Holanda, "para o poeta de $A$ cinza das horas, tudo existe em função da própria experiência" (HOLANDA, 1980, p. 146). Desde o início há, então, certa "liberdade" que ora estava presente na sua habilidade com as palavras e o universo da poesia, ora nas suas reminiscências e experiências pessoais.

Essa versatilidade é uma das razões que tornam a apresentação de sua obra um desafio para os estudiosos. Comparada ainda a de outros autores, como no nosso caso, com a de Jules Laforgue, que também por sua vez recebeu a influência de tantas outras vertentes, é possível dizer que Bandeira, por sua extensão de tempo vivida, soube aproveitar ainda mais e adensar em sua poética os limites e as amplitudes de todas as suas influências. Segundo Davi Arrigucci Jr., a obra de Manuel Banderia pode ser considerada uma "mescla estilística inovadora e moderna, uma vez que persegue uma elevada emoção poética através das palavras mais simples de todo dia" (ARRIGUCCI, 2009, p. 15).

E essa mescla inovadora está inscrita sob a abertura ideológica na qual Banderia se permitiu ao adentrar na guinada modernista. A geração de 22 é

\footnotetext{
${ }^{4}$ Trecho extraído do poema "Poemeto erótico", in A cinza das horas, 1917.
} 
motivo de entusiasmo para o poeta de trinta anos, que viu na ruptura contra a rigidez métrica, na mensagem coloquial, prosaica, múltiplas possibilidades linguísticas.

Bandeira se entrega ao movimento modernista acompanhando, até certo ponto, o que ele representa de destrutivo (ao demolir as estruturas estagnadas e anacrônicas da linguagem "oficializada") e construtivo (redescobrindo um Brasil oculto pelo verniz academicista e experimentando linguagem e temas novos. (ROSENBAUM, 2002, p. 31)

É, então, a partir dessa entrega que o poeta pernambucano surpreende: não abandona por completo as características consideradas "passadistas", mas adere ao verso-livre (e assim como no caso de Laforgue na França, é o pioneiro no Brasil) e à descoberta do cotidiano com a mesma profundidade com que cultivou as heranças clássicas, simbolistas e crepusculares. O espírito modernista oferece a Bandeira as ferramentas necessárias para ampliar o caráter estritamente melancólico de sua lírica iniciática, "servindo-se dos elementos mais libertadores para anistiar a si mesmo".

A linguagem passa a não ser mais o lugar exclusivo para a sua reconciliação com o mundo; agora Bandeira incorpora abertamente o caráter cotidiano como sustentação de sua trajetória. Ou seja, é através da realidade amarga e repleta de alumbramentos que o poeta escapa da vivência de uma "dor enclausurada", para respirar nos ares do humor, da ironia, dos sonhos e "da vivacidade de, afinal, ter sobrevivido" (ROSENBAUM, 2002, pp. 31-32). É assim que um texto como "Andorinha, andorinha" recria o canto da dor a partir de um dado do cotidiano humilde do poeta, de forma surpreendente:

Andorinha lá fora está dizendo:

- "Passei o dia à toa, à toa!"

Andorinha, andorinha, minha cantiga é mais triste!

Passei a vida à toa, à toa... ${ }^{5}$

\footnotetext{
5 “Andorinha”, in Libertinagem, 1930.
} 
A experiência pessoal, fortemente carregada pela dor e pela eminência da morte, se viam presentes no cotidiano do poeta que, aos poucos, econtrou alicerces mais sólidos para transformá-la em sabedoria. Esse confronto com as palavras se fez necessário não apenas para tornar possível a passagem para a auto-observação, mas também Ihe permitiu uma nova possibilidade de dizer o que não era fácil de ser dito, ressignificando assim seu mundo.

Porém isto não equivale a dizer que a poesia de Manuel Bandeira perdeu sua qualidade estilística e que abandonou os grandes temas existenciais, apenas que o seu método e a sua cultura, muitas vezes assumidamente popular, passam a favorecer de forma interessante esse novo sopro criativo. As variações notadas nos seus poemas, no que diz respeito às oscilações de sentimento, a riqueza musical da sua frase, as felizes e novas associações de adjetivos revelam o trabalho conjunto da inteligência e da intuição.

O curioso é que, diferentemente de poetas considerados canônicos na poesia moderna como Baudelaire, Mallarmé, Rimbaud e Verlaine - dos quais Laforgue foi herdeiro mais direto -, a poesia de Bandeira não trará a maior parte das características próprias a esse contexto. Assim como afirma Hugo Friedrich, em seu importante livro sobre a lírica moderna, as obscuridades, as categorias negativas, bem como a incoerência e as deformações não são detectadas na poética bandeiriana.

Opostamente a Laforgue, a aniquilação dos objetos e a sua elevação ao absoluto, subsistente apenas na linguagem original e que "nada mais tem a ver com poesia de sentimento, poesia de vivência, poesia de experiência" (1978, p. 101) não é característica da poesia de Bandeira.

Para nosso poeta, o alumbramento sempre poderá surgir no mais humilde cotidiano, de onde o poético possa ser desentranhado à força da depuração e da condensação da linguagem, na forma mais simples e natural do poema, como nos mostrou tão bem Arrigucci Jr. Porque sua poesia, independentemente das influências, ultrapassa as regras, "transfigura o que é universal e anônimo em uma criação pessoal incessante" (HOLANDA, 1980, p. 157). 


\subsection{Jules Laforgue: Simbolismo e decadentismo na França do final do século XIX}

Para traçarmos uma linha paralela entre as obras de Manuel Bandeira e Jules Laforgue precisaremos voltar ao início da trajetória do poeta francês e recuar à segunda metade do final do século XIX na França. Optamos por fazer aqui um movimento anacrônico para dar destaque ao poeta brasileiro e manter a linha de comparação sempre em relação à obra bandeiriana.

Assim como comentamos acima, igualmente difícil é fazer a apresentação da obra de Jules Laforgue. Coincidentemente, a dificuldade maior converge para o mesmo ponto destacado em Bandeira: a versatilidade ou a influência de várias vertentes fazem da obra de Laforgue uma incógnita, por muito tempo esquecida pelos críticos e leitores.

É provável que essa indecisão em relação ao "encaixe" de sua produção poética dentro das escolas literárias no final do século XIX francês tenha corroborado para o longo silêncio no qual seus escritos foram condenados. Mas hoje sabemos que a determinação de certos preceitos ou ainda a insistência em adequar uma obra a uma escola já não faz mais tanto sentido. Sobretudo quando se trata de uma obra absolutamente moderna, concebida durante a revolução lírica de autores como Baudelaire, Mallarmé, Rimbaud e Verlaine.

Foi assim, após quase quarenta anos de sua morte, em 1924, com a publicação do primeiro grande estudo sobre a vida e a obra de Jules Laforgue por François Ruchon, que os críticos passaram então a reconhecer sua importância para a poesia e para seus leitores. De certa maneira, talvez por ser contemporâneo a Baudelaire e Mallarmé, por exemplo, os críticos da época não se dedicaram à qualidade artística que hoje inseriu Laforgue entre os grandes nomes da modernidade poética. Sua originalidade demonstrou características que ultrapassam as classificações do Decadentismo e do Simbolismo. Seus escritos surpreendentes e inovadores é que fazem dele o inspirador, além de Manuel Bandeira, de poetas como Ezra Pound e T. S. Eliot.

É dessa forma que muitos historiadores, autores de antologias e críticos literários o enquadram aleatoriamente dentre os poetas simbolistas ou 
decadentes e, muitas vezes, concordam entre si quando o consideram um dos "iniciadores" ou "precursores" do "movimento simbolista". François Ruchon é bastante direto nesse sentido. Ele acredita que "a obra de Laforgue coincide em todos os pontos com as principais tendências do simbolismo" (1924, p. 223).

Mas antes seria preciso entender quais foram essas tendências e o que foi o movimento simbolista mais aprofundadamente. O mistério, a angústia metafísica, o pessimismo, o sonho são elementos exclusivos da poesia simbolista? Não são características também da escola romântica ou parnasiana? Mas, para Ruchon, a "problemática do símbolo" [le souci du symbole] só pode ser encontrada exlusivamente nos poemas de Laforgue.

Para darmos início à compreensão dessas tendências, que foram não só influenciadoras da obra de Laforgue e sim fizeram parte do arcabouço literário de Manuel Bandeira, faz-se necessário, neste momento, discorrermos brevemente a respeito da modernidade literária. Para muitos teóricos, sua concepção provoca muitas divergências; contudo, talvez a maioria siga a tendência de definir o seu começo no século XVIII, em razão das inúmeras mudanças e inovações que ocorreram nessa época, de projetos de reforma social à criação de utopias, somados à revolução científica e à filosófica. Segundo Octavio Paz, a gênese da modernidade se inicia com questionamentos à religião, à moral, à filosofia, ao direito, à história e à política, apresentando a crítica como um traço marcante e diferencial.

O Romantismo será a grande negação dessa modernidade concebida até então. A ideia de modernidade é recriada pelos românticos, trazendo a visão das correspondências, as quais serão apresentadas, mais tarde, por Baudelaire. Para o desenvolvimento desse novo conceito de modernidade, a ironia e a dissonância serão recursos fundamentais, os quais serão trabalhados minuciosamente nas obras de Jules Laforgue e, mais adiante, na obra de Manuel Bandeira, de forma autêntica e inovadora.

Com a escola Romântica e, em seguida, com o Simbolismo, o século XIX vai refletir o apogeu dessa modernidade, preparando cuidadosamente 0 terreno para os movimentos de vanguarda. É nesse final de século que a crise da representação torna-se central, uma crise ética e, sobretudo, estética, que estimula à produção de algo absolutamente novo, fruto da destruição dos 
parâmetros que norteavam o pensamento há séculos. A partir disso, a busca pelo original incentiva os artistas a ensaiarem combinações inusitadas, valendo-se da completa falta de padrões.

É nesse âmbito que surge o primeiro dever do artista moderno: o de emancipar-se, fugir dos padrões e dos cânones literários. Jules Laforgue irá além: utilizará as rupturas acima citadas com o objetivo de realizar e validar a ironia, base de sua obra e também a do Simbolismo, segundo Bradburry e McFarlane, quando observam que "o simbolismo traz em si a passagem de uma estética romântica para uma estética modernamente irônica" (BRADBURRY \& McFARLANE, 1989, p. 166).

Laforgue tentará atingir a originalidade, criando uma linguagem própria, distinta, refinada e clownesca. São esses elementos que poderemos também observar na poesia de Manuel Bandeira, pois em ambas as obras, muitos poemas transfiguram uma melancolia incessante, ligada ao dia a dia, ao cotidiano, à nostalgia incurável da vida, como o spleen baudelairiano, mas sem deixar de lado o humor.

Mas, antes de falarmos estritamente do Simbolismo, ainda é preciso definir o Decadentismo, movimento anterior, porém com teor mais negativista. De acordo com Henri Peyre, nas últimas décadas do século XIX, a literatura simbolista prezou todo o cansaço da vida, o langor, o isolamento em relação à sociedade tecnológica, considerada materialista. Por isso, muitos teóricos denominam os escritos que contêm tais características como "decadentistas", ou seja, elaborados pelos "decadentes", termo existente para denominar escritores adeptos do pessimismo e da decadência iminente.

O homem decadente é aquele que surge, segundo Álvaro Cardoso Gomes (1976), dentro de uma grave crise do final do século XIX. A Revolução Industrial que acontecia nessa época favorecia situações como o inchasso das cidades, a dúvida quanto aos métodos científicos, a sensação de que a sociedade se tornava cada vez mais materialista, provocando, assim, o sentimento negativista. O pessimismo da época ressalta o homem "decadente", aquele que se sente à parte da sociedade, que se isola em sua torre de marfim e que busca impressões mais refinadas. 
Para Fulvia Moretto (1989) há, nesse momento, uma contradição: a geração de 1880 é abraçada por um frio de decadência e de morte, mas almeja algo diferente, a renovação dos conceitos. Instaura-se uma luta contra as escolas parnasiano-naturalista e contra o academismo poético. E, então, o Decadentismo prossegue na linha do idealismo.

Esta tendência nasce com Joris-Karl Huysmans e seu romance $\grave{A}$ Rebours [Às avessas], publicado na França em 1884, considerado hoje a bíblia da estética decadentista. O romance, além de captar a alma decadente da época, sonda os abismos do ser por meio de uma linguagem minuciosa e elaborada. O protagonista, Des Esseintes, sentia profunda irritação pelo classicismo e atração pela extravagância, pelo requinte e pelo exótico. Seus interesses eram o barroco, o artificial, as quintessências do latim, os anagramas e epigramas. Excêntrico, Des Esseintes era tomado por um enorme tédio, gerado pelo exagero e reflexo da filosofia de Schopenhauer. Buscando fugir desse estado de spleen, seus prazeres serão cada vez mais priorizados através de sinestesias ousadas, de detalhes minuciosos do olfato e das aventuras eróticas, movidas pelo instinto.

O personagem de Huysmans torna-se símbolo do homem decadente, por seu gosto pelo perverso, aberratório, pela visão moderna de uma arte refinada e pela reclusão: afasta-se da convivência humana para viver seus desejos e caprichos não compreendidos, traço comum entre os decadentistas e simbolistas, ilustrado por várias passagens de À Rebours. Embora rejeitando a sociedade de sua época, Jules Laforgue seguiu por um caminho inverso: para criticar aquilo que não aceitava, permaneceu em meio às pessoas e recriou a poesia ao invés de se isolar em convenções poéticas. Esse é um dos motivos pelos quais os teóricos também insistem em classificá-lo como simbolista.

Em abril de 1886, Anatole Baju funda o jornal Le Décadent Littéraire et Artistique e publica o manifesto Aux Lecteurs. Gilberto Mendonça Telles afirma que o movimento decadentista terminaria três anos depois, confundindo-se, portanto, com o Simbolismo. Apesar de muitos simbolistas terem nascido em meio aos parnasianos, o Simbolismo se opõe ao Parnasianismo pela busca por uma renovação. O movimento foi um sopro de liberdade, corroborando com a ruptura na tradição vigente; teve a música como grande influência e aliada, 
sendo Wilhelm Richard Wagner, compositor alemão, o nome de maior relevância. A influência de Wagner foi tão importante quanto a de qualquer poeta, pois a música teve papel bastante significativo no movimento, devido ao desejo dos simbolistas de elevarem a poesia à condição de música, considerada a mais subjetiva das artes.

O subjetivismo é um traço marcante na poesia simbolista, além da indefinição que, desde Edgar Allan Poe, revela a verdadeira expressão musical. Para os escritores, fazia-se necessário o encontro com o "eu" mais profundo, um "eu" diferente do romântico na medida em que não era envolto por sentimentalismos, era o "eu" mais interior e o mais secreto que podia existir. Edmund Wilson lembra que, algumas vezes, os simbolistas fizeram da poesia algo tão privativo do poeta, que ela se tornou incomunicável ao leitor.

Os românticos também tiveram uma forte influência sobre 0 movimento, sobretudo Poe, bastante apreciado por Baudelaire. Mas, vale lembrar que, apesar de o Simbolismo ter suas raízes no Romantismo, não podemos considerá-lo como um mero prolongamento, mas sim, uma outra faceta do espírito romântico. Entre 1885 e 1895, o movimento simbolista cresceu na França, quando diversos manifestos, revistas literárias como La Vogue, Revue Indépendante e La Décadence foram publicados, e Paris foi invadida por poetas e literatos de todo o Ocidente. Os escritores franceses de grande renome do século XIX, Baudelaire, Verlaine, Nerval, Rimbaud e Mallarmé podem ser considerados antecipadores do movimento, pois já apresentavam em seus escritos, antes mesmo que o Simbolismo surgisse, características que seriam caras a esta geração.

O simbolismo espalhou-se pela Europa, Ásia e América no século XX, como bem aponta Anna Balakian (2000). O culto ao mistério, a tudo que é vago, o indizível, o sonho, o invisível, as "torres de marfim", representam artistas que se sentem à margem da sociedade, pois não encontram nela o seu lugar; por isso, agem como dandys, abalando a sociedade por sua maneira irreverente de se portar ou de se vestir. O cromatismo, a sonoridade e o impressionismo são extremamente usados para tornar sua poesia mais subjetiva. Ao invés de dizer, sugerem e anseiam ser decifrados por seus leitores, pois o poeta deve ser um vidente, deve ser agraciado com o dom de 
captar os segredos ocultos em meio aos símbolos, à maneira do que se lê no poema "Correspondances" de Baudelaire.

O Simbolismo pode ser considerado, então, como um estilo, e sua denominação tem origem no vocábulo "símbolo". A propósito do uso dos símbolos, Anna Balakian cita Maeterlinck, que os definiu como "efetivos" e "artificiais". O primeiro traz um aspecto humano à abstração, aproximando-se da alegoria; o segundo, de caráter inconsciente, transcende o pensamento do poeta e, ao ser utilizado, demonstra a genialidade do escritor. A esse respeito, Balakian ainda afirma:

Todos estes símbolos sugerem, com diferentes graus de intensidade, o desejo de fugir, não para uma nova morada, mas para longe de um lugar que é desagradável ao espírito poético (BALAKIAN, 2000, p. 87).

E é sobre esse mesmo "desejo de fugir" que as poéticas de Jules Laforgue e Manuel Bandeira se encontram muitas vezes. A subjetividade desenvolvida pelos dois poetas é que dará caminhos distintos a essa fuga.

Vale mencionar ainda que o Simbolismo teve, na verdade, duas vertentes. Uma delas, a "coloquial-irônica", segundo denominação de Edmund Wilson, é representada por Laforgue e Corbière e é menos estudada. Para Michael Hamburger (2007), estes dois escritores atualizaram em seus poemas a obra inicial de Rimbaud e, ao mesmo tempo, o spleen e o idéal de Baudelaire. Diferentemente da vertente "sério-estética" do Simbolismo, descrita anteriormente, os "coloquiais-irônicos" não visavam dar um sentido mais puro às palavras; ao contrário, pretendiam provocar o confronto entre as torres de marfim e a sociedade fin de siècle, porque se preocupavam com o cotidiano e o tematizavam.

Veremos que tal preocupação com o cotidiano é um dos elementos que farão a ponte de ligação entre a poesia de Jules Laforgue e Manuel Bandeira. Aqui, lançamos uma de nossas primeiras questões: não seriam pelos caminhos "coloquiais-irônicos" do Simbolismo que Manuel Bandeira, como poeta culto e "descobridor" de tendências, de fato se embrenhou para absorver em sua poesia o despojamento linguístico e uma especial habilidade para com a ironia? 
Sem dúvida alguma é nesta vertente que se pautam os recursos usados na poesia de Laforgue. Sua escrita inovadora une aquilo que parece ser incompatível, radicalmente diferente (se levarmos em consideração aquele momento histórico): o lirismo e o humor. Além disso, a alegoria, a paródia, a caricatura e o pastiche são utilizados com o propósito de dar um efeito dissonante aos seus poemas, apresentando um ideal poético que perpassa 0 discurso clownesco, autêntico e minucioso.

Sobre a dissonância, Friedrich afirma ser ela a "junção da incompreensibilidade e da fascinação, gerando tensão, objetivo visado nas artes modernas em geral, não somente na lírica" (FRIEDRICH, 1978, p. 66). A obscuridade originada de seu uso é intencional, pois a dissonância não anuncia e nem prepara o leitor, surpreende-o. Friedrich supõe ainda que na poesia moderna há a pretensão de se tornar autosuficiente, abrindo-se para amplas significações desde o entrelaçamento de tensões, até a criação de universos distintos ou divergentes. E, para esse fim, resgata-se o arcaico, o místico e o oculto, emparelhando-os com a simplicidade do cotidiano.

Jules Laforgue, além de construir imagens dissonantes, mantém, em inúmeros poemas, uma métrica precisa e com rimas ricas, traços que o ligam ao parnaso e ao simbolismo; não obstante, a escolha pela forma marcada levao mais a criticar tais tendências do que a exaltá-las, visto que ele utiliza o ritmo em conformidade com a temática escolhida, a exemplo de suas Complaintes, uma invocação recitada ou cantada, repetitiva, entediante e monótona, repleta de queixas e pedidos. Os recursos que Laforgue utiliza não são, muitas vezes, originais; a forma como o poeta os emprega é que difere do usual. Nesse caso, nada melhor do que versos curtos e rimados para descrever essa atmosfera, como em "Complainte de l'oubli de morts":

[...]

Importun

Vent qui rage ! 
Les défunts?

Ça voyage...6

$[\ldots]$

Contra o passadismo, ao longo de sua obra, Laforgue desenvolverá e aprimorará seu verso livre, para falar do sonho, permeando assim, o ideal e o inconsciente, inspirado pelas teorias de Schopenhauer e de Hartmann. O "je" se coloca em confronto com a natureza, assim como o sujeito e o discurso, por meio da linguagem. Para Henri Scepi, o "je" de Laforgue é construído por cada palavra proferida, pela linguagem e o enigma eterno de suas próprias contradições.

Conforme afirmou Daniel Grojnowski, de acordo com a filosofia de Hartmann, "tudo pode ser explicado pelo inconsciente, o qual é incondicionado e absoluto, o criador do universo, não sendo possível explicá-lo por meio de nenhuma relação" (GROJNOWSKI, 1988, p. 68). Para Hartmann, perder-se no inconsciente é uma alegria, assim como a ideia da fatalidade, do desejo de não viver e da renúncia ao individualismo. Sua teoria foi calcada nos ideais de Schopenhauer, Hegel, Schelling e Nietzsche, postulando uma concepção niilista de que retornar ao nada é mais válido que viver. Já Schopenhauer, conhecido como o filósofo do pessimismo, via o mundo como uma piada de mau gosto, indiferente ao destino do ser humano.

Defendia que o mundo "visível" seria uma espécie de representação apoiada em uma Vontade universal cega e, por essa contradição, provocaria miséria, sofrimento e morte. A única maneira de escapar do individualismo contido nessa Vontade seria a compaixão pelos irmãos, obtida através da renúncia, a abnegação da vontade e o culto às obras de arte. Para ele, uma possibilidade de ver além do mundo das aparências seria olharmos para o nosso "eu" mais profundo.

Em acordo com estas filosofias, o poeta, na medida em que é movido por uma força que ultrapassa seu entendimento, é então considerado um gênio; a poesia nasce como uma intuição, livre de toda intenção consciente.

\footnotetext{
${ }^{6}$ Tradução nossa: Se não há piedade/ Ela virá (sem rancor)/ Lhe agarrar pelos pés, / Em uma noite de lua cheia!// Importuno/ Vento que sopra!/ Os defuntos/ Esses vagam...".
} 
Alguns poemas de Laforgue revelam o apreço pelo pensamento niilista de Schopenhauer, sobretudo os que tratam de temas como a dor do mundo, a morte, o amor não correspondido, a religião, o livre arbítrio e as tensões entre o homem e a sociedade. Daniel Grojnowski, a respeito das teorias de Hartmann, lembra que o inconsciente estaria diretamente ligado à criação artística, pois apenas o artista verdadeiro é capaz de produzir uma obra original no momento da inspiração - exclusiva ao artista -, e a sua prática.

Mesmo sem compreender perfeitamente o sentido do que está criando, o trabalho do artista é o de transmitir as ideias sem a intenção de que estas sejam completamente interpretadas. Como uma terra desconhecida, o inconsciente é uma espécie de Pasárgada onde Laforgue também deseja viver, guardadas as devidas proporções. ${ }^{7}$ Dessa maneira, instaura-se uma língua sem sintaxe, um código repleto de imagens exóticas, relatos oníricos e hipnóticos, tocados pela oralidade. Isso justifica, de acordo com Michael Hamburger, "a recorrência da oralidade na poesia de Jules Laforgue, aliada ao gosto pela bufonaria verbal" (HAMBURGUER, 2007, p. 237).

Em Laforgue, o inconsciente surge como força, lugar e palavra. A estrutura verbal de seus poemas revela um procedimento análogo a um trampolim de ideias e signos, vinculando o poema escrito à representação da voz humana, a união entre o ser e o dizer. Laforgue aspira a uma palavra liberta de todo modelo ou padrão, produzindo versos originais para criar um novo modo de dizer, polifônico e carnavalesco, livre, acima de tudo, de qualquer vertente estética do passado, do presente ou do futuro.

\footnotetext{
${ }^{7}$ Comparando aqui a Pasárgada mais radical de Laforgue, onde se suspendem todas as leis e regras da existência comum com a de Bandeira, um contraponto ao menino doente.
} 
CAPÍTULO 2 | A CONSTRUÇÃO DA MATÉRIA IRÔNICA 


\section{1 "A própria dor é uma felicidade":8 Manuel Bandeira}

Para Manuel Bandeira o ato de escrever teve papéis distintos ao longo de sua vida e em seu amadurecimento poético. Tornou-se parte do seu dia a dia ainda muito cedo, antes mesmo de afirmar-se poeta. Para ele, no início, os versos eram uma forma de distração de um aluno dedicado que usufruía de seus conhecimentos literários para passar horas estudando técnicas de versificação.

Porém, acontecimentos decisivos em sua vida, como a descoberta da tuberculose, obrigaram Bandeira a encarar a escrita como meio que o salvaria do tempo ocioso, do peso das horas sem ter como sair da cama. Nesse exercício ou passatempo, nascia ali a poesia como meio de reflexão, ferramenta indispensável para superar o obstáculo imposto em sua juventude.

Vejamos em uma passagem de Itinerário de Pasárgada como Bandeira relata o início de sua experiência com os versos a propósito de seu livro de estreia, A cinza das horas:

Nada tenho para dizer desses versos, senão que ainda me parecem hoje, como me pareciam então, não transcender a minha experiência pessoal, como se fossem simples queixumes de um doente desenganado, coisa que pode ser comovente no plano humano, mas não no plano artístico. (BANDEIRA, 1984 [1954], p. 57)

Mas, para Mário de Andrade, o encontro do poeta com a tuberculose foi uma "data histórica":

Manuel se retirou da vida. O observador virou contemplativo. E tudo contou em função de sua realidade interior. Aquela umidade febril da tísica

${ }^{8}$ Verso extraído do poema XVII do livro Losango cáqui, de Mário de Andrade, publicado originalmente em 1922. Vale a pena mencionar que, numa carta datada de 5 de agosto de 1923, antes de revelar os versos ao amigo Manuel Bandeira, Mário de Andrade comenta: "Não sou infeliz, embora sofra às vezes. Se rio no palco é para melhor observar as plateias. [...] Também sou alegre. Digo mais: não só me penso, mas me sinto um homem muito feliz: porque para mim a dor cabe perfeitamente dentro do sentimento de felicidade. [...]". (ANDRADE [1923] apud MORAES, 2001, p. 99). 
se infiltrou por tudo e embolorou tudo. Um veludo silencioso amaciou a rigidez, a linha aguda, a reta crua da vida. A tuberculose pra Manuel Bandeira é que nem a campainha incessantemente sonora de certos cinemas de sessões corridas. Avisa que a gente pode entrar a qualquer hora na morte. Por isso não foi apenas motivo pra alguns versos esparsos nos poemas. É o urucu que the condimentou a obra inteira (ANDRADE, 1987 [1924], p. 73).

É dessa atitude contemplativa então que o poeta evoca na palavra lírica os sentimentos de dor e solidão iniciais. Aparentemente, os primeiros poemas de Bandeira nos colocam diante de uma circunstância de ordem estritamente íntima e pessoal que, em contato com outros aspectos, se configura poeticamente. E essa relação entre a descoberta da doença e a poesia irá convergir em uma atitude humilde que permanecerá em toda a sua obra. Mas, apesar de humilde, não podemos deixar de reconhecer uma "sabedoria determinada", como muito bem observou Murilo Marcondes de Moura, em reconhecer e "circunscrever o espaço mais adequado para sua atuação de artista e de homem, e de extrair dali a melhor densidade possível" (MOURA, 2001, p. 17).

Desde o início, sabemos que a poesia de Manuel Bandeira esteve intimamente ligada à sua experiência pessoal, assim como Mário de Andrade observou: "[...] tudo contou em função de sua realidade interior". Este recorte atravessado pela individualidade tem origem em um ponto de vista bastante especial: do encontro entre a solidão e a solidariedade. A experiência da solidão profunda servirá, então, como meio solidário de reconhecer aquilo que é essencialmente nítido dentro do difuso, ou ainda, o simples dentro do complexo.

Traduzida num desejo de despojamento e redução ao essencial, tanto nos temas quanto na linguagem, a aparente "poesia menor" nos desconcerta com sua simplicidade difícil de entender. Bandeira não está isolado do mundo. Pelo contrário, na opinião de Alcides Villaça, o poeta, atento, "recolhe em imagens o que mantém com o seu próprio 'eu' a condição comum do singular" (VILLAÇA, 1987, p. 30). Assim, a escrita passa a ser 
uma atividade do espírito, em momentos de súbita iluminação, concretizada em obras feitas de palavras. E trata-se de uma poética centrada num paradoxo: o da busca de uma simplicidade que brilha oculto 0 sublime (ARRIGUCCI, 1987, p. 10).

Não podemos esquecer que isso se deve também ao fruto da experiência lírica pela qual Bandeira percorreu desde o início de sua atividade escrita. A década de 1920 foi um período decisivo para a constituição de uma atitude fundamental, a "atitude humilde", que marcará toda a obra posterior. Além das influências maiores, como vimos no primeiro capítulo, da lírica portuguesa, do simbolismo e do crepuscularismo. Aos poucos, o poeta reúne elementos dispersos nas tradições e em novas discussões artísticas e, num momento específico, próprio ao alumbramento bandeiriano, cristaliza-os e molda-os em seus versos através do exercício contínuo da linguagem, como forma de aprendizagem da expressão.

Da mesma forma, podemos notar que esse processo se assemelha à pratica de um "artesanato interior", que permite a modelagem da subjetividade e a sua relação com o mundo: "É como se o poeta tivesse criado uma postura receptiva, feita de modéstia e recolhimento, para agasalhar os fatos do mundo, a que respondem os poemas" (ARRIGUCCI, 1987, p. 12).

Talvez esse momento de alumbramento coincida com o tempo da "solidão essencial", tão cara aos homens em geral, mas que pertence naturalmente ao poeta. Vimos antes que esse isolamento não torna a obra distante do mundo exterior: é justamente no processo de solidão da escrita que a universalidade da palavra se torna possível.

Sobre este momento próprio da elaboração poética, Maurice Blanchot, em O espaço literário (1987), afirma que o ato de escrever representa a escolha pelo rompimento com o elo do comunicável, um ato que "retira a palavra do curso do mundo", ou seja, aquilo que transforma o significado comum em algo que não se pode dizer corriqueiramente ou sem esse "estado de transe". E, para que haja essa tensão entre o real e o transe, o poeta deve originariamente pertencer a um outro tempo: àquele da solidão essencial onde "parece olhar de maneira diferente os objetos do mundo usual, neutralizar 
neles o uso comum, torná-los puros, elevá-los por uma estilização sucessiva ao equilíbrio instantâneo onde se convertem em quadro" (BLANCHOT, 1987, p. 41).

Não seria através desse estado que Bandeira mantém sua "atitude de apaixonada escuta" (BANDEIRA, 1984 [1954], p. 17) diante do mundo? Uma vez que sua poesia se dá, por meio do alumbramento, no mesmo plano da materialidade do corpo, a experiência lírica subverte, então, a banalidade da existência, fazendo com que o lugar comum se transforme num "insólito mais real do que o real" e produzindo o "estranhamento do novo" (ARRIGUCCI, 1987, p. 13). A seu modo, Alcides Villaça observou que a solidão retratada nos poemas de Bandeira atua da mesma maneira em relação ao cotidiano "enganosamente familiar":

A solidão criadora de Bandeira projeta-se contra o mundo real da despersonalização e, sem expressamente opor-se a ele, acaba por dialetizá-lo através de um regime próprio: o da atenção concentrada. Este tempo da atenção ao detalhe sensível, da vivência absorvente e da expressão depurada - que o poeta não tem pressa em alcançar - é de natureza muito distinta da do tempo do cotidiano, que está sempre a incitar os nossos sentidos à experiência perdulária e indiferenciada. $A$ atividade poética, negando-o, ganha com isso seu aspecto crítico mais legítimo, ajudando-nos a resgatar as particularidades de um mundo que, enganosamente familiar, pode nos absorver em sua matéria difusa (VILLAÇA, 1987, p. 31).

Com efeito, sabemos também que presença desses temas "menores", relacionados ao cotidiano solitário e humilde do poeta também se deve às influências recebidas dos simbolistas e dos crepusculares italianos, nítidas em seus três primeiros livros, dos quais Bandeira absorveu muitas lições e soube, como poucos, expandi-las ao longo de sua obra. De acordo com o que vimos anteriormente, os crepusculares se caracterizavam pelo tom melancólico e pelos temas "menores", voltados ao mundo particular.

Para Norma Goldstein, a linha dessa tendência no Brasil se prende mais à Verlaine e, por consequência, pode ser considerada fruto do espírito "decadentista" do qual falamos a respeito de Laforgue. É a partir desse entrelaçamento histórico-literário que as bases da poesia de Manuel Bandeira e 
de Jules Laforgue se encontram em um determinante comum: o cotidiano. Porém, há divergências no tratamento dessa temática em ambos os poetas. Para Guy Michaud, por exemplo, Jules Laforgue foi o grande poeta do cotidiano, o único capaz de elevá-lo ao "plano cósmico" (MICHAUD, 1947, p. 273).

Ao contrário de Laforgue, Bandeira não poetiza o habitual a ponto de dignificá-lo. Seu trabalho está mais próximo da "despoetização". Não se trata, portanto, de elevar o que se capta no plano comum, mas sim "desentranhar o poético junto às circunstâncias em que o 'eu' se acha situado" (ARRIGUCCI, 1987, p.10). O que é um tanto complexo, pois, para Manuel Bandeira, a poesia não estará inscrita no "mundo da Lua", mas na terra dos homens, "no chão do cotidiano". Assim, as relações entre o "eu" e as circunstâncias sedimentam o eixo central da poesia de Bandeira.

Partindo dessa perspectiva de despojamento, acompanharemos o processo de construção do sujeito lírico bandeiriano, primeiramente dominado pela consciência de seu ofício e das técnicas da tradição poética, mas já com alguns aportes das técnicas e leituras contemporâneas, assim como veremos em todo $A$ cinza das horas. Para tanto, iniciaremos nosso estudo pelo poema "O inútil luar". Vejamos quais aspectos já se encontram prenunciados nestes versos:

É noite. A Lua, ardente e terna,

Verte na solidão sombria

A sua imensa, a sua eterna

Melancolia...

Dormem as sombras na alameda

Ao longo do ermo Piabanha.

E dele um ruído vem de seda

Que se amarfanha...

No largo, sob os jambolanos,

Procuro a sombra embalsamada.

(Noite, consolo dos humanos!

Sombra sagrada!) 
Um velho senta-se ao meu lado.

Medita. Há no seu rosto uma ânsia...

Talvez se lembre aqui, coitado!

De sua infância.

Ei-lo que saca de um papel...

Dobra-o direito, ajusta as pontas,

E pensativo, a olhar o anel,

Faz umas contas...

Com outro moço que se cala,

Fala um de compleição raquítica.

Presto atenção ao que ele fala:

- É de política.

Adiante uma senhora, magra,

Em ampla charpa que a modela,

Lembra uma estátua de Tanagra.

$E$, junto dela,

Outra a entretém, a conversar:

- "Mamãe não avisou se vinha.

Se ela vier, mando matar

Uma galinha."

E embalde a Lua, ardente e terna,

Verte na solidão sombria

A sua imensa, a sua eterna

Melancolia... $^{9}$

Em relação ao aspecto formal, o poema compõe-se de nove quartetos que se constituem de três versos iniciais em redondilha maior e um último trissílabo, em um esquema de rimas alternadas ABAB. Por ser a forma utilizada desde os trovadores até os dias de hoje nas cantigas de rua, a predominância

9 "O inútil luar", in A cinza das horas, 1917. 
dos versos octassílabos, alternados com os tetrassílabos, já comprova a influência do verso popular sobre a fase inicial de Bandeira. Todo o poema se constrói no presente do indicativo, trazendo ao leitor a visão de uma cena no exato momento em que ela está ocorrendo: "É noite."

Há um sujeito, portanto, que observa a noite e o seu arredor. Os elementos são descritos a partir de uma posição solitária desse sujeito isolado, imerso em uma imensa melancolia. Da invocação da noite o texto absorve as sugestões sensoriais: sonoras (ruído), tácteis (rio, árvore, seda), visuais (sombra). O sujeito está isento de qualquer tipo de "ação", exceto o olhar, reduzindo-se à natureza contemplativa do sentido: "Procuro a sombra embalsamada." Em contraste, a grande maioria dos verbos diz respeito às "ações" da noite e de outros personagens.

Nos três primeiros blocos, ele cuida da descrição da noite e daquele ambiente. É interessante notar como a paisagem descrita projeta os sentimentos do "eu" observador num lamento melancólico. Como agente contemplativo, encontra-se distante, numa atitude passiva diante da noite e das pessoas.

A tensão rítmica é acentuada, sobretudo, pelos sons anasalados, produzidos pelas sílabas longas, como em "sombria", "imensa", "ardente", "terna", "ermo", "Piabanha", "jambolanos" e "embalsamada". Os componentes apresentados contribuem para a composição dessa atmosfera: as sombras, as águas escuras e ermas do rio Piabanha, em Petrópolis, ou ainda os jambolanos, árvore de frutos negros. A impressão que temos, numa primeira abordagem, é a de que o poema se presta muito mais à caracterização do ambiente ou de uma atmosfera, traço ainda marcado pelas influências penumbristas e crepusculares de $A$ cinza das horas.

$\mathrm{Na}$ quarta estrofe a ação é atribuída ao primeiro personagem apresentado pelo sujeito: "Um velho senta-se a meu lado./ Medita." As aliterações do fonema /s/ (senta-se, seu rosto, ânsia) prolongam o instante em que o sujeito observa o outro a ponto de reconhecer em seu rosto a densidade de uma ânsia. O uso do advérbio - talvez - sugere que a condição do velho seja algo conhecido do sujeito lírico que, mesmo distante, já compartilhou dessa mesma ânsia: "Talvez se lembre aqui, coitado!/ De sua infância." $O$ 
adjetivo "coitado" também acentua o sentimento de compaixão e solidariedade diante do outro.

$\mathrm{Na}$ quinta estrofe, o primeiro verso traz a primeira quebra de expectativa do poema: "Ei-lo que saca de um papel...". Nesse instante, o sujeito se dá conta que a angústia do velho estava relacionada a algo do presente: " $E$ pensativo, a olhar o anel, faz umas contas...". Após essa primeira ruptura, o eu lírico muda imediatamente de foco. Observa, então, dois homens que passam: "Com um outro moço que se cala,/ Fala um de compleição raquítica." E sua posição afastada, observadora, é novamente ressaltada em um dos poucos verbos relacionados ao sujeito: "Presto atenção ao que ele fala: - É de política."

Esse último verso ressalta o viés atenuante do poema, em que o poeta introduz temas "menores" que causam a quebra de expectativa em relação ao que se espera, traduzindo a melancólica meditação do sujeito diante dos outros que compartilham daquela mesma noite. Ao introduzir o elemento "política" no poema, a monotonia e a solidão aumentam, fazendo com que o eu lírico redirecione seu olhar para outra cena. Afinal, diante de tamanha sombra, de uma imensa melancolia, o sujeito não compartilha de assuntos banais, corriqueiros aos outros homens.

Eis que duas mulheres passam. Na sétima estrofe, uma delas é descrita e comparada a uma estátua grega: "Em ampla charpa que a modela,/ Lembra uma estátua de Tanagra." Com esta comparação o tom se eleva, para que, no último verso, um enjambement introduza a grande ruptura, proferida pela voz feminina: "- Mamãe não avisou se vinha./ Se ela vier, mando matar/ Uma galinha."

Como vimos, toda a atmosfera do poema foi sedimentada nas bases da influência finissecular. Porém, quando o sujeito se utiliza da temática banal e "menor" dos outros personagens para compor sua expressão, notamos, em meio a uma profunda melancolia, um traço irônico e original, que propõe novas imagens, novos elementos para a construção poética em Bandeira. A imagem da "galinha" se torna dissonante em relação ao restante do poema, sobretudo pela circunstância violenta à qual está associada. 
Arriscaríamos dizer que esse traço se deve ao caráter da "despoetização" citado acima a respeito da poesia de Manuel Bandeira. Essa habilidade, já visível em seu primeiro livro, irá se aprofundar nas obras seguintes através de uma diversificação formal e temática.

Por fim, a última estrofe, praticamente igual à primeira, sugere um ciclo que se fecha: é então que o sujeito se funde com a Lua, tão isolada e distante quanto aquele que apenas observa. O advérbio "embalde" é atenuado pelos adjetivos "ardente" e "terna". Por sua vez, a melancolia é o laço que une o sujeito à Lua, mas ao mesmo tempo, é o mesmo elemento que o separa do restante do mundo.

Para finalizar, remontando ao título, a Lua se faz tão inútil quanto o sujeito que prossegue na "solidão sombria", na "sua imensa, a sua eterna melancolia". E esse "prosseguir" é - assim como o contraste da luz branca que atravessa a noite escura - reflexo de certa positividade de um eu que, embora solitário, triste e patético, sempre será agente de superação.

É, então, a partir da solidão extrema, que Bandeira conquista aos poucos a simplicidade para expressá-la, e que também faz parte de sua própria história de vida. E essa maneira simples de dizer ou o despojamento usado como recurso essencial de sua lírica, será a marca de uma poética que caminhará tão logo para uma positividade (a propósito de uma afirmação da vida). A expectativa constante da morte dá a cada minuto "um fôlego e uma natureza especiais em Bandeira: a 'preparação para a morte' é, no fundo, uma qualificação da espera como a mais pessoal das prontidões íntimas" (VILLAÇA, 1987, p. 31).

Vejamos em "Dialogue avant le lever de la Lune" ['Diálogo antes do nascer da Lua'], do livro L'Imitation de Notre Dame la Lune, como o sujeito lírico laforgueano reage à dor e a solidão diante da Lua:

- Je veux bien vivre; mais vraiment,

L'Idéal est trop élastique!

- C'est l'Idéal, son nom l'implique,

Hors son non-sens, le verbe ment.

- Mais, tout est conteste; les livres

S'accouchent, s'entretuent sans loi! 
- Certes! l'Absolu perd ses droits,

Là ou le Vrai consiste à vivre.

- Et, si j'amène pavillon

Et repasse au Néant ma charge?

- L'Infini qui souffle du large,

Dit: "pas de bêtises, voyons!"

- Ces chantiers du Possible ululent

À l'Inconcevable, pourtant!

- Un degré, comme II en est tant

Entre l'aube et le crépuscule.

- Être actuel, est-ce, du moins,

Être adéquat à Quelque Chose?

- Conséquemment, comme la rose

Est nécessaire à ses besoins.

- Façon de dire peu commune

Que Tout est cercles vicieux?

- Vicieux, mais Tout!

- J'aime mieux

- Donc m'en aller selon la Lune. ${ }^{10}$

O poema acima é constituído por doze dísticos, organizados em perguntas e respostas, onde eu lírico constrói sua reflexão em torno de uma questão fundamental: por que viver? Para Laforgue esse é um dos temas essenciais de sua poesia, e seus poemas são o único lugar onde a transitoriedade da vida pode ser vista como solução, onde não há limite entre o real e o sonho. Veremos no capítulo seguinte que a poesia de Laforgue estará

\footnotetext{
${ }^{10}$ Tradução nossa: "- Desejo muito viver; mas, de fato,/ o Ideal é tão elástico!/ - O Ideal, seu nome o implica,/Fora seu nonsense, a palavra mente/ - Mas tudo é contestável; os livros/ Dormem entre si, matam-se sem lei!/ - Certamente! O Absoluto perde seus direitos,/ Aqui, onde a Verdade consiste em viver./ - E, se eu puder me render/ Repassar ao Nada meu pesar?/ - O Infinito que sopra do largo,/ Diz: "nada de besteiras, vejamos!"/ - Estes campos do Possível ululam/ Ao Inconcebível, portanto!/ - Um degrau, apenas um/ Entre a madrugada e o crepúsculo./ - Ser atual é, ao menos/ Ser adequado a Qualquer Coisa?/ - É assim como a rosa/ Necessária a si mesma./ - Que maneira incomum de dizer/ Que o Todo é um círculo vicioso?/ - Vicioso, mas Todo!/ - O que eu prefiro mesmo é/ partir seguindo a Lua."
} 
sempre em busca de algo inatingível, algo essencialmente original, fazendo-o garimpar, ao contrário de Bandeira, no que há de mais raro e difícil.

$\mathrm{Na}$ mesma posição de observador na qual vimos o sujeito bandeiriano anteriormente, o "je" laforgueano entremeará perguntas e respostas em um diálogo sem interlocução, onde as vozes são reflexo de um sujeito fragmentado em meio à solidão e à melancolia. A presença de substantivos iniciados em letra maiúscula intensificam as imposições da vida sobre o "je", colocando-o entre o limiar do viver e do morrer: " - Un degré, comme II en est tant/ Entre l'aube et le crépuscule." [- Um degrau, apenas um/ Entre a madrugada e o crepúsculo]. Este recurso das maiúsculas é algo muito comum na poesia de Laforgue e denota sua intenção de elevar as coisas comuns ao "plano cósmico" da poesia: "Idéal", "Absolu”, "Vrai", "Tout”, "Quelque Chose”.

Essa linguagem codificada pelo "je" é o eco de uma voz interior angustiada, à procura por algo que possa libertá-lo das amarras entre vida e morte. Nessa eterna busca, o "je" laforgueano não supera sua dor, mas consegue sobreviver a ela. Para garantir sua sobrevivência - e pagando um preço por ela - o "je" será agente de um recurso constante: a derrisão. Para Laforgue, a capacidade derrisiva é um meio de se distanciar das limitações da vida. Mas, no seu caso e, diferentemente de Bandeira, não há salvação.

Para Bandeira, Laforgue fora um poeta de humour e fantasia sarcástica (BANDEIRA apud MORAES, 2001, p. 353) cujo "malheur d'être poète" foi compartilhado em muitos de seus versos. ${ }^{11}$ Por isso, Laforgue leva às últimas consequências uma de suas mais célebres afirmações: "ser original a qualquer preço". E, também, para suportar sua própria sobrevivência também é preciso, acima de tudo, ser irônico a qualquer preço, como se nota já nos primeiros versos de "Dialogue": - Je veux bien vivre; mais vraiment,/ l'Idéal est trop élastique!" [- Desejo muito viver; mas, de fato,/ o Ideal é tão elástico!]. Neste caso, a ruptura se dá no uso da palavra "élastique" [elástico], designando o Ideal como algo inalcançável, fugidio, mas de maneira surpreendente.

Em "Dialogue", o infortúnio do destino é evidenciado nos seguintes versos: "Et, si j'amène pavillon/ Et repasse au Néant ma charge?" [- E, se eu

\footnotetext{
${ }^{11}$ Definição dada por Manuel Bandeira em Noções de história das literaturas. Rio de Janeiro: Editora Fundo de Cultura, 1960, vol. 1.
} 
puder fugir/ Repassar ao Nada meu pesar?]. Essa fuga representa o desejo de morte, questionado por uma das vozes do sujeito. Tal característica consiste na representação de um "je" desamparado, imerso em um mundo onde não vale a pena lamentar e, consequentemente, um "je" pequeno demais para esse lamento.

Mostraremos adiante que, em Laforgue, não há uma preparação para a morte, mas apenas o desejo desesperado da libertação. Não há uma disponibilidade de encontrar, em meio a esta melancolia, algo positivo: “- Être actuel, est-ce, du moins/ Être adéquat à Quelque Chose?// - Conséquemment, comme la rose/ Est nécessaire à ses besoins." [- Ser atual é, ao menos/ Ser adequado a Qualquer Coisa?// - É assim como a rosa/ Necessária a si mesma]. A ironia representa aqui certo ressentimento com a dor e com o fato de "je" ainda estar preso aos "chantiers du Possible" [campos do Possível]. É, então, através desse rancor que, ao contrário de Bandeira, a tendência da poética de Laforgue pode ser considerada negativa.

Em seu diálogo autoquestionador e, portanto, inútil, o "je" fragmentado descobre que não há como fugir do "Tout vicieux" [Todo viciante]. É nesse instante que, ao olhar para o céu e descobrir a presença do astro, seu desejo íntimo se revela: morrer ("m’en aller selon la Lune" [ir embora com a Lua]) é, de fato, a única saída.

Retomando os poemas de Manuel Bandeira, vejamos como o processo de preparação para a morte se dá ainda em A cinza das horas:

Chora de manso e no íntimo... Procura

Curtir sem queixa o mal que te crucia:

O mundo é sem piedade e até riria

De tua inconsolável amargura.

Só a dor enobrece e é grande e é pura.

Aprende a amá-la que a amarás um dia.

Então ela será tua alegria,

E será, ela só, tua ventura... 
A vida é vã como a sombra que passa...

Sofre sereno e de alma sobranceira,

Sem um grito sequer, tua desgraça.

Encerra em ti tua tristeza inteira,

E pede humildemente a Deus que a faça

Tua doce e constante companheira... ${ }^{12}$

Além da extrema preocupação com a forma, visível pela construção de um soneto com rimas opostas ABBA, em "Renúncia", percebe-se que a tentativa de aprendizado com a dor e com a solidão está apenas no início. $O$ "eu" se identifica com a condição de vida que se seguirá conforme a sua condição: "Chora de manso e no íntimo...". O prolongamento desse verso se dá com as reticências, num efeito de introspecção profunda de um "eu" em absoluta solidão, afastado do mundo: "O mundo é sem piedade e até riria". Nesse movimento entre a dor e o seu reconhecimento, o "eu" ultrapassa a angústia da morte a partir do espaço do poema.

Além disso, na primeira estrofe, notamos o exercício doloroso que o "eu" se propõe a fazer, a partir dos verbos "chorar" e "procurar", ambos no imperativo, onde a sensação de dor é intensificada pela pausa do enjambement logo no final primeiro verso. Mas, de certa forma, essa mesma alternativa já demonstra a afirmação da vida que, apesar das amarguras, "procura curtir sem queixa" todo o mal que a crucia.

$\mathrm{Na}$ segunda estrofe, a passagem pela experiência da dor é algo que enobrece o sujeito lírico por sua grandeza e pureza. Em seu universo solitário, a relação entre ele e a dor é vista como forma de aprendizado, construída aos poucos através do exercício do afeto: "Aprende a amá-la que a amarás um dia." O "eu" se mostra, melancolicamente, aberto ao apego com a dor. Embora seja a tristeza, essa lição diária de convívio com a dor the trará algum fruto: "Então ela será tua alegria,/ E será, ela só, tua ventura...". Nesse grupo de

\footnotetext{
12 “Renúncia” (1906), in A cinza das horas, 1917.
} 
versos, há um contraste em relação a forma como o "eu" fala da dor por meio de um vocabulário positivo: "enobrece", "grande", "pura", "alegria", "ventura".

Renunciando à felicidade, o "eu" entrega-se à tristeza como única forma de salvação: "A vida é vã como a sombra que passa.../ Sofre sereno e de alma sobranceira". Aqui há um elogio vigoroso à atitude elevada e humilde, de quem sofre sem exibir a dor, "sobranceiro", resistente, sem se vergar aos obstáculos. Estoicismo talvez.

Quando Bandeira reconhece em cada palavra a poesia, antes mesmo de pensá-la com ideias e sentimentos, é como se toda escolha articulasse 0 poder transformador da composição dos versos, como forma de "chave" para um espaço e tempo diferentes à realidade imposta. É neste ponto em que podemos relacionar a atividade da escrita às ferramentas essenciais para a transposição dos obstáculos, ou melhor dizendo, para sua superação. É possível dizer que, em linhas gerais, toda a obra de Bandeira é permeada pela ideia de superação, ao lado de resignação e sabedoria.

A prática dos versos trará para Bandeira - e também para Laforgue -, como veremos mais adiante, a possibilidade de viver no espaço solitário da obra e, como consequência disso, realizar fora desse mesmo espaço, sua vida inteira. Contudo, ao contrário de Laforgue, quando o "eu" bandeiriano transforma a tristeza em companhia: "Tua doce e constante companheira", é como se a melancolia então se dissipasse, e o que era dor, solidão, transforma-se em algo "acompanhado", mesmo que pela tristeza. Há uma companhia, sempre; há uma alegria, mesmo que em meio à tristeza.

Esse exercício de preparação para a morte ou ainda, de preparação para a dor da vida é algo que se dá num momento em que Bandeira se retira da vida. $\mathrm{E}$ isso acontece principalmente em $A$ cinza das horas. Em seus primeiros poemas, o trabalho com as palavras, a atitude poética como um todo, possibilita uma relação antecipada com a morte, uma relação com o outro tempo, aquele sugerido por Blanchot, onde o eu se coloca fora do mundo, mas convertido para a solidão essencial à construção de um universo próprio das palavras, permitindo que o poeta extraia da experiência do poema, uma alteração do modo de conceber o real: 
Os versos são experiências, ligadas a uma abordagem viva, a um movimento que se concretiza na seriedade e no trabalho da vida. Para escrever um único verso, é necessário ter esgotado a vida. Depois, a outra resposta: para escrever um só verso, é preciso ter esgotado a arte, ter esgotado a vida na busca da arte. (BLANCHOT, 1987, p. 85)

Nesse limiar delicado entre morte e superação (vida), a prática da escrita transforma o peso real das palavras em ferramentas poderosas para a experiência poética. No poema acima, mesmo que para Bandeira, ainda muito jovem, a escrita não fosse objeto factível de reflexão sobre a possibilidade de morrer - apenas um modo de "passar o tempo" -, podemos notar como a escolha e a organização dessas palavras atuavam de maneira poderosa em seu processo de amadurecimento, como uma forma de reconhecimento e de reflexão mais profunda dos fatos.

Ainda em Blanchot, esse confronto com as palavras que precisam ser expostas é a "passagem libertadora do eu ao ele", da auto-observação, o que permite ao poeta o distanciamento necessário para poder dizer, de certa forma, o que não é fácil dizer, como uma forma de recomeço, de ressignificação do mundo: "Escrever para não morrer, confiar-se à sobrevivência das obras, aí está o que ligaria o artista à sua tarefa." (BLANCHOT, 1987, pp. 90-91)

Essa ressignificação em "Renúncia" não nos é apresentada no significado totalizante dos versos, mas sim na forma do poema: o convívio com a dor o faz capaz de observar tal ideia como um princípio disjuntivo, como recusa da permanência do mesmo. Assim, notamos que o momento de reconciliação dá acesso ao poeta a um tempo de latência, de renovação das ideias, um momento de secreta interrogação sobre a possibilidade perturbadora da transformação do mundo em reflexão.

Nessa tensão entre tristeza e alegria, Bandeira reconstrói em um único poema a sua cosmologia tensionada por duas visões elementares: na busca do reconhecimento do mundo, tal como ele é - pleno de angústia sem piedade -, ou então na busca pela transformação desse mundo em forma de desejo humano, redirecionando sua trajetória em forma de versos. Além disso, há no poema um convite para que o eu lírico seja a própria dor: ao adentrá-la para 
com ela conviver, o eu lírico passa a conhecê-la intimamente e ela se dissipa em algo "suportável".

Diferentemente de Laforgue, tentaremos mostrar que a ironia de Manuel Bandeira nem sempre estará ligada ao aspecto cômico ou sarcástico que irá se desenvolver mais tarde. A ironia será mais presente no caráter da ruptura, no questionamento enderaçado ao leitor pela utilização dos contrastes, das possibilidades inusitadas, assim como o pedido humilde de renúncia: "Encerra em ti tua tristeza inteira./ $E$ pede humildemente a Deus que a faça/ Tua doce e constante companheira...". Uma reviravolta proposta pelo poeta que cultiva, desde o princípio, uma resignação destituída de qualquer tipo de derrota. Afinal, que seja doce.

\subsubsection{O canto do poeta "menor" e irônico}

Nas análises acima, tentamos buscar de que maneira a sedimentação do sujeito lírico bandeiriano se deu em suas primeiras experiências poéticas, colocando em evidência a sua relação entre a dor e a iminência da morte com o despojamento e atenuação da linguagem. Em $A$ cinza das horas, o poeta, retirado da vida, atua como sujeito obervador do mundo. Há uma bela imagem construída por Mário de Andrade a respeito de Bandeira:

É por natureza um observador. Se por acaso a doença não aparecesse seria um observador dentro da vida. Se contaria e explicaria os outros e as coisas com essa percepção centrífuga dos psicólogos que tudo observam em função da realidade exterior. [...]

O Manuel da Cinza das horas ouve a conversa das visitas. As poesias relembram geralmente como ideia ou realização outros sujeitos. Fulano disse que. Sicrano fez isso. [...] (ANDRADE, 1987 [1924], pp. 73-75)

Contudo, Bandeira nem sempre esteve na janela, olhando para o mundo de fora de seu apartamento situado na rua do Curvelo. Em muitas ocasiões, o poeta volta-se para o mundo interior, restrito a seu quarto e sala, com o qual compartilhava seus momentos de profunda solidão. Esse universo é também reflexo do seu prórpio interior que transborda facilmente a cada 
palavra desentranhada. Para falar um pouco desse modo de observação interna, vamos saltar para o seu terceiro livro: $O$ ritmo dissoluto.

Neste livro se inicia mais claramente uma nova fase para a produção poética de Bandeira. É quando o poeta, ainda insatisfeito com as tentativas anteriores, começa a se sentir mais a vontade para lançar mão da métrica e experimentar o verso livre na busca por uma liberdade comportamental. 0 próprio Bandeira afirma que em $O$ ritmo dissoluto passara a ousar novas possibilidades rítmicas de que vinha tomando conhecimento nos últimos anos graças à leitura, sobretudo de alguns poetas franceses, entre eles, Jules Laforgue.

Ainda em seu Itinerário de Pasárgada, o poeta maduro entrega-se à reflexão crítica sobre o seu ofício àquela época, ensaiando a compreensão de fatos e relatando sua experiência poética em $O$ ritmo dissoluto:

Tomei consciência das minhas limitações. Instruído pelos fracassos, aprendi, ao cabo de tantos anos, que jamais poderia construir um poema à maneira de Valéry [...]. Na minha experiência pessoal fui verificando que o meu esforço consciente só resultava em insatisfação, ao passo que o que me saía do subconsciente, numa espécie de transe ou alumbramento, tinha ao menos a virtude de me deixar aliviado de minhas angústias. (BANDEIRA, 1984 [1954], p. 30).

Ao constatar que seu modo de conceber poesia era diferente de Valéry, onde em "Mémoires d'un poème" (Variété V) o poeta francês afirma que a primeira condição imposta por ele mesmo no trabalho de criação poética era le plus de conscience possible, ${ }^{13}$ Bandeira admite que se sentia mais reconfortado com a escrita que tinha origem em seu subconsciente ou então aquela provinda de uma espécie de alumbramento. No entanto, ao longo de Itinerário, Bandeira afirma ter compreendido também, "ainda antes de conhecer

\footnotetext{
${ }^{13}$ Bandeira cita ainda, sobre Valéry, "todo o seu desejo era 'essayer de retrouver avec volonté de conscience quelques résultats analogues aux résultats intéressants ou utilisables que nous livre (entre cent mille coups quelconques) le hasard mental'", in Itinerário de Pasárgada. Rio de Janeiro: Editora Nova Fronteira, 1984.
} 
a lição de Mallarmé, ${ }^{14}$ que em literatura a poesia está nas palavras, se faz com palavras e não com ideias e sentimentos" (BANDEIRA, 1984 [1954], pp. 30-31).

Dessas duas formas de compreensão do ofício da poesia, percebemos que o poeta pernambucano transita entre o alumbramento e o esforço consciente, ao retirar cuidadosamente as palavras de seu significado usual para a rede encantatória do poema, entremeando delicadeza e resistência em sua poesia. Abaixo, uma constatação de Bandeira sobre o processo vivido na produção deste livro:

A mim me parece bastante evidente que $O$ ritmo dissoluto é um livro de transição entre dois momentos da minha poesia. Transição para quê? Para a afinação poética dentro da qual cheguei, tanto no verso-livre como nos versos metrificados e rimados, isso do ponto de vista da forma; e na expressão das minhas ideias e dos meus sentimentos do ponto de vista do fundo, à completa liberdade de movimentos, liberdade que cheguei a abusar no livro seguinte, a que por isso mesmo chamei Libertinagem (BANDEIRA, 1984 [1954], p. 75)

Por tratar-se de uma fase de "transição", os poemas passam a ser cada vez mais intercomunicáveis, onde a variação entre tradição e vanguarda já não revela grandes discrepâncias em relação à forma e aos temas. É nesse livro mais especificamente que Bandeira consolidará uma obra que apresenta, em meio a traços aparentemente contraditórios, uma "unidade íntima que não exclui variedade e espontaneidade lírica, que inclui consciência artística e rigor". (HOLANDA, 1980 [1958], p. 146).

Voltado para o interior de seu apartamento, em "Gesso", Bandeira recolhe os fragmentos de sua intimidade para constituir o novo, um objeto restaurado pelas próprias mãos. Vejamos como Bandeira exerce uma de suas primeiras experiências com o verso livre e o que isso implicará em sua maneira de conceber a poesia:

${ }^{14}$ Creio ser interessante citar aqui uma frase de Mallarmé que caracteriza ainda mais esta 'etapa' do fazer poético de Bandeira: "filosoficamente, o verso recompensa o defeito das línguas", in CEuvres complètes, Paris: Gallimard, La Pléiade, 1979, p. 324. 
Esta minha estatuazinha de gesso, quando nova

- O gesso muito branco, as linhas muito puras -

Mal sugeria imagem de vida

(Embora a figura chorasse).

Há muitos anos tenho-a comigo. O tempo envelheceu-a, carcomeu-a,

[machucou-a de pátina amarelo-suja.

Os meus olhos, de tanto a olharem

Impregnaram-na da minha humanidade irônica de tísico.

Um dia mão estúpida

Inadvertidamente a derrubou e partiu.

Então ajoelhei com raiva, recolhi aqueles tristes fragmentos, recompus a [figurinha que chorava.

E o tempo sobre as feridas escureceu ainda mais o sujo mordente da [pátina...

Hoje este gessozinho comercial

É tocante e vive, e me fez agora refletir

Que só é verdadeiramente vivo o que já sofreu. ${ }^{15}$

Este poema é um dos muitos onde podemos identificar uma poética implícita, revelando uma das questões principais do modo de conceber poesia para Manuel Bandeira: o procedimento de desentranhar a poesia "como quem tira o metal nobre das entranhas da terra, como uma garimpagem do que é raro e difícil de conseguir" (ARRIGUCCI, 2009, p. 16). Em "Gesso", tal procedimento de desentranhar equivale também a uma forma de mimese: 0 ato do poeta equivale a uma percepção penetrante do outro, neste caso, da estatuazinha de gesso, e a um "habitar as coisas" que é de fato, o desvelamento de sua natureza mais profunda.

15 "Gesso", in O ritmo dissoluto, 1924. 
Deste modo, a estátua pode representar aqui um segundo "eu" distanciado do eu lírico, porém representante de seu modo de ser mais íntimo. Nos primeiros versos, essa representatividade já se faz evidente: "Esta estatuazinha de gesso, quando nova/ - O gesso muito branco, as linhas muito puras - / Mal sugeria imagem de vida/ (Embora a figura chorasse)."

Narrando os acontecimentos, o "eu" faz a apresentação da estátua que se impõe, inicialmente, como protagonista da história. Em relação à forma, os dois versos mais longos do poema (o de número seis e doze) expressam um processo cumulativo, reforçando a temática da ação do tempo.

Mesmo que na primeira estrofe o terceiro verso aponte para a existência de um simples objeto sem vida, a descrição da estátua remete à juventude, momento em que tal figura não havia sofrido as marcas do tempo. $O$ choro é a primeira marca visível no quarto verso que, iniciado pela conjunção concessiva "embora", define o tom do poema, marcado pela tristeza e melancolia que acompanham o eu lírico desde muito cedo.

O tempo é colocado em seguida, em primeiro plano. "Há muitos anos tenho-a comigo". Esse verso traz o grau de aproximação entre o eu lírico e o objeto, porém ainda com certo distanciamento. "O tempo envelheceu-a, carcomeu-a, manchou-a [...]". Os três verbos utilizados de forma gradativa intensificam as marcas da passagem do tempo observadas pelo homem.

Entretanto, é na terceira estrofe que a relação entre o observador e a estátua se mostra indissolúvel, trazendo ao objeto a carga de humanidade necessária para que os sentimentos mais íntimos sejam representados por meio de sua imagem: "Os meus olhos, de tanto a olharem,/ Impregnaram-na da minha humanidade irônica de tísico." Aqui, o poeta se utiliza da imagem de uma estátua para compor com ele o motivo central de uma paisagem interior.

Nesse momento, o olhar torna-se ação definitiva para o encadeamento das reflexões seguintes. Em seu grande "Ensaio sobre 'Maçã'”, Davi Arrigucci Jr. cita a forma Ut pictura poiesis (de Horácio) insinuando o paralelismo entre pintura e poesia. É certo que em "Maçã", a natureza-morta traz consigo a carga de mimese entre Homem e Natureza, o que se diferencia de "Gesso", por se tratar de um objeto. Porém, não podemos deixar de notar que nos dois poemas as imagens da maçã e da estátua são construídas de modo análogo a uma 
pintura, quadro que se constrói diante dos olhos do eu lírico e do leitor para a exposição de suas reflexões:

$\mathrm{Na}$ obra de Bandeira se revela uma tendência poderosa para a composição na forma da natureza-morta: seres e coisas, atos e sentimentos retirados de seu contexto habitual, passam a figurar num contexto diverso, ao mesmo tempo que depurados de toda ganga bruta e imantados por nova e forte carga expressiva." (ARRIGUCCI, 2009, p. 36)

Assim, ao trazer para o primeiro plano um objeto antes descontextualizado, o poeta estabelece a junção entre a 'humanidade' do gesso à sua própria "humanidade irônica de tísico", intimamente relacionada à ação do tempo. Na pátina amarelada, cada mancha é constitutiva de uma natureza humilde que se revela ironicamente melancólica tanto para o sujeito quanto para a estatuazinha.

O objeto antes distanciado, agora se faz evidente, constituído de uma humanidade impregnada em si. Essa 'humanidade' pode ser vista como uma tentativa de organização do caos, mesmo que este seja o caos microcósmico da sala de um apartamento.

O efeito surpresa, aliado à utilização das palavras "irônico" e "tísico", evidencia uma nova possibilidade e um amadurecimento diante das limitações impostas pelo tempo que passou e as marcas com as quais o "eu" bandeiriano aprendeu a conviver, lapidado pela ternura, porém transformado pela ironia. $A$ humanidade irônica à qual ele se refere é um dos aspectos fundamentais para a transformação daquele eu desacreditado em outro: o da experiência e da sabedoria, que enxerga na vida e nas suas limitações a possibilidade do sonho.

Porém, a partir da estrofe seguinte, quando "a mão estúpida" derruba a estátua, retoma-se a ideia de que, para Bandeira, a capacidade de sonhar, de superar as dificuldades é sempre conquistada após o sofrimento, com uma forte carga de dor. É no chão, ajoelhado para recuperar os cacos que o poeta consegue extrair das palavras a carga lírica necessária: "Então ajoelhei com raiva, recolhi aqueles tristes fragmentos, recompus a figurinha que chorava."

Neste segundo momento do poema, quando há a ruptura, um processo simultâneo se instala: a estátua irá reverter a destruição em construção. E, de 
maneira surpreendente, o sujeito lírico revelará a sua identidade de poeta. Para Murilo Marcondes de Moura, este processo está relacionado à própria criação poética:

Não por acaso, o sujeito agora é o poeta, que contrapõe à destruição temporal uma construção artificial, próxima à operação poética. Os verbos "recolher" e "recompor" são muito significativos e devem ser associados à ideia de "desentranhar" poesia da realidade mais cotidiana. (MOURA, 2001, p. 38)

A analogia da operação restauradora com o processo poético de Bandeira é evidente, assim como o "recolhimento atualizante da matéria dispersa - matéria que sensibiliza o poeta e é por ele sensibilizada, fundindose ambos numa troca de mútua revelação." (VILLAÇA, 1987, p. 31)

Mas, por outro lado, Murilo Marcondes de Moura afirma:

a expressão "ajoelhei com raiva" é quase um oxímoro, ao indicar, simultaneamente, humilhação e atuação forte. A construção paradoxal tem aqui enorme precisão, pois abrange tanto a situação do eu submetido à devastação do tempo, como também sua capacidade de recompor as perdas numa integridade que lhe é própria. (MOURA, 2001, p. 38)

O caráter exclusivo desta integridade bandeiriana se faz, portanto, por meio da afirmação da vida que se revela, em muitos momentos, sobrepujante à negatividade. Ao atravessar o alvoroço da inquietação poética, o sujeito lírico parece ter encontrado repouso nestes versos. "Catarse discreta em que, se fica ainda uma certa amargura, não permanece o ressentimento." (VILLAÇA, 1987, p. 32). Os dois últimos versos trazem a revelação de algo que estava oculto no objeto envelhecido, propondo, assim, uma reconstrução: "Hoje este gessozinho comercial/ É tocante e vive, e me fez agora refletir/ Que só é verdadeiramente vivo o que já sofreu." A ação de olhar a estátua traz finalmente ao poeta a consciência de tudo o que lhe custou a passagem dos anos. O gessozinho comercial recomposto é a prova da reorganização do caos, da resistência do "eu" que reintegra suas perdas numa espécie de reviravolta irônica - a superação será sempre uma grande surpresa. 


\subsection{A escolha pelo desabafo “Que je suis piètre et sans génie!”: Jules}

\section{Laforgue}

Considerado um mestre por T.S. Eliot, Ezra Pound, Marcel Duchamp, entre outros, Laforgue implicou uma mudança radical no modo de conceber a literatura para alguns poetas brasileiros, como no caso de Bandeira. Sobre a importância da poesia de Laforgue, o poeta Mário Faustino afirmou, em meados dos anos 1960:

Antes de qualquer coisa, Laforgue fez o que podemos chamar de serviço de limpeza, de higiene, de purgação, de crítica. Depois dele um Flaubert não teria mais coragem de escrever Salammbô [...], ninguém na França ousará mais escrever pieguices autoacalantos etc. Ah, se Laforgue (e Corbière) fosse mais lido no Brasil! (FAUSTINO, 2004, p. 65)

Talvez Mário Faustino se referisse ao modo de conceber a poesia que fez de Laforgue não apenas um poeta de ironia sofisticada, mas alguém que rompeu com as limitações do gênero confessional. Na época em que se propôs a escrever e organizar Les Complaintes, o gênero dos lamentos, visto como algo enraizado na cultura popular e fora do cânone literário da época era algo extremamente arriscado a fazer, sobretudo para sua primeira coletânea de versos a ser publicada. Seu desenvolvimento poético que ocorre entre os anos de 1880 e 1887 denota a emergência da construção de uma figura do autor, a qual se edificará, nesta primeira fase, em práticas de escrita específicas e, ao mesmo tempo variadas, como ensaios filosóficos e publicações em revistas. Sem falarmos de sua primeira coletânea de versos, Le Sanglot de la Terre (1881), que Laforgue desistiu de publicar e entregar os manuscritos ao seu editor. Estas tentativas manifestam o percurso de um poeta que estava em busca de uma poética própria e em busca de si mesmo.

É curioso observar em que medida a elaboração da sua obra é fruto de bruscas rupturas, acompanhadas de um desenvolvimento inesperado. Além da produção poética, Laforgue colaborou com diversas revistas literárias da época, como La Vogue, La Cravache, Lutéce e Revue Indépendante, onde alguns de seus "contos-paródia", que mais tarde formariam o livro Moralités 
Légendaires (1887), foram publicados pela primeira vez. Essa justaposição de variações qualitativas ao longo de sua produção nos faz pensar que sua escrita sempre foi um work in progress, uma busca pelo recomeço e pelo inacabamento perpétuo - experiência livre de qualquer exigência de unificação ou homogeneização de uma obra.

De acordo com Henri Scepi,

ao afirmar a primazia de uma constante evolução, determinante para todos os níveis das atividades humanas e naturais, Laforgue autoriza-se a fazer uma revisão total dos cânones estéticos e dos seus valores presumidamente atemporais. (SCEPI, 2000, p. 14).

Em 1880, Laforgue iniciou suas pesquisas a respeito da Philosophie de l'Inconscient, de Hartmann, as quais se tornaram indissociáveis de sua aspiração por uma poética em progresso. É possível dizer que o poeta passa a se interessar inexoravelmente pela lição hartmaniana a partir do momento em que descobre que "o Inconsciente, através de seu princípio de evolução, é fundado a não preconizar nenhum outro objetivo a não ser o novo, o novo e indefinidamente o novo" (LAFORGUE, 1995 [1903], p. 213).

Laforgue buscou, a cada tentativa de obra, um estado primitivo da palavra, a palavra enfim liberada de regras retóricas e normas acadêmicas. $O$ conceito do "original" que estará, a partir de 1882, no centro de suas preocupações, dá provas disso: o poeta desejava um ideal estético que provocasse uma visão de mundo profundamente renovada. Tal ideal está relacionado ao abandono da versificação tradicional, que a partir da produção dos primeiros poemas de Les Complaintes, em 1882, passa a ser a única forma de escrita possível para Laforgue:

J'oublie de rimer, j'oublie le nombre des syllabes, j'oublie la distribution des strophes, mes lignes commencent à la marge comme la prose. L'ancienne strophe regulière ne reparaît que lorsqu'elle peut être un quatrain 
populaires etc. [...] Je ne ferai jamais plus de vers qu'ainsi. ${ }^{16}$ (LAFORGUE, 1995 [1886], p. 864)

Laforgue foi um dos primeiros poetas a experimentar verdadeiramente o verso livre e além desse fato, muitas de suas propostas estéticas o colocam numa posição de precursor: seja por sua investigação a respeito do Inconsciente e da filosofia de Schopenhauer, seja pela utilização de associações verbais ao acaso que hoje nos é familiar e tão recorrente entre os surrealistas.

Mas, antes de romper com os padrões estéticos tradicionais, em seus primeiros versos, reunidos postumamente em Premiers poèmes (publicado apenas em 1903), Laforgue teria a preocupação formal anterior à sua busca pelo novo. Além disso, nota-se ainda uma concepção pessimista do mundo que transparece sobre a repercussão de sua sensibilidade diante do leitor. "O medo de estar só, a angústia de ser solitário o atormenta", afirma François Ruchon (1924, p. 62) sobre o assunto. Vejamos nos dois exemplos abaixo algumas características dessa primeira etapa da produção de Laforgue:

\author{
$[\ldots]$ \\ Ô toi ! qui que tu sois, Frère, Unique Science, \\ squelette ou cerveau fou qu'aura choisi le sort \\ Pour être le Dernier, seul, dans le grand silence, \\ Pour voir que c'était vrai, qu'il n'est plus d'espérance, \\ Rien n'ouvrant les cieux, tout continuant encor, \\ La terre pour jamais va sombrer dans la mort ${ }^{17}$
}

\footnotetext{
16 "Esqueço de rimar, esqueço o número das sílabas, esqueço a distribuição das estrofes, minhas linhas começam na margem como a da prosa. A antiga estrofe regular reaparece apenas quando faço um quarteto popular etc. [...]. Nunca mais farei versos que não sejam assim."

17 Tradução nossa: "Ó tu! Quem quer que seja, Irmão, Única Ciência,/ esqueleto ou cérebro louco que terá escolhido o destino/ para ser o Último, sozinho, no grande silêncio,/ Para ver que tudo era verdade, que não há mais esperança,/ Nada abrindo os céus, tudo permanecendo ainda,/ A terra para sempre desaparecerá na morte". Trecho do poema "L'Éspérance", in CEuvres Complètes, 1995, [1903].
} 
$[\ldots]$

Mais non ! je ne sais rien. - Je suis la Douleur même

Je souffre d'aimer trop ; je sais que c'est mon sort,

Mais j'en veux épuiser la douceur ; j'aime, j'aime,

Je veux saigner pour tout, saigner, toujours, encor...,

Pour être épargné de la mort. ${ }^{18}$

$[\ldots]$

Nas duas estrofes selecionadas é visível como o medo da solidão e da morte absorve o "je" que está diante do vazio, da não-esperança que o oprime enquanto espera pelo fim. Essa opressão pode ser encontrada, por exemplo, nos substantivos utilizados em letras maiúsculas, como "forças maiores que se confundem com o 'je' abandonado, exilado no mundo" (SCEPI, 2007, p. 65). Podemos afirmar que, nessa primeira fase, o poeta apropria-se de certos substantivos como se esses fizessem parte de um vocabulário próprio, ou ainda, de uma coletânea de palavras que fundam uma espécie de dicionário meta-simbólico. Esse recurso de escolha e trabalho com os absolutos será utilizado por Laforgue até seus Derniers vers.

Na estrofe do poema "Désolation", a construção de imagens dá indícios do desespero e do desejo de morte, aqui relacionados a um amor não correspondido: "Je souffre d'aimer trop". Ainda antes, podemos ver que o emprego da letra maiúscula na palavra "Douleur" [Dor], além de ser objeto da opressão sofrida pelas interferências do mundo, é marca de um apagamento do "je" que já não a suporta mais, e que finalmente se perderá nessas representações. Assim como vimos em "Renúncia", aqui o "je" também se transforma na dor, dissipa-se e, por isso, desaparece.

Nesse apagamento, o "je" se confunde e se revela como "Douleur même", como signo daquilo que é o seu desejo e solução para o fim: "Je veux saigner pour tout" pois, quando chegar a morte, ele já terá sofrido bastante e sua passagem será indolor. Nesse sentido, O verbo "épargner" [poupar,

\footnotetext{
${ }^{18}$ Tradução nossa: "Mas não! eu não sei nada. - Sou a própria Dor/ Eu sofro por amar tanto; sei que é meu destino/ Quero assim esgotar a doçura; eu amo, eu amo/ Eu quero sangrar por tudo, sangrar, sempre, ainda,/ Para ser poupado da morte." Trecho extraído do poema "Désolation", in CEuvres Complètes, 1995 [1903].
} 
economizar] é indicativo dessa solução, que não livra o "je" da dor, mas piedosamente torna-se verbo de ação do sujeito "morte".

Aqui, seria precipitado, por ser um tom muito diverso, falarmos de "Consoada", poema de Bandeira que revela uma tentativa análoga de organização para a espera da morte, com resolução muito contrastante. Mais adequado seria relembrar aqui de "Desesperança", poema do primeiro livro de Bandeira, A cinza das horas, em que a dor também transforma o "eu" em exilado, "repelido e estrangeiro no mundo". Cabe lembra que, em Laforgue, no que diz respeito ao "je", essa organização se dá de maneira trágica, através do ato de sangrar.

\section{$[\ldots]$}

Minha respiração se faz como um gemido.

Já não entendo a vida, e se mais a aprofundo,

Mais a descompreendo e não the acho sentido.

Por onde alongue o meu olhar de moribundo,

Tudo a meus olhos toma um doloroso aspecto:

E erro assim repelido e estrangeiro no mundo.

Vejo nele a feição fria de um desafeto.

Temo a monotonia e apreendo a mudança.

Sinto que minha vida é sem fim, sem objeto...

- Ah, como dói viver quando falta a esperança! $!^{19}$

Ora, como podemos observar, no poema uma mesma opressão causada pela vida é também sentida pelo "eu" bandeiriano, que não encontra mais seu lugar ao mundo. Ele "descompreende", pois não há esperança. A dor está posicionada no mesmo lugar de esmagamento do "eu", onde ali se confundem e se revelam num exercício de busca para a solução final. Mais adiante veremos como esse lugar propício à dor bandeiriana se mostra em alguns de seus primeiros poemas.

\footnotetext{
${ }^{19}$ Trecho de "Desesperança" (1912), in A cinza das horas, 1917.
} 
$\mathrm{Na}$ estrofe retirada de "L'Éspérance", o "je" se coloca em posição de questionamento de sua própria identidade e seu papel no mundo. As imagens construídas estão relacionadas ao universo da morte: "squelette", "grand silence", "seul". Esse imaginário traz o tom de pessimismo do qual Laforgue nutriu sua produção através das leituras assíduas de Spinoza, Schopenhauer e Hartmann, como falamos no capítulo anterior. Para ele, a expressão shopenhauriana da "atrofia do querer", por exemplo, seria uma possível resposta para os males do mundo, ligada diretamente ao seu sentimento de derrota diante da vida. Alguns trechos de suas Mélanges posthumes trazem as seguintes observações:

Pas de remède absolu, universel, qui suprime le mal universel. Jamais on n'atteindra l'essence même de la Volonté, le principe mystérieux, insaisissable qui circule partout. II faut se contenter du suicide matériel et du renoncement. ${ }^{20}$ (LAFORGUE, 1995 [1903], p. 10)

Essa renúncia ou retração do sujeito em relação às determinações do querer e às solicitações frustrantes do real formam a chave para a construção de uma poética conceitual que dará lugar às especulações metafísicas do poeta. Aos poucos, a poética de Laforgue vai tomando forma e sob os artífices de uma super-expressividade, os versos da coletânea abandonada, Le Sanglot de la Terre [O soluço da terra] são consumidos por muitas lágrimas e corações em chamas: o eu lírico se identifica com as figuras que ele próprio metaforiza, pela pureza dos arquétipos, a efusão dos sentimentos e a explosão da angústia.

Dividido originalmente em cinco partes, que funcionam como uma espécie de diário [Lamasabacktani, Angoisses, Poèmes de la mort, Résignations infinies e Spleens], Sanglot foi a tentativa de traçar um percurso filosófico que viria, de maneira introspectiva, ordenar e esclarecer o "caos da existência". Os versos, considerados "vers philos", fortemente influenciados por

${ }^{20}$ Tradução nossa: "Não há remédio absoluto, universal, que suprime o mal universal. Nunca atingiremos a verdadeira essência da Vontade, o princípio misterioso, incessante que circula em todos os lugares. É preciso se contentar com o suicídio material e com a renúncia.", in CEuvres Complètes, 1995 [1903]. 
suas leituras de filosofia citadas anteriormente, desenvolvem alguns dos refrãos da obra de Laforgue, a saber, a meditação sobre o vazio e a obsessão pela origem e pelo fim. Vale mencionar que tais versos sofrem, ao mesmo tempo, forte influência baudelairiana.

Esses versos reatualizam algumas categorias apresentadas por Baudelaire, como por exemplo, o pensamento da modernidade sob os valores do "fugidio" e do "ocasional", apresentados em Le Peintre de la vie moderne. A partir desses conceitos, Laforgue defenderá uma estética fundada sob os predicados do fortuito, do inacabado, do vir a ser. Suas fórmulas nos convidam a ver os poemas como uma experiência dupla: por um lado, uma tentativa de colocar em prática sua estética da Vida, por meio do pessimismo e da "atrofia do querer" e, por outro lado e ao mesmo tempo, a procura por um discurso instável, inédito, sempre pronto a desmoronar.

Abaixo, o poema "La première nuit", que abre a terceira parte do livro, intitulada Variations sur la mort, pode nos ajudar a compreender melhor de quais substratos o poeta se utilizou para compor a obra:

Voici venir le soir doux au vieillard lubrique.

Mon chat Mürr, accroupi comme un sphinx héraldique,

Contemple inquiet de sa prunelle fantastique

Monter à l'horizon la lune chlorotique.

C'est l'heure où l'enfant prie, où Paris-Lupanar

Jette sur le pavé de chaque boulevard

Les filles aux seins froids qui sous le gaz blafard

Vaguent flairant de l'œil un mâle de hasard.

Moi, près de mon chat Mürr, je rêve à ma fenêtre.

Je songe aux enfants qui partout viennent de naître, Je songe à tous les morts enterrés d'aujourd'hui.

Et je me figure être au fond du cimetière

Et me mets à la place en entrant dans leur bière 
De ceux qui vont passer là leur première nuit. ${ }^{21}$

Os primeiros versos do soneto "La première nuit" já denotam uma característica ligada à lição baudelairiana, onde as cenas melancólicas e urbanas são presença marcante no pano de fundo das angústias do "je" de Sanglot de la Terre. A morte aqui representada pela noite chega docemente e cai sobre o colo de um velho libidinoso. Esta é a representação que Laforgue utiliza para a cidade, o lugar onde todas as malícias e perversidades são permitidas. Paris não é mais a mesma: a cidade, a cada instante, muda seu comportamento; a melancolia do "je", no entanto, não muda.

Segundo Ross Chambers, em um de seus ensaios sobre o poema "Le Cygne" de Baudelaire, o anonimato das multidões urbanas tornou possível a experiência da projeção. Trouxe a possibilidade da perda de uma referência manifesta, uma alteridade irredutível da modernidade. Essa experiência nas ruas da cidade - as pessoas que passam, os encontros que se fazem e o que se vê, são também peças importantes para a construção dos anseios e angústias do "flâneur" que observa e tenta apreender a fugacidade dos acontecimentos.

'Leitor do texto e da cidade, o 'flâneur' apenas apreende as coisas sob a forma de fragmentos, cortados do contexto que lhes dão sentido" (CHAMBERS, 1987, p. 170). De acordo com Chambers, sua experiência é como a da metonímia, onde o sentimento da totalidade interna não é o único que lhe falta, mas também toda e qualquer possibilidade de totalização com o mundo. É sob esse estado de melancolia que o "je" laforgueano observa de sua janela, no

\footnotetext{
${ }^{21}$ Tradução nossa: "Vejam o cair da noite doce para o velho lúbrico./ Meu gato Mürr, sentado como uma esfinge emblemática,/ Contempla inquieto de sua fantástica pupila/ Subir ao horizonte a lua anêmica.// É a hora onde a criança reza, onde Paris-Bordel/ Lança sobre as calçadas de cada bulevar/ As jovens de seios frios que sob a luz pálida/ Vagam à procura de um homem de sorte.// Perto de meu gato Mürr, sonho a minha janela./ Sonho com as crianças que em todos os lugares acabaram de nascer,/ Sonho com todos os mortos enterrados hoje.// E me imagino estar no fundo do cemitério/ E me coloco no lugar, entrando em seus caixões/ Daqueles que lá vão passar sua primeira noite." Trecho extraído do poema "La première nuit", in Le Sanglot de la Terre, 1881.
} 
interior do lugar que o protege, a noite que cai sobre as mãos perversas da cidade.

É curioso notar que quem o acompanha nessa experiência de observação é um gato chamado Mürr. Esse personagem faz referência ao nome de uma obra inacabada de Hoffmann, ${ }^{22}$ um romance autobiográfico, dividido em dois volumes, escrito por um gato poeta que aprende a escrever. Diante dessa associação, é possível dizer que há aqui um movimento de projeção do "je" sobre o gato que também é sujeito da ação de meditar, em sua posição de esfinge enigmática, a cidade, a noite que cai, a Lua anêmica que sobe aos céus.

Na segunda estrofe, o mesmo momento para a prece das crianças é aquele que abre as portas da "Paris-Lupanar" [Paris-Bordel]. As ruas da cidade e o que elas oferecem constituem um tema de aproximação entre o grotesco e o sublime: como se sabe, as ruas são um lugar para observar a cidade em seu pleno movimento e, dada esta condição dinâmica, surge o sublime como um valor que the seria inexorável; por outro lado, o grotesco nunca deixa de estar ali presente, pois a rua pode ser considerada, concomitantemente, as entranhas da cidade. Ela também dá a ver as mazelas da civilização. Com isso, as ruas implicarão a relação íntima que o "je" acaba possuindo com o seu lugar.

É interessante notar que nesse ambiente lúgubre em que o "je" constata o mundo, sua melancolia pode servir, paradoxalmente, como um meio de transcender os significados de uma vida sem referência, como forma de dispersão para o espírito; mas também será, ao mesmo tempo, o elemento fundamental para a imobilidade do sujeito, o lugar de onde ele não consegue sair. A melancolia, portanto, será o fator responsável pela evasão do sujeito nas estrofes seguintes.

Separando-se daquilo que rejeita, do que foi visto nos versos anteriores, os dois últimos tercetos de "La première nuit" trazem o "je" envolto pela moldura do sonho: "Je rêve à ma fenêtre", "Je songe aux enfants [...]". Ele

\footnotetext{
${ }^{22}$ O nome completo da obra é Lebensansichten des Katers Mürr (1819-1821). Mürr era o nome do verdadeiro gato de Hoffmann. A obra ficou inacabada pois quando seu gato morreu o autor se recusou a continuá-la.
} 
se permite sonhar com todas as crianças que acabaram de nascer e com todos os mortos enterrados naquele dia. A partir dessas imagens, os versos constroem outro paradoxo que diz respeito a uma questão fundamental na obra de Laforgue: nascer $X$ morrer ou ainda, por que não, morrer $X$ nascer.

Tanto para o nascimento quanto para a morte, a dor é inevitável. Tal percepção da amargura pelo "je" intensifica a ideia de que o nascimento também é uma forma de dor: nascer é estar desamparado no mundo, é estar abandonado à vida que acaba de começar. Por outro lado, a morte pode ser entendida como um renascimento: após passar pela vida, e pelo processo de nascer-sofrer, ela seria a solução "indolor", o desfecho necessário, como pudemos perceber em poemas anteriores. Também seria possível associar o título do poema à ideia de renascimento, pois, além do substantivo "nuit" [noite] representar a morte, o adjetivo "Première" dá a ideia de início e, portanto, de recomeço.

Mas, permitir-se sonhar é proteger-se da dor de nascer ou morrer: o devaneio resguarda o "je" em um lugar onde ele possa seguir livremente em busca de seu desejo. Abarcada pelo sonho, a morte seria possível sem que, de fato, um cadáver siga para o cemitério, ou seja, a atividade onírica evita, aqui, que um morto tenha de ser colocado efetivamente no caixão [bière]. Esse outro "je" deslocado passa a ser representante de seu desejo oculto: morrer é se proteger do mundo que se agita lá fora, é retornar a um lugar de origem, encontrar algo que foi perdido.

Em função destas imagens, e sobretudo daquela em que o "je" se vê entrando no caixão, fomos buscar nos estudos dos psicanalistas Nicolas Abraham e Maria Torok possibilidades de interpretação para esses elementos. Psiquicamente, o que estaria em jogo numa vontade como essa? O que levaria um sujeito a encontrar um tipo de "satisfação" ao se enclausurar num caixão?

Para pensarmos na questão, no entanto, devemos antes entender certos pressupostos de Abraham e Torok. Os autores sugerem, de início, que para todo aspecto de realidade que nos é dolorosamente vivido há um movimento de modificação oculta no psiquismo. Oculta porque será preciso mascarar - aqui no nosso caso, através do sonho -, tanto a realização do idílio 
(marcado por uma excitação libidinal, um desejo, em suma, que o psicanalista acredita ser simultâneo ao momento da dor) quanto a da perda.

Podemos, nesse momento, entender mais claramente o que significa 0 mecanismo de identificação. Seria importante relembrarmos da fórmula metapsicológica proposta por Freud, na qual ele apresenta "o ego como disfarçado sob as características do objeto", o que por sua vez leva Abraham e Torok à ideia de que a sombra do objeto pode se projetar no ego, ou seja, é como se aí o objeto usasse o ego como máscara. O ego ou alguma outra fachada. Assim, o sujeito (vivo) se reconhece no corpo (morto) que jaz na cripta: eis a identificação. Mas trata-se, portanto, de uma identificação oculta e imaginária, ou melhor, de uma "criptofantasia", que por sua natureza dolorosa não conseguiria se mostrar às claras.

Ao pensarmos no poema, o fantasma que percorre o cemitério e entra no caixão é o objeto pelo qual o "je" real se mascara. A relação entre o eu lírico de Laforgue e o eu melancólico dos psicanalistas é, com efeito, surpreendente:

De tal conjuntura resulta a instalação no seio do ego de um lugar fechado, de uma verdadeira cripta, comparável a formação de um casulo em torno da crisálida [...]. Ela recai não simplesmente sobre um objeto que não existe mais, mas essencialmente sobre o "luto" que levaria a esse "objeto" [...] (ABRAHAM \& TOROK, 1995, p. 280)

A "sombra do objeto", ou seja, nesse caso, o "je" do sonho, não cessa de divagar em torno da cripta até se reencarnar na própria pessoa do sujeito. Tal mecanismo, que consiste em trocar sua identidade por uma identificação fantasística com a vida de "além-túmulo" do objeto perdido, será denominado por Abraham de "identificação endocríptica". É assim que o sujeito melancólico traduz, pela via da queixa, a sua fantasia: o sofrimento [que o sujeito sente pelo] objeto endocríptico (leia-se, o "je" morto que vai ao cemitério) expressa outro sofrimento, talvez ainda mais verdadeiro, que é o do "je" (vivo) que não sabe como cicatrizar a ferida da perda.

Seria um melancólico um morto-vivo? Precisamos ser cautelosos a esse respeito, pois não podermos afirmar a natureza dessa identificação a partir do modelo clínico psicanalítico. Assim é preferível falar que, a partir 
dessa "poética da cripta", o "je" se sente protegido - mas não por muito tempo - ao menos durante seu sonho, do mundo por trás de sua janela.

Acerca deste mesmo tema, Manuel Bandeira trabalhou brilhantemente em "Poema de finados":

Amanhã que é dia dos mortos

Vai ao cemitério. Vai

E procura entre as sepulturas

A sepultura de meu pai.

Leva três rosas bonitas.

Ajoelha e reza uma oração.

Não pelo pai, mas pelo filho:

O filho tem mais precisão.

O que me resta da vida

É a amargura do que sofri.

Pois nada quero, nada espero.

E em verdade, estou morto ali. $^{23}$

$\mathrm{Na}$ segunda estrofe já percebemos a ambivalência causada pela colocação de uma vírgula no verso "Não pelo pai, mas pelo filho". Essa pausa nos propicia uma leitura dupla: podemos interpretar que o "eu" "tem mais precisão" pelo fato da perda do pai, ou ainda, na verdade é o próprio "eu" que se vê sepultado, perdendo a vida. Já na terceira e última estrofe, percebemos que o sujeito se identifica de fato com o pai morto, sem, entretanto, conseguir

[...] redimensionar seus afetos, desligar-se da imagem paterna e reconstituir-se. Uma parte sua foi depositada no outro e com ele desapareceu; a identificação com o pai tornou impossível ao ego perceberse vivo e diferente do objeto, o que o fez ver-se também como um morto. (ROSENBAUM, 2002, p. 108)

23 "Poema de finados", in Libertinagem, 1930. 
Vejamos também o poema "A Virgem Maria":

O oficial do registro civil, o coletor de impostos, o mordomo da

[Santa Casa e o administrador do cemitério de S. João Batista

Cavaram com enxadas

Com pás

Com as unhas

Com os dentes

Cavaram uma cova mais funda que o meu suspiro de renúncia

Depois me botaram lá dentro

E puseram por cima

As Tábuas da Lei

Mas de lá de dentro do fundo da treva do chão da cova

Eu ouvia a vozinha da Virgem Maria

Dizer que fazia sol lá fora

Dizer in s i s t e n t e m e n t e

Que fazia sol lá fora. ${ }^{24}$

No poema acima, não fica claro para o leitor se se trata de um sonho, ou ainda, de um pesadelo. Mas sabemos que neste poema o "eu" bandeiriano trabalha com as imagens de uma situação que poucos discordariam ser profundamente angustiante: ser enterrado vivo. Os personagens responsáveis por seu enterro são, provavelmente, as pessoas assustadoras relacionadas ao "eu", enumeradas logo no primeiro verso: "O oficial do registro civil, o coletor de impostos, o mordomo da Santa Casa e o administrador do cemitério de S. João Batista"; pessoas ligadas à lei ou aos serviços burocráticos de saúde.

É importante lembrar, ao destacarmos a forma do poema, que ele foi inserido em Libertinagem, livro que determina um movimento interno de constituição do estilo e da estrutura da obra, assim como Laforgue em Le Sanglot de la Terre. Diferentemente do soneto "La première nuit", Bandeira utiliza-se dos versos livres e das repetições para dar forma ao seu instante de desespero.

\footnotetext{
24 "A Virgem Maria”, in Libertinagem, 1930.
} 
As repetições inseridas na primeira estrofe servem para enfatizar 0 movimento de retirada da terra do chão: "Cavaram com enxadas", "Com pás", "Com os dentes", "Cavaram uma cova". As aliterações da letra "c" e a anáfora da palavra "com", prenunciam a cova, o formato e a profundidade do buraco na terra. O ritmo longo do primeiro verso é entrecortado com os versos curtos seguintes, que precipitam a descida do "eu" até a cova: "Depois me botaram lá dentro".

Os elementos narrativos e dramáticos aparentemente dominam a primeira estrofe, escrita em terceira pessoa do plural, sem que percebamos a presença do sujeito lírico. O buraco profundo reprime o "suspiro de renúncia" do "eu" bandeiriano. Sua única arma, a renúncia, não era suficientemente forte para lutar contra a armadilha de seus inimigos. Sem um motivo preciso, o "eu" cumpre implacavelmente seu destino para a morte. O "eu" é, portanto, enterrado sob as "Tábuas da Lei", demonstrando para o leitor a força e peso das práticas sociais contra o sujeito solitário e impotente.

A segunda estrofe, iniciada pelo advérbio "Mas", dá ao leitor a sensação de esperança diante do fim cruelmente imposto nos versos anteriores. A mudança para a primeira pessoa do singular marca a distância e o apagamento do sujeito em relação ao mundo que ficou para fora da cova: é nesse momento de solidão absoluta que a melancolia e o desespero se intensificam para o leitor.

Contudo, a salvação está representada na "vozinha da Virgem Maria". A presença da santa também demonstra a ligação entre religião e morte da qual Bandeira se utilizou em muitos outros momentos de sua obra, como nos poemas "Preparação para a morte", "Canto de natal" e "Ubiquidade". A vozinha da Virgem seria representante do chamado para a vida depois da morte, uma vida plena de luz: "fazia sol lá fora". Nessa possibilidade de saída, mas agora para uma segunda chance, a fatalidade torna-se então catalisadora de seu desejo íntimo de finalizar a vida. Notar, ainda, o diminutivo "vozinha" demarcando as diferentes proporções da luz e das trevas; essas parecem se sobrepor à imagem solar, tão diminuta e no entanto tão consoladora.

De acordo com Yudith Rosenbaum, "[...] o apego do sujeito lírico às experiências findas (ou a traços que a presentificam) se explicaria pela 
necessidade de resgatar a vida na morte, a fim de que a existência do eu possa reconstituir-se" (ROSENBAUM, 2002, p. 104). Tal necessidade faz com que 0 sujeito bandeiriano também se utilize do recurso da "identificação endocríptica".

Isso é visível tanto em "Poema de finados", onde a identificação com o pai morto pode ser considerada recurso semelhante ao da "identificação endocríptica”, em que a dor é causada pelo esvaziamento completo do ego; quanto em "A Virgem Maria", onde tal recurso de identificação faz com que aquele "eu" enterrado em uma cova seja o "eu" protegido do mundo circundante; o chamado da Virgem pode ser visto como a possibilidade de renascimento para uma segunda vida, sem dor.

Retornando ao percurso poético de Jules Laforgue, em 1881, o poeta confessa a Gustave Kahn, a respeito de Le Sanglot de la Terre: "mon volume de philosophiques commence à me dégoûter"25 (LAFORGUE, 1986 [1882], p. 67). Esta etapa de reflexões hesitantes sobre uma nova poética colocam Laforgue diante da dúvida e do afastamento do centro de sua obra, trazendo como consequência o desinteresse progressivo por seu trabalho.

De acordo com Jean Pierre-Bertrand, "é o próprio lirismo que se coloca em questão nos primeiros poemas de Laforgue" (BERTRAND, 1988, p. 77). O espaço oferecido pelo poema para a expressão de uma sinceridade profunda necessitará, a partir daí, ser redefinido pelo poeta, no que diz respeito à forma e ao conteúdo.

É neste momento de sua produção que sua concepção estética se firmará e que sua poesia legitimará a ruptura. Sua reflexão crítica se cristaliza em torno de questões como a imitação, o lirismo filosófico e o profetismo bavard, componentes máximos de sua coletânea abandonada.

De acordo com o crítico literário Daniel Grojnowski, Les Complaintes é o "ponto de partida de um novo modo de conceber poesia, por meio do qual as discordâncias e os hibridismos são livremente permitidos" (GROJNOWSKI, 1997, p.

\footnotetext{
${ }^{25}$ Tradução nossa: "Meu livro de versos filosóficos começa a me dar nojo."
} 
56). É a partir desse momento que Laforgue passa do lirismo pessoal e filosófico para a expressão livre, em que não há nada mais "levado tão a sério".

A confissão passa a ter origem em diversos tipos, caricaturas que não mais representam apenas um único enunciador. Em seus lamentos, Laforgue traz para sua poesia sistemas culturais de referência usados para conferir alguma consistência objetiva à linguagem livre da imaginação, como no caso de suas apropriações de seres da mitologia clássica ou personagens da Commedia dell'Arte italiana, sobretudo o Pierrot, reinterpretados ou combinados de forma sincrética.

Pode-se afirmar, então, que Les Complaintes, como o início da construção dessa estética particular por meio de seus labirintos e rupturas, visava corresponder à exigência de um renascimento poético, de algo que Laforgue chamava de "o original a qualquer preço". Em uma carta a sua irmã, Marie, datada de 14 de maio de 1883, o poeta fala de sua nova estética, ao mesmo tempo em que confessa seu desejo para o próximo livro:

Aujourd'hui que je suis plus sceptique et que je m'emballe moins aisément et que d'autre part je possède ma langue d'une façon plus minutieuse, plus clownesque, j'écris de petits poèmes de fantaisie, n'ayant qu'un but: faire de l'original à tout prix. ${ }^{26}$ (LAFORGUE, 1995 [1883], p. 51)

Para a elaboração de tal originalidade, Laforgue acrescentou ao coloquialismo de seus versos o prazer da bufonaria verbal e a ironia de si mesmo como forma de mediar as realidades grosseiras e as fantasias delicadas.

Veremos que a busca do novo e da inovação constante é, antes de ser pesquisa e exploração cognitiva por meio da linguagem, uma negação sistemática do senso comum, uma ofensa ao bom senso e à ponderação, rechaço das ideias herdadas e da própria comunicação. Alfonso Berardinelli diz

${ }^{26}$ Tradução nossa: "Hoje, que sou mais cético e que me entusiasmo menos facilmente, e por outro lado, domino minha língua de maneira mais minuciosa, mais clownesca, escrevo poemas breves de fantasia, com um único objetivo: produzir algo original a qualquer preço." (Carta de Laforgue a sua irmã, Marie, em 14 de maio de 1883, in CEuvres Complètes. Paris: L'Âge d'Homme, 1995. 
que há nessa busca pelo novo uma "tentativa provocadora de subversão do inconsciente" (BERARDINELLI, 2007, p. 139), onde a obscuridade toma a forma de uma linguagem inaceitável, um insulto ao público, ou uma agressão e recusa da sociedade presente.

É neste instante que o poeta francês depara uma difícil relação com a linguagem. Sua nova poética nascerá após uma experiência de solidão e sofrimento inconfessáveis. Esse percurso tortuoso, em busca de sua originalidade e singularidade artística resultará em uma ironia de autorreconhecimento, que será desenvolvida mais adiante neste trabalho, e que para além de uma autocrítica, será uma forma de expressão particular para "el desdichado" em Laforgue.

Vejamos a seguir, na análise abaixo, o que tentaremos aprofundar nesse percurso anterior aos lamentos, para compreendermos melhor a renovação criadora de Laforgue.

O pontapé inicial dessa nova poética foi Chanson du petit hypertrophique (1882), que já traz o contraste da confidência séria com uma autenticidade impecável em que o poeta nega ou dissimula a tradição com uma estrutura que se constrói a partir de uma característica marcante da linguagem de rua: a elisão que omite o som da letra "e" das palavras, representado no poema pelo apóstrofo:

$\begin{array}{ll}\text { C'est d'un' maladie d' cœur } & \text { Foi de uma doença do coração } \\ \text { Qu'est mort', m'a dit l' docteur, } & \text { Que morreu, me disse o doutor } \\ \text { Tir-lan-laire ! } & \text { Tir-lan-laire ! } \\ \text { Ma pauv' mère } & \text { Minha pobre mãe } \\ \text { Et j'irai là-bas, } & \text { E vou até lá } \\ \text { Fair' dodo z'avec elle. } & \text { Fazer naninha junto dela. } \\ \text { J'entends mon cœur qui bat, } & \text { Ouço meu coração que bate, } \\ \text { C'est maman qui m'appelle ! } & \text { É mamãe que me chama! }\end{array}$

On rit d' moi dans les rues, Riem de mim nas ruas

Des mes min's incongrues

Da minha aparência 
La-i-tou

D'enfant saoul ;

Ah ! Dieu! C'est qu'à chaqu' pas

J'étouff', moi, je chancelle !

J'entends mon cœur qui bat,

C'est maman qui m'appelle !

Aussi j' vais par les champs

Sangloter aux

couchants,

La-ri-rette !

C'est bien bête.

Mais le soleil, j' sais pas,

M' semble un cœur qui

[ruisselle!

J'entends mon cœur qui bat,

C'est maman qui m'appelle !

Ah! si la p'tit' Gen'viève

Voulait d' mon cœur qui s'

[crève.

Pi-lou-i !

Ah-oui !

J' suis jaune et triste, hélas !

Elle est ros', gaie et belle !

J'entends mon cœur qui bat,

C'est maman qui m'appelle !

Non, tout l' monde est méchant,

Hors le cœur des couchants,

Tir-en-laire!

Et ma mère, [inconveniente

La-i-tou

De criança atordoada

Ah! Deus! É que a cada passo

Eu sufoco, eu vacilo

Ouço meu coração que bate,

É mamãe que me chama!

Vou pelo cemitério

Soluçar ao pôr do sol,

La-ri-rette!

E muito besta.

Mas o sol, não sei

Me parece um coração que

[escorre

Ouço meu coração que bate,

É mamãe que me chama

Ah! se a pequena Geneviève

Quiser que meu coração se

[afunde

Pi-lou-i!

Ah-sim!

Sou amarelo e triste, que azar!

Ela é rosa, feliz e bonita!

Ouço meu coração que bate,

É mamãe que me chama!

Não, todo mundo é malvado,

Fora o coração dos mortos,

Tir-en-laire!

E minha mãe, 

Et j' veux aller là-bas
E vou até lá
Fair' dodo z'avec elle...
Fazer naninha junto dela...
Mon cœur bat, bat, bat, bat...
Meu coração bate, bate, bate, [bate...
Dis, Maman, tu m'appelles $?^{27}$
Diga Mamãe, você me chama?

O poema é formado por cinco estrofes de oito versos que seguem a mesma divisão silábica para dar forma à canção, estrutura típica da tradição popular, com o jogo de rimas simples (AABB/ ABAB). Todo o texto se dá no presente do indicativo, trazendo ao leitor certa imediatez da cena ou ainda, a função de interlocutor daquele "je" que fala. A cantiga possui um refrão que está presente nos dois últimos versos de cada estrofe e teria a função de apaziguar as inquietações, trazendo certo tom de resignação em meio à angústia da perda. Vejamos para qual cena o eu lírico nos remete: nesta canção, ouvimos a voz de um sujeito que acaba de receber a notícia da morte de sua mãe.

As reações desse eu lírico parecem ser àquelas de alguém desesperado, que diz coisas absurdas que não condizem com a situação real, como se estivesse em estado de choque "Et j' veux aller là-bas/ Fair' dodo z'avec elle". A linguagem fragmentada será o espelho de um sujeito em busca de um recomeço, alguém que se vê diante da morte de sua mãe e que luta para reencontrar o que se perdeu.

As repetições são marcas da canção, e no caso acima, a palavra "cœur" [coração], "mère" [mãe] ou "maman" [mamãe] são constantemente evocadas, como uma espécie de refrão ritmado. O vocabulário próprio das canções populares e da oralidade nos traz o eco da dor sentida pelo "je": cada batida de seu coração, marcada por um ritmo do refrão, indica um chamado de sua mãe, ou seja, quando o sujeito ouve as batidas de seu coração significa ainda há vida: J'entends mon coeur qui bat,/ C'est maman qui m'appelle...". Além disso, o poeta utiliza-se da repetição de expressões onomatopéicas, típicas das canções populares: "Tir-en-laire", "Pi-lou-i", "La-ri-rette".

\footnotetext{
27 "Chanson du petit hypertrophique", in CEuvres Complètes, 1995 [1882].
} 
Na segunda estrofe podemos ver a posição deste "je" diante do mundo: rejeitado, motivo de gozação, um "enfant saoul" [filho repudiado], estrangeiro, que não reconhece seu lugar entre os outros: "On rit d' moi dans les rues,/ des mes min's incongrues" [Riem de mim nas ruas/ da minha aparência inconveniente]. A cada passo ele sufoca, vacila: "j'étouff', moi, je chancelle", como se algo pesasse em seus ombros, algo que o faz quase cair, mas de repente, segue novamente o refrão: "J'entends mon coeur qui bat,/ C'est maman qui m'appelle", como prova de que ainda há vida e de que é cedo para se entregar à morte. Os versos do refrão estabelecem uma comunhão entre o viver e o morrer, como um elo delicado entre o coração que pulsa e a morte refletida no rosto de sua mãe.

Ao mesmo tempo, podemos dizer que esse elo, essa "escuta" podem ser comparados à busca pelo "objeto perdido" sugerido por Julia Kristeva, em Sol negro. A incorporação ${ }^{28}$ desse "objeto que se perdeu", representado aqui pela perda de sua mãe, restabelece a questão fundamental para esta fase do poeta: a busca por algo que não se recupera, uma linguagem "morta", que não se alcança, mas que deve morrer para nascer de novo, absolutamente renovada, original.

Em seu capítulo dedicado ao poema de Nerval, Julia Kristeva discorre sobre a questão da busca por uma "coisa" ou "objeto" perdidos que seriam o motivo fundamental para essa eterna procura, inquietante, como no caso da canção acima. Podemos dizer que para o poeta "desdichado", "deserdado", essa privação de "algo" não se trata apenas de uma privação material, mas sim "de um território não nomeável" que

[...] se poderia evocar ou invocar estranhamente do exterior, de um exílio constitutivo. Essa "qualquer coisa" seria anterior ao "objeto" discernível: horizonte secreto e intocável de nossos amores e nossos desejos, para o

${ }^{28}$ Em Vocabulário da Psicanálise, de Jean Laplanche e Jean-Bertrand Pontalis, encontramos a seguinte definição para o termo "incorporação": "Processo pelo qual o indivíduo, segundo um modo mais ou menos fantasmático, faz penetrar e conserva um objeto no interior de seu corpo. [...] Constitui o protótipo corporal da introjeção e da identificação." (Laplanche \& Pontalis, 1979, pp. 309-10) 
imaginário ela toma a consciência de uma mãe arcaica que, no entanto, nenhuma imagem precisa consegue englobar. (KRISTEVA, 1987, p. 136)

Dessa insatisfação constante, o reconhecimento da perda e da dor se dá nas próximas estrofes. Porém, há uma reviravolta na maneira como ele reage a esse reconhecimento. Na terceira estrofe, o poeta diz que também se entregará aos "champs" [cemitério] para chorar a morte de sua mãe, mas o verso seguinte traz um elemento inusitado: "C'est bien bête".

Neste verso, o poeta utiliza-se da ironia transgressora que, a partir de então, o acompanhará como marca de sua poética renovada. Esta ironia, além de transgressora, no sentido de que o sujeito afirma ser "muito besta" chorar pela morte de sua mãe, é sinal do desamparo profundo pelo qual ele afirma reconhecer-se perdedor, abandonado e doente, tanto no que diz respeito à mãe ou à "p'tit' Gen'viève": "Je suis jaune et triste, hélas !/ Elle est ros', gaie et belle !". E, também, é fortemente carregada pelo ressentimento de ainda estar vivo, o que intensifica o seu aspeco sarcátisco.

Como resultado de sua dor, a ironia ultrapassa a autocrítica. É a ferramenta que torna possível a morte e renovação simultânea de sua linguagem. A batida rítmica do refrão, que até o momento teria a função de serenar as angústias, é bruscamente alterada nos últimos versos: "Mon cœur bat, bat, bat, bat.../ Dis, Maman, tu m'appelles?". O ritmo acelerado causado pela repetição do verbo "battre" [bat, bat, bat, bat...] dá a sensação de que "je" está em vias de sofrer de um ataque do coração. Nessas batidas de entrega, em que imaginamos que enfim o sujeito realizará seu desejo de morte para o reencontro definitivo com sua mãe, com o "objeto perdido", somos interrompidos por uma pergunta desesperada, de incerteza ou dúvida: "Dis, Maman, tu m'appelles?". Ou também é possível dizer que o filho suplica à mãe que ela o chame, para que esse chamado o leve ao seu encontro com a morte.

Este final desolador cai como uma armadilha para o "je" e para nós leitores. A sensação de desamparo e de tristeza é fortemente comunicada como representação da realidade vazia que pesa sobre os olhos do sujeito.

Ficamos assim próximos da função da poesia nesta fase de Laforgue: é aqui que seu contato com a morte representa a 'chave' de seu encontro com a nova poética. Como o reverso do fim, a poesia é a força necessária para a 
sobrevivência da linguagem. Conforme afirma Yudith Rosenbaum, para Freud, "as figurações possíveis da pulsão de morte devem, então encontrar um outro canal para registrar esse "não ser'" (ROSENBAUM, 2002, p. 132). O registro do imaginário, da escrita é o único meio de dar testemunho desse hiato, desse branco que é a morte para o inconsciente.

O fundo melancólico e de luto percorrerá toda a obra de Laforgue, e será visível, no decorrer de sua produção, como a ironia será uma ferramenta para o reconhecimento desse luto, dessa perda, diferentemente do que tentaremos mostrar em Bandeira. Para tentarmos esclarecer de que forma se dá essa relação em Bandeira, vejamos abaixo "O menino doente":

O menino dorme.

Para que o menino

Durma sossegado,

Sentada a seu lado

A mãezinha canta:

- "Dodói vai-te embora!

"Deixa o meu filhinho.

"Dorme... dorme... meu..."

Morta de fadiga,

Ela adormeceu.

Então, no ombro dela, Um vulto de santa, Na mesma cantiga, Na mesma voz dela, Se debruça e canta:

- "Dorme meu amor.

"Dorme , meu benzinho..."

E o MENINO dorme. ${ }^{29}$

29 "O menino doente", in O ritmo dissoluto, 1924. 
No poema o "eu" bandeiriano volta à infância para resgatar uma cena íntima: no quarto, sua mãe canta para que ele durma tranquilo. Neste poema percebemos que não há ironia e sim uma tentativa de resgatar o espaço infantil do qual o poeta se sente excluído e que só pode ser revisitado pela memória. Vale lembrar que em toda a obra de Bandeira, a infância se destaca como um elemento que define uma dinâmica de perdas e reencontros. Para o poeta, o mundo infantil é o espaço da saúde, da ingenuidade, da simplicidade, onde há magia e pureza. Ao selecionarmos este poema tentaremos identificar o "desdichado" em Bandeira e qual a relação dessa etapa de sua produção, a de preparação para a morte e convivência com a dor; com a etapa seguinte, de constituição de uma ironia própria, mais claramente visível em Libertinagem.

$\mathrm{Na}$ estrutura formal do poema, o sono representa a moldura de proteção do menino. Abre e fecha o poema em dois versos que se repetem: "O menino dorme." e "E o MENINO dorme." É também ele que traz ao menino a possibilidade de sonhar, ou ainda, o protege dos acontecimentos externos. Para seu sono "tranquilo", a mãe então canta: "Dodói vai-te embora!/ "Deixa o meu filhinho." Da mesma maneira que em "Chanson du petit hypertrophique", o poeta brasileiro se utiliza de uma canção popular, no caso, uma canção de ninar, para embalar o sono do menino. $O$ recurso da oralidade confere uma carga ainda mais intimista à cena descrita.

$O$ ato de dormir coloca o menino em segundo plano. Toda a narrativa se dá, nos primeiros versos, por meio das ações da mãe. Para Davi Arrigucci Jr., os recursos narrativos denotam "a importante aproximação técnica do poeta brasileiro às formas de um estilo prosaico moderno". Essa prática consistiu, principalmente, como afirma o crítico, "no contato com a experiência do verso de Guy-Charles Cros ou de Jules Laforgue" (ARRIGUCCI, 1987, p.16).

Ao final da segunda estrofe, quando a mãe 'falha' na canção, ou seja, quando seu canto é interrompido pelo cansaço: "'Dorme... dorme... meu...”, um acontecimento inusitado ocorre. A utilização das reticências e a abertura de uma nova estrofe, com apenas dois versos, trazem ao poema a sensação rítmica de pausa. Tal recurso é utilizado para intensificar a ideia de solidão da qual o "menino" irá sofrer. A introdução da estrofe pela palavra "Morta" é angustiante. A mãe está ausente, "adormeceu". 
Cabe dizermos aqui que, para Bandeira, nesse espaço ingênuo do menino que dorme ouvindo os acalantos da mãe, a infância subsiste de forma intensa sob a aparência do homem adulto. O mesmo ocorre no poema "Versos de Natal", de Lira dos Cinquent' anos, no qual, embora mais tardio, lemos os seguintes versos: "Descobririas o menino que sustenta esse homem,/ $O$ menino que não quer morrer". Dessa maneira, é possível dizer que, ao reviver os caminhos da infância, Bandeira encontra o segredo da emoção poética. Há uma passagem no Itinerário de Pasárgada que nos permite perceber esse encontro:

O que há de especial nessas reminiscências [...] é que, não obstante serem tão vagas, encerram para mim um conteúdo inesgotável de emoção. A certa altura da vida vim a identificar essa emoção particular com outra - a de natureza artística. Desde esse momento, posso dizer que havia descoberto o segredo da poesia, o segredo do meu itinerário em poesia. (BANDEIRA, 1984 [1954], p. 17)

Em "O menino doente" ficamos comovidos ao apreendermos que a solidão vivida pelo "eu" virá após o sono tranquilo, ou seja, em sua vida adulta. A ausência e o desamparo que virão mais tarde coabitar o futuro do poeta ganham força de reflexos profundos em sua atitude, como por exemplo, em sua atitude humilde, espelhada nos poemas.

Diferentemente da "Chanson" de Laforgue, não se trata aqui de um apelo desesperado do "eu" por algo/ alguém que se perdeu. Aqui, o "desdichado" não está completamente desamparado: essa outra figura materna, "Um vulto de santa", mantém a mesma tranquilidade para o sono do menino: "Na mesma cantiga,/ Na mesma voz dela". Contudo, essa substituição pode nos proporcionar uma leitura dupla: o desamparo se remete à ausência imediata da mãe, ela adormeceu. Mas, a substituição da figura materna pela santa previne o que poderia ser insuportavelmente doloroso para o menino. Além de sugerir que ele nunca estará só, reafirmando, assim, a positividade da poética banderiana.

Diante da ausência da imagem reside o paradoxo da visualidade: "poder sempre acalmar a angústia suscitada em nós pela ausência, garantindo 
que o objeto amado esteja inteiramente ao alcance de nosso olhar e que nos reflita em nossa identidade" (PONTALIS, 1991, p. 205).

Perder de vista: acaso isso não seria o que há de mais insuportável na perda? Como afirma Pontalis, em seu ensaio, cada perda anunciaria, no outro, uma "retirada absoluta do amor", e, "em nós", por outro lado, "a inquietação de uma fragilidade essencial: não ser capaz de amar o invisível". (DIONISIO, 2011, p. 123)

Em outras palavras, pode-se dizer que no sujeito do olhar nasce a premência de não perder de vista, no caso do "menino doente", mas também de não se fazer perder de vista pelo objeto, como no caso do "Petit Hypertrophique" de Laforgue. A perda seria, nesses dois casos, o fim e o (re)começo de um novo caminho para a produção poética.

${ }^{30}$ Para concluirmos esta ideia da falta permanente, utilizamos o ensaio de J.-B. Pontalis, "Perder de Vista", do livro Perder de Vista: Da Fantasia de recuperação do objeto perdido. Rio de Janeiro: Zahar, 2003, p. 205. 
CAPÍTULO 3 | UM CONCEITO VERTIGINOSO 


\subsection{Breve conceito de ironia}

De acordo com o que pudemos observar no capítulo anterior, a dor e a experiência com a morte foram traços marcantes para a construção da matéria poética de Jules Laforgue e Manuel Bandeira. Vimos que, ainda profundamente ligados às tradições relativas a cada época, os poetas utilizaram-se do tema da morte em seus primeiros livros como fonte de superação e de aprendizado.

Nesta pesquisa, pretendemos propor que a transformação do tema da dor se dará em ambas as obras a partir do encontro particular de cada poeta com a ironia. Veremos que o recurso será utilizado ora como forma de ruptura das tradições, ora como distanciamento e reação às experiências da vida, ligadas à morte, à doença e à solidão.

Para tanto, neste capítulo discutiremos de que forma o recurso da ironia esteve presente nas duas obras e como este conceito se torna um "ponto de convergência" na produção poética de Bandeira e Laforgue. Proporemos que a ironia servirá, então, como uma espécie de linha tênue entre a tragédia e - sarcasmo, como um ponto de equilíbrio onde não se permite ser exageradamente melancólico nem carregado de humor. E veremos que, embora relacionada a um movimento de ruptura, de crítica em relação a valores pré-estabelecidos, a ironia esteve presente desde o início da trajetória lírica de ambos os poetas.

Mas, antes de traçarmos as diferenças ou correspondências entre a manifestação desse conceito nos poemas, é necessário retomar brevemente a origem desse recurso e tentar descobrir o que de fato é a ironia. "Tentar" porque durante a pesquisa observamos que, por diferentes razões, trata-se de um conceito instável, amorfo e vertiginoso. Não quer dizer o mesmo que dizia há séculos atrás. Não significa a mesma coisa em todos os lugares, nas ruas ou nas bibliotecas; para um historiador e para um crítico literário pode ser um conceito completamente adverso. Dois críticos literários podem estar totalmente de acordo em relação a uma mesma obra, mas um pode considerála "irônica", o outro "satírica", ou ainda "cômica", "humorística", "paradoxal", "dialética" ou "ambígua". 
Historicamente, a noção que apreendemos do conceito de ironia é o resultado da aplicação do termo feita ao longo dos séculos, sem levar em consideração, muitas vezes, a evolução semântica desordenada desse mesmo conceito; sem procurar distingui-lo ou analisá-lo diante de suas possíveis variedades. Desta forma, ao identificarmos a imprecisão do conceito de ironia e para compreender como os poetas se utilizaram desse recurso estilístico em seus poemas, será necessário definir, mesmo que brevemente, a origem e a evolução do conceito, partindo da filosofia clássica até o Romantismo alemão.

Neste capítulo, tentaremos pensar o conceito de ironia e como articular sua complexidade ao campo da poesia. Para tanto, cabe antes apresentarmos uma breve consideração sobre a história do conceito. Naturalmente, daremos ênfase ao que poderá ser resgatado para as análises nas seções seguintes.

\subsection{1 (Se) perguntar vale a pena?}

Se levarmos em consideração certas transformações ocorridas na arte, mais especificamente na literatura após o romantismo alemão, veremos em que medida a ironia será para o artista moderno um dos mais importantes recursos herdados dessa reflexão. É evidente, contudo, que a ironia é um conceito anterior ao movimento romântico e já era aplicada em vários estudos e obras que envolviam não só a literatura, mas também a filosofia e as artes plásticas.

A começar por Sócrates, na Antiguidade Clássica que inaugurou o conceito de ironia em seus próprios ensinamentos, ou seja, como metodologia; assim como um dos seus discípulos mais célebres, Aristóteles, que fez a aplicação desse conceito nos estudos do discurso, em suas obras sobre a Poética, a Ética e a Retórica. Sabemos, portanto, que a ironia não é um termo de origem literária, mesmo que possamos encontrar registros de sua passagem pela literatura desde os primórdios, como por exemplo, na poesia épica de Homero até a poesia lírica de Arquíloco.

O conceito de ironia teve sua primeira aparição histórica na Antiguidade Clássica, por meio dos escritos de Platão a respeito de seu mentor, Sócrates. Para este filósofo, ora mítico, ora figura central da filosofia 
antiga, a ironia é uma determinação da subjetividade. É a partir dessa determinação que se modulam as diversas possibilidades do discurso e, consequentemente, de pontos de vista. Assim, quando há disponibilidade para a variação do pensamento, torna-se possível a distinção entre o que se pensa e o que de fato é dito.

Essa determinação da subjetividade será o fundamento central da metodologia socrática conhecida por maiêutica. A maiêutica tem como significado "dar a luz", o que corresponde, de certa forma, a um "parto intelectual", uma procura do homem pela verdade. Sócrates conduzia esse "nascimento" em duas etapas: na primeira, levava seus discípulos ou interlocutores a duvidar de seu próprio conhecimento a respeito de um determinado tema; depois, Sócrates os levava a conceber por si mesmos uma nova opinião a respeito do assunto em questão. Por meio de questões simples, inseridas dentro de um contexto determinado, a maiêutica dá à luz a ideias complexas. Baseia-se no princípio de que o conhecimento é latente, pois o sujeito procura extrair da sua alma o conceito que nela permanecia oculto, desenvolvendo seu próprio pensamento, ou seja, reencontrando, por si mesmo, conhecimentos que já possuía sem o saber.

Desta forma, a ironia estava inserida nesse método de maneira central: correspondia ao modo como todo o questionamento era conduzido e, a partir desse recurso, era possível delimitar um conceito, contradizê-lo e refutá-lo. 0 verbo grego que originou a palavra ironia (eirein) significa "perguntar". Sabemos, contudo, que o objetivo não era constranger o interlocutor, mas sim purificar seu pensamento, desfazendo-o de ilusões. A ironia socrática não foi concebida com o intuito de ridicularizar, mas de fazer irromper da aporia, ou seja, do impasse sobre a verdade, o entendimento.

Percebemos, então, que a ironia possui em sua origem um caráter de ruptura, de quebra de valores pré-estabelecidos. Esse traço do conceito irônico também pode ser vislumbrado nos diálogos estabelecidos entre Sócrates e Trasímaco quando ambos refletem sobre a essência do conceito de justiça na República. É quando a ironia socrática revelará seu potencial de questionamento, demolindo as certezas sobre determinados conceitos. As aparências, equivocadamente consideradas pontos determinantes das 
definições conceituais são, na verdade, os pontos de partida para os jogos estabelecidos entre significantes e significados. Nesses diálogos, Trasímaco aprende a refletir sobre tal equívoco, a partir do momento em que desafia Sócrates contestando que o "justo não é senão a vantagem do mais forte". (PLATÃO, 1975, p.19).

A conclusão da dança dos silogismos socráticos é a de que "o justo revela-se-nos, portanto, bom e sábio e o injusto ignorante e mau". (PLATÃO, 1975, pp. 33-35). É difícil sintetizar as argumentações de Sócrates e Trasímaco em virtude do risco de se perder as nuances do jogo irônico desenvolvido no transcorrer dos diálogos. Mesmo assim, nestas passagens dialógicas a respeito do conceito de justiça, é importante observar as voltas e reviravoltas elaboradas por Sócrates na refutação do raciocínio de Trasímaco. Não se trata apenas da demolição pura e simplesmente dos alicerces lógicos de seu interlocutor, mas sim da aparência de verdade que a definição de Trasímaco portava sobre o conceito da justiça e, por consequência, de seu oposto, a injustiça.

Resumidamente, ironia e maiêutica constituíam, por excelência, as principais formas de atuação do método dialético de Sócrates, desfazendo equívocos e evidenciando nuances que permitiam a introspecção e a reflexão interna, proporcionando a criação de juízos cada vez mais fundamentados no logos ou razão.

Porém, não foram poucas, ou mesmo menores, as objeções feitas ao método de Sócrates. Para Platão, o termo eironea teria o significado de "uma forma lisonjeira, abjeta de tapear as pessoas" (PLATÃO, 1975, P. 156). Já para Demóstenes, um eiron era aquele que, alegando incapacidade, fugia de suas responsabilidades como cidadão. Apenas séculos mais tarde, Soren Kierkegaard afirmará que a auto-humilhação final de Sócrates teve o objetivo consciente de se exaltar diante dos pobres de espírito que são dominados pela opinião e pensam, equivocadamente, que dominam plenamente as essências dos conceitos. Kierkegaard reconhece que

este é justamente o fino jogo de músculos da ironia. A circunstância de que ele (Sócrates) tem consciência de que nada sabe o alegra e o deixa infinitamente leve, enquanto os outros se matam por seus tostões (...) 
Quanto mais ele se alegra por causa deste nada, não como resultado, mas como infinita liberdade, tanto mais profunda é a ironia" (KIERKEGAARD, 1991, p.189).

A alegria de Sócrates está justamente relacionada à força que a ironia possui em produzir novos significados aos conceitos discutidos. Foi de extrema importância a percepção de Kierkegaard em reconhecer que a capacidade de autocrítica de Sócrates o eximia de se identificar como o senhor absoluto dos conceitos, ao mesmo tempo em que tal constatação o habilitava a enveredar novamente pelos caminhos e descaminhos do conhecimento.

É a partir desta perspectiva que a dimensão do conceito de ironia se revela uma

tentativa de "palavração" [Verspralichung] do mundo. A este respeito, a ironia remete ao mundo real, mas como uma tentativa de palavração do mundo na forma de uma réplica simultânea. E assim ela se refere aos mundos possíveis" (JAPP, 1983, p.18).

De forma correspondente, a poesia também revela possibilidades para a construção de mundos possíveis. A relação com a escrita dá ao poeta substrato necessário para a elaboração de um saber oculto tanto para aquele que compõe tanto para aquele que lê os versos. O leitor, então, tem função primordial no jogo da ironia: apenas ele é capaz de perceber que a linguagem não tem significados fixos e que o texto pode lhe apresentar armadilhas e enganos dos quais, eventualmente, deverá participar. Isso porque um autor escreve para ser lido, mesmo que seja apenas por ele mesmo.

A partir dessa tentativa de "palavração" do mundo, é possível considerar que a pergunta, a interrogação interpretativa que alguns poemas nos oferecem são, de certa forma, uma herança desse modo de conceber o mundo ou, ainda, de transformá-lo aos olhos do leitor. Vejamos como exemplo duas estrofes, uma de Laforgue e a outra de Bandeira, que se encaixam no método do questionamento daquilo que se "finge" não saber e cuja resposta é destinada a ser, em parte, responsabilidade do leitor: 
Maintenant! pourquoi ces complaintes ?

Gerbes d'ailleurs d'un défunt moi

Où l'ivraie art mange la foi ?

Sot tabernacle où je $\mathrm{m}$ ' éreinte

À cultiver des roses peintes ?

Pourtant ménage et sainte-table !

Ah! Ces complaintes incurables,

Pourquoi ? Pourquoi ? ${ }^{31}$

Um dia serei feliz?

Sim, mas não há de ser já:

A Eternidade está longe,

Brinca de tempo-será. ${ }^{32}$

As perguntas que ecoam dos poemas propõem uma reflexão interpretativa que leva o leitor a inúmeras possibilidades e descobertas. Mesmo que uma resposta se apresente, há também a dúvida ou a abertura para novas conclusões. As experiências vividas tanto pelo "eu lírico" quanto pelo leitor é que definirão os caminhos dessa estrada sinuosa da palavra poética. $O$ objetivo da ironia, portanto, nem sempre será o da comicidade, mas sim o de inebriar, sacudir e reverter aquilo que se diz definitivo.

\subsubsection{De perto e de longe: do Romantismo alemão à modernidade}

Aristóteles, em sua Ética a Nicômaco, conceituará a eironea [ironia] como uma espécie de dissimulação autodepreciativa superior ao seu oposto, a alazoneia, ou dissimulação presunçosa. A modéstia, ligada à eironea, mesmo que simulada, ainda era melhor que a ostentação, por sua vez ligada a alazoneia. É neste momento que o termo, antes considerado apenas para

31 Tradução nossa: "Agora! Por que esses lamentos?/ Gérberas de um eu-defunto/ Onde a bêbeda arte devora a fé?/ Cômoda idiota sobre o qual eu me canso/ De cultivar rosas pintadas?/ Portanto basta!/ Ah! Esses lamentos incuráveis,/ Por quê? Por quê?". "Complainte des complaintes", in Les complaintes, 1885.

${ }^{32}$ Estrofe extraída de "Tempo-será", in Belo, Belo, 1948. 
denominar um tipo de comportamento, passa a ser reconhecido por Cícero como um recurso da retórica: censurar por meio de um elogio irônico, ou elogiar por meio de uma censura irônica. A este recurso retórico reconhecido por Cícero, Quintiliano ainda acrescenta a possibilidade de conceber a ironia como uma figura de linguagem.

Foi assim que, durante mais de duzentos anos na Europa moderna, o termo ironia reduziu-se a uma figura de linguagem que, em linhas gerais, foi definido como "algo que diz uma coisa, mas significa outra", como uma forma de "elogiar a fim de censurar ou vice-versa" ou ainda "zombar" ou "escarnecer". A palavra ironia também passou a ser empregada para significar dissimulação, mesmo que a dissimulação não irônica, os subentendidos ou ainda, a paródia.

Foi apenas no final do século XVIII e no começo do XIX que o conceito (re)assumiu outros significados. Isso ocorreu diante da grande transformação proporcionada pelo Romantismo alemão em relação à visão de mundo provinda dos séculos anteriores. Em 1797, Friedrich Schlegel, faz a seguinte observação: "Petrarca também se utiliza da ironia romântica". Desde a República de Platão até os escritos de Schlegel, a ironia fora considerada essencialmente sob sua forma retórica; é a partir daí, então, que a ironia renasce na literatura e na filosofia. Para o filósofo alemão, a ironia será considerada um quasi-sinônimo do próprio movimento romântico.

Contudo, para fundar sua teoria, Schlegel faz uso da dupla tradição da ironia - de um lado, a tradição retórica; de outro, Sócrates. Da retórica, retoma o elemento essencialmente negativo e constitutivo de toda ironia: a atitude de contradição e de revolta que cabia perfeitamente aos objetivos filosóficos e revolucionários de Schlegel. E, da tradição filosófica que remonta à ironia socrática, Schlegel retém a dissimulação, perfeita expressão do indizível:

L'ironie socratique est l'unique feinte foncièrement invonlontaire et pourtant foncièrement lucide. Il est aussi impossible de la simuler que de la dévoiler. Pour celui qui ne l'a pas, elle demeure une énigme. [...] Toute en elle doit être plaisanterie, et tout doit être sérieux, tout offert à coeur ouvert, et profondément dissimulé. (Lyceum, 108) ${ }^{33}$

${ }^{33}$ Tradução nossa: "A ironia socrática é a única fenda profundamente involuntária e, por isso, profundamente lúcida. É tão difícil simulá-la quanto desmascará-la. Para aquele que não a 
A base da posição filosófica adotada por Schlegel concentra-se, portanto, sobre uma concepção do universo considerado como um caos. Dentro dessa perspectiva, a ironia passa a ser uma espécie de consciência deste caos: "A ironia é a consciência clara da mobilidade eterna, de um caos que corre em direção ao infinito" (Idées, 69).

Em um mundo feito de contradições, Schlegel defende a ideia de que 0 espírito humano não é capaz de alcançar o Absoluto. Contudo, o homem não renunciará a seus esforços: buscará a ordem do mundo onde há intuição, ou seja, na arte. De acordo com ele, ao organizar o caos do universo, o artista vai mais longe que o filósofo. Apesar da consciência de sua própria finitude, a arte conseguirá aproximar o homem do Absoluto na mesma medida em que a ironia estará integrada à sua arte.

Seule la poésie là encore peut s'élever à l'hauteur de la philosophie ; elle ne prend pas appui, comme la réthorique, sur des simples passages ironiques. II y a des poémes, anciens et modernes, qui exhalent de toutes parts et partout le souffle divin de l'ironie. Une véritable bouffonnerie transcendentale vit en eux. $\left(\right.$ Lyceum, 42) ${ }^{34}$

Esse fragmento denota que a ironia também se situa no leitor. Isto porque, quando Schlegel afirma que existem textos "anciens" (antigos), nos quais a ironia romântica é identificada, o anacronismo sublinhará aquilo que já estava implícito no comentário a respeito de Petrarca. Desta forma, o leitor é o responsável por estimular nas obras a "bouffonnerie transcendentale" [bufonaria transcendental]. Como vimos anteriormente, trata-se de uma demanda de engajamento endereçada ao leitor, pois, se a ironia é um modo de escrita, ela também deve ser considerada como um modo de leitura. A dinâmica do conceito de ironia apenas existe no poema se o leitor participar

reconhece, ela permanece um enigma. [...] Tudo nela deve ser brincadeira e tudo deve ser sério, tudo oferecido de coração aberto e absolutamente dissimulado."

${ }^{34}$ Tradução nossa: "Somente a poesia pode também se elevar à altura da filosofia, e não está fundada em passagens irônicas, como a retórica. Há poemas antigos e modernos que respiram, do início ao fim, no todo e nas partes, o divino sopro da ironia. Neles vive uma bufonaria realmente transcendental." 
ativamente da constituição de um sentido. Portanto, para o romantismo alemão, a ironia retoma a ideia de não ser apenas o princípio implícito que guia o artista em suas leituras e em suas composições, ela também será o ideal de vida e de arte do homem moderno.

Schlegel afirma, então, que a ironia é inerente à arte. Para escrever, o artista consciente precisa ser criativo e crítico, subjetivo e objetivo, emocional e racional, inconscientemente inspirado e conscientemente artista. Diante da impossibilidade de se fazer um relato verdadeiro ou completo da realidade, o que resta ao artista é incorporar ao seu trabalho a consciência de sua irônica posição diante do mundo.

Afirmação da ilusão das coisas e, antes de tudo, da ilusão da própria arte, a ironia romântica busca a reprodução infinita de imagens a se refletirem de espelho em espelho. Por isso seus motivos recorrentes são o da mascarada, do especular e do duplo. Sua função é mergulhar o leitor num equívoco benfeitor que o faz perceber a diferença entre o eu que vê, o eu que atua e a transparente opacidade da máscara que, se for perfeita demais, não se distinguirá de falsidade (é preciso ter consciência da máscara) (DUARTE, 2006, p. 45).

Segundo Lélia Parreira Duarte, a ironia romântica só é possível quando se desfaz a ilusão de que a obra corresponde a uma "realidade". A obra, portanto, se afirmará na maior parte das vezes não apenas como paródica, mas sim "autoparódica". Nela o autor apresenta a consiência de ser o seu primeiro leitor, comenta e julga o que escreve, rompendo a ilusão da representação através da parábase. Ao intervir, o autor sugere uma ultrapassagem de sentido, que passa a ser relativo e incompleto. A partir disso, tudo pode ser justificativa para a criação literária.

Jules Laforgue foi mestre nesse jogo de intervenções entre o sujeito lírico e o leitor. Em seus poemas, somos provocados a entrar e sair do universo proposto nos versos, o que de certa forma nos aproxima daquele "je" como espécie de cúmplices de uma mesma experiência, mas ao mesmo tempo distanciados pela realidade e pela ilusão da obra. O que nos remete também à Pasárgada de Bandeira, o mundo ilusório construído para que todos 
pudéssemos sonhar juntos, mesmo que, em seguida, a queda para o retorno à realidade seja desastrosa.

O desenrolar dessas teorias e a absorção do conceito de ironia proposto por Schlegel trouxe inúmeros desafios para as gerações posteriores. Tomamos como exemplo o filósofo José Ortega y Gasset que em seu reconhecido ensaio La deshumanización del arte (1925), ilustra perfeitamente os problemas de compreensão ligados à ironia romântica e o tempo necessário para que ela encontrasse novos caminhos além da Alemanha.

O filósofo espanhol fará um exercício interessante a respeito da ironia moderna através de sua proposta de "desumanização" da arte. O texto se inicia apresentando sete características essenciais que diferenciam a arte moderna. Entre elas, a concepção dessa nova forma de expressão como jogo, e a afirmação de que a arte "tende a uma ironia essencial" (ORTEGA Y GASSET, 2007, p. 50). Nesta perspectiva, uma das formas mais evidentes de desumanização

consiste em uma simples mudança da perspectiva habitual. Do ponto de vista humano, as coisas possuem uma ordem, uma hierarquia determinada. Algumas nos parecem muito importantes, outras menos, e ainda, há outras completamente insignificantes. Para satisfazer esse desejo de desumanizar, não há obrigatoriedade de se alterarem as formas primitivas das coisas. Basta inverter as hierarquias e criar uma arte na qual figuram, em primeiro plano, erguidos como monumentos, os elementos menores da vida. (ORTEGA Y GASSET, 2007, p. 52)

Seguindo esta mesma linha de raciocínio, em um capítulo posterior intitulado "Irônico destino", Ortega y Gasset afirma que para seus predecessores, “a arte era algo extremamente sério, quase hierático" (p. 79), enquanto que para ele e para seus contemporâneos,

a própria arte se faz farsa. [...] Nunca havia demonstrado de maneira tão perfeita seu poder mágico, presente, sobretudo, na autoderrisão. Pois, mesmo num gesto de autodestruição, esse poder continua pertencendo à arte e, através de uma dialética maravilhosa, a negação da arte torna-se, ao 
mesmo tempo, sua conservação e seu triunfo (ORTEGA Y GASSET, 2007, p. 80).

Para Ortega y Gasset, a arte ajudará o homem a se colocar em questionamento: "Ser artista não é levar as coisas a sério da mesma forma como fazemos quando não somos artistas" (p. 72).

Ao contrário da concepção de Schlegel, onde a ironia era algo restrito à filosofia e ao artista - que se colocava numa posição igual ou superior a do filósofo -, a perspectiva de Ortega y Gasset é a de que o artista, antes de transformar o caos original em um conjunto harmônico, destruirá todas as aspirações do homem ao Absoluto. Ou seja, embora crie um mundo subjetivo, é o artista que fará com que o homem se aproxime e realmente veja a realidade. A queda, então, se fará necessária.

Em meio a tantas curvas ou caminhos percorridos, o homem moderno reconheceu a própria ironia de sua condição; sua ironia não servirá de meio para escapar da vida sem finalidade, assim como almejava a ironia romântica. Ao contrário, estabelecerá uma moral em harmonia com a sua condição: uma moral irônica. 


\subsection{Diálogos entre dois Pierrots: uma aproximação entre a dor e a ironia}

Ao se definirem a condição do homem e do artista moderno, a ironia servirá, então, como uma espécie de linha tênue entre a tragédia e o sarcasmo, como um ponto de equilíbrio onde não se permite ser exageradamente melancólico nem carregado de humor. Podemos propor que esse equilíbrio, ou melhor, essa linha imaginária da ironia possui diferentes tensões.

No que diz respeito à obra de Jules Laforgue, em vários momentos de sua produção poética percebemos a elasticidade de sua ironia que ora tende ao sarcasmo extremo, ora à tragédia. Antes de propor qualquer definição da ironia laforgueana, seria interessante nos colocar algumas questões: de que é feita essa ironia que o fez ser comparado a Heine ou, ainda, ocupar um lugar de destaque na Anthologie des humoristes français? Por que a ironia é um elemento fundamental na obra de Jules Laforgue?

Uma possível resposta seria pensarmos que a ironia de Jules Laforgue é sempre cruel. O crítico Paul-Jean Toulet observou que em alguns poemas de Le Sanglot de la Terre há "uma espécie de internalização atroz [...] que nos faz acreditar que o "je" possui uma alma sensível" (TOULET, 1974 [1926], p. 31). Eis, então, a ironia de Laforgue: o "je" se mascara, exibe sua falsa armadura sensível, mas, ao mesmo tempo, sublinha espontaneamente, com palavras cruéis, o lado profundo e repugnante da existência.

Essa tendência, que toma conta de seu pessimismo astuto e de cuja esperteza o "je" possui conviç̧ão, acabou tornando-se para Laforgue um sistema complexo que se desenvolveu e se atualizou a partir de Les Complaintes. Em uma das cartas para a sua irmã, antes de finalizar tal coletânea, ele afirma: "São na verdade as sujeiras da vida que devem acrescentar aos versos uma espécie de melancolia humorística." (LAFORGUE, 2000, p. 117) E esse humor melancólico, aliado à experiência da dor e da morte, completará o tom marcante da poesia que Laforgue produzirá até o fim da vida.

$\mathrm{Na}$ fortuna crítica muito se fala a respeito da ironia de Jules Laforgue, mas sem defini-la ou caracterizá-la de forma mais pontual. O que nos leva a crer que um estudo sobre isso se faz necessário uma vez que a ironia de 
Laforgue se distingue claramente de seus contemporâneos. ${ }^{35} \mathrm{~A}$ ironia é seu aporte original e é o ponto de diferenciação específica entre ele e os inúmeros poetas simbolistas.

Sua ironia tem origem no conflito entre sua sensibilidade e sua astúcia sempre presente, mesmo nos instantes de profunda emoção, como uma espécie de prisioneira de um pudor sentimental. Pois, Laforgue nem sempre foi um ironista. Como vimos, sua obra teve sua fase mais filosófica, traduzida poeticamente em seu primeiro livro, Le Sanglot de la Terre. O crítico François Ruchon afirma que "a construção desse caráter irônico em Laforgue é uma atitude complexa que se manifesta sob três aspectos: a ironia sentimental, a ironia filosófica e a ironia metafísica." (RUCHON, 1924, p. 144)

Ruchon define que, o primeiro aspecto, o da ironia sentimental, é o que dá aos poemas a sensação de que o eu lírico, evitando se entregar àquilo que experimenta, com medo de parecer ridículo, ri e se diverte com aqueles que levam tudo a sério. Sua inteligência apodera-se do ridículo (real ou proposital) a favor de sua sensibilidade, interrompendo brutalmente qualquer movimento lírico que pudesse começar ali.

A todo tempo, o "je" laforgueano julga seus estados emotivos, numa espécie de velho hábito de análise interior que compara, opõe e se afasta, por não querer ser vítima de si mesmo, nem de nada nem de ninguém. As piadas e os elementos burlescos ganham espaço para que o leitor enxergue apenas um jogo, mesmo nas declarações mais sinceras.

Assim, esse primeiro aspecto surge a partir de um duplo movimento: ao subjugar as emoções, a ironia consegue frear o desenvolvimento emocional, e provoca - por meio da piada, dos subentendidos etc. - um estado psicológico contrário, de onde nascem o riso e as gargalhadas. Vejamos como isso se apresenta no poema abaixo:

Bref, j'allais me donner d'um "Je vous aime"

Quand je m'avisai non sans peine

\footnotetext{
${ }^{35}$ Villiers de l'Isle Adam também foi um grande ironista, mas uma vez que a ironia de Laforgue é praticada contra ele próprio, para Ruchon, a ironia de Villiers pode ser considerada mais retórica.
} 
Que d'abord je ne me possédais pas bien moi-même. ${ }^{36}$

Em outro trecho, evidenciamos ainda melhor as características desse primeiro aspecto; trata-se de "Autre Complainte de lord Pierrot":

« Jouons au plus fidèle!» - « À quoi bon, ô Nature!

«Autant à qui perd gagne! » Alors, autre couplet :

«Ah! tu te lasseras le premier, j'en suis sûre... »

«Après vous, s'il vous plaît. »

Enfin, si, par un soir, elle meurt dans mes livres,

Douce; feignant de n'en pas croire encor mes yeux,

J'aurai un : «Ah ça, mais, nous avions De Quoi vivre!

«C'était donc sérieux? » ${ }^{37}$

Diferentemente de Bandeira em "Poemeto irônico", por exemplo, os versos de Laforgue terminam no que podemos chamar de zombaria sentimental. Para o "je” laforgueano, a emoção não se desenvolve segundo os modelos sérios e graves que se apresentariam em uma poesia essencialmente lírica. Vejamos como isso se dá nos versos de Bandeira:

O que tu chamas tua paixão,

É tão somente curiosidade.

E os teus desejos ferventes vão

Batendo as asas na irrealidade...

${ }^{36}$ Tradução nossa: "Então, eu direi para mim mesmo um "Eu te amo"/ Quando eu me der conta sem pena/ Que apesar disso eu não me tenho nem a mim mesmo." Trecho extraído do poema "Dimanches", in Derniers Vers, 1890.

37 Tradução nossa: "Brinquemos de ser os mais fiéis!"/ - "E por que faria isso, ó Natureza!/ Tanto perde quem também ganha!" Então, outro casal:/ "Ah! Você se cansará do primeiro, não tenho dúvidas..."/ "Depois de você, por favor."/ Enfim, se, por uma noite, ela morre em meus livros,/ Doce, cansada de não mais acreditar-me em meus olhos,/ Ela me dará um: "Ah, sim, pelo menos temos do que viver!/ "Era, pois, algo sério?". Trecho de "Autre Complainte de lord Pierrot", in Les Complaintes, 1885. 
Curiosidade sentimental

Do seu aroma, da sua pele.

Sonhas um ventre de alvura tal,

Que escuro o linho fique ao pé dele.

Dentre os perfumes sutis que vêm

Das suas charpas, dos seus vestidos, Isolar tentas o odor que tem

A trama rara dos seus tecidos. ${ }^{38}$

$[\ldots]$

O que há de interessante neste poema - além dos jogos com os sentidos da visão e do olfato, da sobreposição cromática (alvura/escuro) e tantos outros elementos constitutivos da forma poética - é que o eu lírico se dissocia de si mesmo para tecer, a partir dessa posição, conclusões sobre a paixão e o desejo que o consomem. O desejo e a paixão são apenas "curiosidade", não passam do plano do imaginário, de uma ilusão: "E os teus desejos ferventes vão/ Batendo asas na irrealidade...”. É nesse distanciamento que o eu lírico se coloca, em um primeiro momento, numa posição irônica: a de que seu desejo de realização é inacessível; e que estar imerso apenas em uma "curiosidade sentimental” não lhe trará a gratificação de seus desejos.

Para Ruchon, Verlaine e Régnier ignoravam a ironia, fugiam do espírito e da "pointe assassine" (RUCHON, 1924, p. 145) característicos desse aspecto, pois sua poesia foi absolutamente tomada por suas emoções, subjugando, por sua vez, a perspicácia irônica do eu lírico. Mais detalhadamente, tais poetas não se dissociavam de seus estados psicológicos, como se dá na maioria dos poemas de Laforgue, em que o eu lírico é capaz de se dissociar inúmeras vezes para duvidar de si ou se questionar. A origem da ironia laforgueana está, portanto, no conflito entre o sentimento e a razão, citado acima, além da sua intensa relatividade das coisas e habilidade de se desprender de si mesmo e ressurgir como algo ou alguém distante.

${ }^{38}$ Trecho de "Poemeto irônico", in A Cinza das horas, 1917. 
Son moi-sujet est dissocie profondément de son moi-objet. L'un contemple autre. Il a ressenti l'étrange étonnement d'éxister, l'étrange sensation d'arriver de très loin en lui, comme en un monde inconnu où tout émeut avec sourire l'âme du contemplateur. ${ }^{39}$ (RUCHON, 1924, p. 149)

Como exemplo dessa dissociação absoluta, vejamos os versos seguintes :

\section{$[\ldots]$}

Ainsi donc, pauvre, pâle et piètre individu

Qui ne croit à son Moi qu'à ses moments perdus,

$[\ldots]$

Un soir, je crus en Moi! J'en faillis me fiancer!

Est-ce possible... Où donc tout ça est-il passé!... ${ }^{40}$

$[\ldots]$

Da mesma forma que ele se desprende de seus sentimentos, o eu lírico faz o mesmo com as ideias. Este é o segundo aspecto de sua ironia. Tal atitude supõe alguns toques de ceticismo, característico de seu tom mais sarcástico. O "je" se sente fatigado de ideias e teorias, vendo nelas apenas um jogo onde o ridículo perfigura em excesso. O "je" parodia e zomba das ideias. Podemos relacionar isso às estranhas divagações filosóficas em seus contos "Salomé" e "Andromède", onde o narrador se lança a uma descrição de "théogonies, théodicées, et formules de la sagesse des nations" (in Moralités Legendaires, 2000, p. 166). Neste caso, sua ironia servirá também como arma depreciativa de todos os valores. Atacando tanto as teorias filosóficas quanto às tradições canônicas da história literária, em seu Moralités Légendaires, seus contos parodiam temas célebres.

${ }^{39}$ Tradução nossa: "O seu eu-sujeito está profundamente dissociado de seu eu-objeto. Um completa o outro. Sente a estranha sensação de existir, de vir de tão longe e chegar até ele, como um mundo desconhecido onde tudo se agita através do sorriso daquele que contempla." ${ }^{40}$ Tradução nossa: [...] Assim, então, pobre, pálido e medíocre indivíduo/ Que acredita em Si apenas nos momentos perdidos,/ [...] Numa noite, eu acreditei em Mim! Queria me comprometer!/ Isso é possível... onde tudo isso aconteceu!...". Trecho de "Dimanches", in Fleurs de Bonne Volonté, 1890. 
O terceiro aspecto é o que podemos chamar de ironia metafísica. Neste caso, o espírito desprendido das teorias e dos sentimentos desprende-se da vida. O pessimismo e o tédio voltam-se contra o próprio sujeito, o obstáculo entre o "je" e o mundo torna-se intransponível. A vida aparece então como um teatro de fantoches efêmeros, como ilusões de um caleidoscópio frenético.

A única atitude que o sujeito julga razoável é de se manter calmo e resignado. É como se não houvesse mais forças para inflar a voz, como fez nos poemas de Le Sanglot de la Terre. Mais tarde isso se tornará algo falso e empolado, e só restará rir diante do desfile das formas efêmeras do mundo. A ironia é, também, sua arma libertadora, onde mais nada o oprime.

O sujeito atinge, assim, a plena liberdade interior, distante do mundo e de qualquer ideologia, de qualquer sentimentalidade. Ele tem apenas sua alma, livre, solitária, no centro de tudo. O excesso de ideias e de emoções agridem o sujeito e o atormentam. Quanto mais consideremos a ironia em Laforgue, mas percebemos que, na realidade, ela é apenas divertida na aparência, ela oculta mornas tristezas e desesperos antigos. Ela descende de um sentimento profundo de desejo pelo absoluto.

Para pensarmos a ironia de Manuel Bandeira e identificar qualquer relação ou diferenciação com a de Jules Laforgue, também seria conveniente nos questionar sobre alguns aspectos: o que afinal eleva tal elemento como algo peculiar na lírica bandeiriana? Por que, apesar do seu aspecto humilde, a ironia é algo que permeia a obra de Bandeira de forma tão especial?

Tomemos como ponto de partida a citação de Haroldo de Campos a respeito de Bandeira:

Bandeira é um desconstelizador. Sua poesia - certa parte dela inscreve-se nessa linha sutil que separa o lugar-comum (a redundância, a frase-feita, o clichê da sensibilidade) da informação original, e que faz muitas vezes que, por uma simples mudança de ângulo de enfoque e/ou de âmbito contextual, o que é redundante passe a produzir essa informação nova; [...] a informação estética de certos poemas bandeirianos nasce do 
deslocamento repentino, fiado numa fímbria de linguagem apenas, do lugarcomum para o lugar-incomum. (CAMPOS, 1980, p. 281)

Esta mudança de "ângulo" ou "âmbito contextual" é o que nos permite, em um primeiro plano, pensar a ironia em Bandeira como articuladora do mecanismo de superação - marca maior de seu plano poético desde os primeiros versos. E, se virmos a ironia como espécie de deslocamento, como uma nova possibilidade de ver o mundo e as coisas, que provoca no sujeito a consciência do que realmente ele é, a poética bandeiriana traz em sua essência todas essas características.

Porque a ironia em Bandeira nem sempre estará relacionada ao cômico ou sarcástico, mas, em princípio, como forma de resposta do "eu lírico" ao processo de aprendizagem para a morte. Segundo Otto Maria Carpeaux, o Bandeira de A cinza das horas, ainda sofria uma certa "tentação de duvidar humoristicamente da própria dor" (CARPEAUX, 1980, p. 266). Por isso, além de estarem relacionados às tradições simbolistas e crepusculares, seus primeiros poemas não trazem o tom humorístico de Libertinagem. O seu riso ainda estava enclausurado pela dor.

Ao contrário do pessimismo extremo de Jules Laforgue que o levava a autoderrisão, os primeiros livros de Bandeira trazem a temática da dor permeada por elementos que impedem que o sujeito lírico se entregue à zombaria de si mesmo: a natureza, o sagrado, as mulheres e a família ainda serão o alicerce que sedimentam as bases para o autoquestionamento e redescoberta de si mesmo.

De certa forma, a "natureza irônica", da qual Bandeira afirmava ter, esteve presente desde o início de sua produção e se desenvolveu à medida em que o poeta também foi acumulando experiências e expandindo suas habilidades para se libertar de vez das amarras de sua formação clássica e parnasiana. Em A cinza das horas, Carnaval e O ritmo dissoluto a ironia já estará presente no que diz respeito ao "deslocamento repentino" que vimos, por exemplo, em "Inútil luar" ou "Gesso".

Este desconforto causado pelos elementos deslocados são o prenúncio do que mais tarde se transformará em humor. Mas, antes de qualquer coisa, sua ironia estaria intimamente ligada ao seu processo de desentranhar a 
poesia. É a partir do reconhecimento de sua condição que o poeta consegue apreender e retirar do lugar-comum o que está ao seu redor. Ao mudar a perspectiva habitual ou inverter as hierarquias de temas propostos na lírica tradicional, operam-se micro-rupturas, já visíveis em poemas como "Oceano" ou, mais adiante, em "Noturno da Mosela" e que mais tarde, em Libertinagem, serão completamente rompidas.

Contudo, Bandeira não se entregará completamente à derrisão como no caso de Laforgue. A corda da ironia se manterá firme, suficientemente tensionada para manter o equilíbrio entre a tragédia e o sarcasmo. Como num picadeiro, ora o sujeito balança para um lado, ora para outro, mas nunca cai no abismo abaixo de seus pés. Bandeira é o malabarista da dor, enquanto Laforgue se desequilibra a todo instante.

Aos poucos, o poeta vai se afastando dos momentos de dor e solidão vividos em sua juventude. Esse acúmulo dos anos que se passam garante a possibilidade do "eu" poder se distanciar de si mesmo para, então, poder rir, se abrir para o humor. Esse distanciamento é gradativo e fundamental para a expansão do humor ou até mesmo do sarcasmo bandeirianos.

O cotidiano será outro elemento profundamente relacionado a ironia em Bandeira. O paradoxo essencial de sua forma será o da simplicidade "que entranha a complexidade e depura a dificuldade em translucidez" (ARRIGUCCI, 2009, p. 129). É por aí, então, que o poeta é capaz de suscitar o mistério da poesia mais alta, desentranhando-a do mundo mediante a linguagem simples, "como se o sublime, cravado na realidade pedestre do cotidiano, ficasse ao alcance do toque da expressão humilde" (p. 130).

A evocação de coisas comuns, conhecidas e observadas, a lição derivada de tradições familiares, rostos e cenas do dia a dia, antes indignos do poeta lírico são elementos que trarão para Bandeira a concretude de sua temática e com isso, a base onde sua poesia se sedimenta.

O cotidiano, como a piada, está impregnado por um potencial artístico vital que Bandeira define como "teor poético", e as realidades concretas se transformam quando vistas através de um véu tênue de reminiscência e ironia. (PONTIERO, 1980, 275) 
Outra hipótese seria dizer que a ironia incorporada em seus poemas corresponde de certa forma a uma transformação visível frente à razão e à emoção, dispondo-se criticamente a contemplar e a aceitar a reconciliação dos contrários, tão própria à faculdade de mudança de perspectiva proporcionada pelo humour.

Contudo, entre várias possibilidades como 0 desestímulo à importância do tema, o exercício das próprias possibilidades estilísticas ou autonomia completa frente ao domínio técnico vão fazer do momento que antecede Libertinagem uma caixa de surpresas para a produção lírica do poeta pernambucano.

De acordo com Sônia Brayner,

A ironia em Manuel Bandeira é uma estratégia intelectual, diluidora da emoção de herança romântica, em que o topos "amor e morte" é reduzido pelo sorriso cético e manipulado por atento ludismo formal. Será um recurso reconhecível em sua obra a quebra da emoção pela antífrase, a mescla dos estilos com o intuito de criar o contraste propício à desmistificação lírica, muitas vezes, com forte dose de grotesco. (BRAYNER, 1980, p. 345)

Para muitos críticos, a publicação de Libertinagem, em 1930, torna-se marco da fase mais significativa de Bandeira como poeta experimental. O clima de ironia ao longo de poemas como "Não sei dançar", "Oração a Teresinha do Menino Jesus" colore a substância temática do verso bandeiriano e, ao mesmo tempo, condiciona sua técnica. É neste livro que ele explora uma variedade de recursos estilísticos para desenvolver com maior nitidez seus dons naturais para o verso humorístico e irônico. É nessa multiplicidade de nuanças que o livro contribuirá para a evolução definitiva de sua obra, caracterizada pela grande riqueza e sutileza de expressão.

A forma por meio da qual Bandeira utiliza o recurso irônico pode servir como orientação à mudança decisiva na sensibilidade do poeta, perceptível não apenas em Libertinagem, mas também em alguns poemas de seus livros anteriores. É evidente que no seu livro de 1930, Bandeira realiza de fato o que ele mesmo chamou de "meu reajustamento ao mundo dos sãos" (BANDEIRA, 
1984 [1954], p. 55) - reajustamento que afetará o conteúdo emocional e filosófico de sua poesia.

O crítico Giovani Pontiero afirma:

Longe de destruir a dimensão trágica que acentua a visão altamente subjetiva de Bandeira, a ambiguidade e as evocações sugestivas de sua ironia dão maior acuidade e pathos à preocupação mórbida do poeta com a vida e toda a situação humana. (PONTIERO, 1980, p. 269)

Libertinagem virá confirmar, então, a nota positiva da lírica bandeiriana, marcando a mudança em relação à introspecção consciente de seus primeiros versos em $A$ cinza das horas. É neste momento que percebemos o rompimento do poeta com "o instinto primitivo do poeta a comprazer-se em confissões românticas em relação a sua doença e condição espiritual” (1980, p. 270). Ao levar essa atitude anti-romântica às vias de fato, Bandeira cria situações burlescas à respeito do mundo doloroso que deixou para trás. O poeta se rende, portanto, à tentação de rir de sua prórpria dor, com uma sensação de constrangimento e alívio quando o eu lírico declara em "Oração a Teresinha do Menino Jesus": "Não sinto mais aquele gosto cabotino da tristeza".

Bandeira se utilizará de muitos recursos estilísticos que contribuirão de forma mais evidente para a faceta multiforme de Libertinagem. Em alguns poemas, a sequência de fatos desconexos e as imagens apresentadas em justaposições, criam uma variedade de associações entre o real e o fantástico:

\section{[...]}

O violoncelista estava a meio do Concerto de Schumann

Subitamente o coronel ficou transportado e começou a gritar:

- "Je vois des anges! Je vois des anges!" -

E deixou-se escorregar sentado pela escada abaixo. ${ }^{41}$

$[\ldots]$

As acumulações, os efeitos ternários e os jogos de rima também criam o efeito cômico, como no caso de "Evocação": "Capibaribe/ Capiberibe";

\footnotetext{
${ }^{41}$ Trecho extraído de "Noturno da Parada Amorim", in Libertinagem, 1930.
} 
"amendoim/ midubim", ou em "Poética": "Estou farto do lirismo namorador/ Poético/ Raquítico/ Sifilítico...".

Os detalhes de sua tragédia pessoal permanecem num tom pungente muitas vezes disfarçado por um pathos burlesco que emerge subitamente numa nota final de zombaria. "Pneumotórax" é o grande exemplo desse processo:

Febre, hemoptise, dispnéia e suores noturnos.

A vida inteira que podia ter sido e que não foi.

Tosse, tosse, tosse.

Mandou chamar o médico:

- Diga trinta e três.

- Trinta e três... trinta e três... trinta e três...

- Respire.

- O senhor tem uma escavação no pulmão esquerdo e o pulmão direito infiltrado.

- Então, doutor, não é possível tentar o pneumotórax?

- Não. A única coisa a fazer é tocar um tango argentino.

Humor e ironia vão conferir uma nova forma de catarse que nasce mais da aceitação do que da fuga. Bandeira finalmente entrega-se à disposição para rir, ou pelo menos sorrir, de coisas ou situações que, encaradas a sério, seriam penosas ou revoltantes.

Nessa mudança de perspectiva, Bandeira assume um comportamento de controle, mas não de combate. Para Sônia Brayner, "a desconstelização deu chance a uma nova faceta, brincalhona, carnavalesca, mascarada, vir à tona. Mas, restou, apesar dos malabarismos de clown, 'uma vida inteira que poderia ter sido e não foi'." (1980, p. 345)

Tendo visto o modo como os poetas reagem à dor com procedimentos ligados à ironia, a representatividade de uma figura recorrente na obra de 
Manuel Bandeira e Jules Laforgue nos levou a definir o passo seguinte para a aproximação das duas obras: o Pierrot será um personagem utilizado pelos poetas como uma espécie de porta-voz da tragédia e da comédia, o único capaz de ser habitado simultaneamente pela dor e pelo riso. Vestidos com suas fantasias saltimbancas, os sujeitos líricos se darão o direito de brincar na corda bamba entre a vida e a morte. 


\subsection{Pierrot apaixonado}

"Um grande amor tem sempre um triste fim

Com o pierrô aconteceu assim

Levando esse grande chute

Foi tomar vermute com amendoim..."

(Noel Rosa e Heitor dos Prazeres, 1935)

De acordo com um estudo de Jean Starobinski (2004), o interesse pelo picadeiro, pela vida nômade do circo, pelo saltimbanco e sobretudo pela figura do clown (que não se reduz ao palhaço, pois envolve o cômico, o humorista) começa no final da Idade Média e do Renascimento, tendo seu ápice a partir do século XIX, ultrapassando esse limite histórico e chegando até os dias de hoje. O que significa isso? O que dizer da particular atração que o circo e seus personagens exerceram não só sobre os poetas mas também sobre pintores de gerações diferentes, como por exemplo, Degas, Picasso e Rouault, ou ainda na música, com compositores como Debussy, Shoenberg, entre outros?

Antes mesmo que os pintores a celebrassem é na literatura, a partir de 1830, que a figura mítica do clown recebe sua primeira elaboração. No poema "Le vin des chiffonniers", de Baudelaire, é possível dizer que o poeta lança um novo olhar em relação a certos espetáculos, até então despercebidos:

On voit un chiffonnier qui vient, hochant la tête,

Butant, et se cognant aux murs comme un poète,

Et, sans prendre souci des mouchards, ses sujets,

Epanche tout son coeur en glorieux projets. ${ }^{42}$

O privilégio concedido às imagens ligadas ao cotidiano, às ruas, aos marginalizados corresponde então ao primeiro desencantamento com as fontes tradicionais de inspiração, oferecendo matéria concreta para um crítica da

\footnotetext{
42 Tradução nossa: "Há o trapeiro que vem movendo a fronte inquieta,/ Nos muros a apoiar-se à imitação de um poeta,/ E sem se incomodar com os policiais desdenhosos,/ Abre seu coração em projetos gloriosos."
} 
cultura. Personagens de vida errante, ciganos e excêntricos, que se reúnem sob a égide da desclassificação social, a família do clown é extensa e vai aparecer no final do século XIX como vestígio do mundo perdido. Starobinski falar de "uma forma singular de identificação" (2004, p. 19) e, de fato, mostra que a escolha do clown não é apenas a seleção de um novo motivo pictórico ou poético, mas uma maneira oblíqua de se colocar a questão da arte, um espécie de paródia.

É nesse ambiente de descontentamento e de ruptura com a realidade frustrada que a figura do clown, representado na forma de Pierrot, vai habitar a obra de Jules Laforgue, e mais tarde, a de Manuel Bandeira. Vejamos em que medida essa figura constituirá um papel importante na configuração das respectivas poéticas e em que momentos elas dialogam:

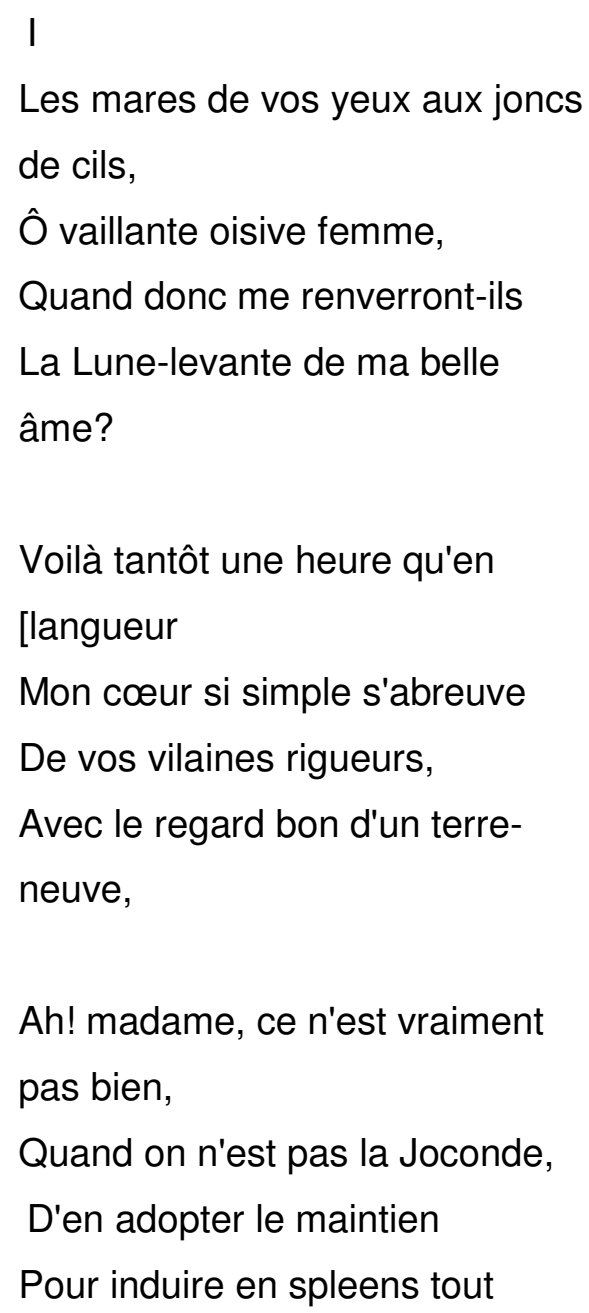

${ }^{43}$ Raça de cão de origem inglesa.
O charco de seus olhos aos juncos de cílios, Ô valente ociosa mulher, Quando então eles refletirão A Lua-crescente de minha bela alma?

Vejam que já passa de uma [hora que em volúpia Meu coração tão simples bebe De suas crueldades abjetas Com o bom olhar de um terra[nova $^{43}$

Ah ! Senhora, não é nada bom Quando não se é a Gioconda De adotar essa atitude Para induzir em spleens tão 
bleus le pauv' monde!

VIII

Ah! tout le long du cœur

Un vieil ennui m'effleure...

M'est avis qu'il est l'heure

De renaître moqueur.

Eh bien? je t'ai blessée?

Ai-je eu le sanglot faux,

Que tu prends cet air sot

De La Cruche cassée?

Tout divague d'amour;

Tout, du cèdre à l'hysope,

Sirote sa syncope;

J'ai fait un joli four.

[...]

XVI

Je ne suis qu'un viveur lunaire

Qui fait des ronds dans les

bassins,

Et cela, sans autre dessein

Que devenir un légendaire.

Retroussant d'un air de défi azuis esse pobre mundo!

Ah! Por todo o meu coração

Aflora-me um velho tédio...

Alertou-me que é hora

De renascer zombeteiro.

Bem? Eu te machuquei?

Será que solucei em falso,

Pelo seu ar idiota

De La Cruche cassée? ${ }^{44}$

Tudo divaga de amor

Tudo, do cedro às folhagens

Engolindo sua síncope

Eu fracassei bonito.
Não passo de um libertino lunar

Que dá voltas nos lagos

$E$ isso, sem outra intenção

Que não apenas tornar-me um legendário.

Levantando com um ar de

[desafio,

${ }^{44}$ La Cruche Cassé é o título dado a uma pintura do século XVIII, do artista Jean-Baptiste Greuze. O quadro retrata uma jovem lânguida de olhar triste e sedutor que tem em suas mãos um vaso de porcelana quebrado. Sua aparência desarrumada e a rachadura na porcelana representam a alegoria da virgindade perdida. 


\begin{tabular}{|c|c|}
\hline Mes manches de mandarin pâle, & $\begin{array}{l}\text { Minhas mangas de oriental } \\
\text { [pálido }\end{array}$ \\
\hline $\begin{array}{l}\text { J'arrondis ma bouche et - } \\
\text { j'exhale }\end{array}$ & $\begin{array}{l}\text { Arredondando minha boca e - } \\
\text { eu exalo }\end{array}$ \\
\hline Des conseils doux de Crucifix. & $\begin{array}{l}\text { Os doces conselhos do } \\
\text { Crucifixo. }\end{array}$ \\
\hline $\begin{array}{l}\text { Ah ! oui, devenir légendaire, } \\
\text { Au seuil des siècles charlatans ! }\end{array}$ & $\begin{array}{l}\text { Ah ! sim, tornar-me legendário, } \\
\text { À entrada dos séculos } \\
\text { charlatões! }\end{array}$ \\
\hline Mais où sont les Lunes d'antan? & $\begin{array}{l}\text { Mas, diga, onde estão as Luas } \\
\text { [de antigamente? }\end{array}$ \\
\hline Et que Dieu n'est-il à refaire $?^{45}$ & $\begin{array}{l}\text { E por que Deus não está a } \\
\text { [refazê-las? }\end{array}$ \\
\hline
\end{tabular}

"O homem morde com o riso". Essa concepção de Baudelaire define perfeitamente a concepção do riso que é criada no poema acima, a partir da figura do Pierrot. Jules Laforgue não foi o único poeta a trabalhar com esta imagem, como vimos acima. Porém, a visão de seu "Pierrot lunaire", ${ }^{46}$ sua relação entre o riso e a melancolia foram largamente trabalhadas em seus livros, mais especificamente em L'Imitation de Notre Dame de la Lune, do qual extraímos o trecho acima.

As "Locutions des Pierrot" é um poema composto de dezesseis partes, cada uma delas divididas igualmente por um poema de três quartetos em um esquema de rimas alternadas $A B A B$. Uma forma bastante simples para uma longa "brincadeira" poética que traz o personagem principal, Pierrot, em uma espécie de jogral, no sentido mais específico da palavra, fazendo gracejos com as palavras e com seu interlocutor, no caso, a mulher amada que o rejeita.

Antes de avaliarmos o caráter formal mais profundamente, seria interessante avaliarmos a escolha do personagem. Como vimos na breve introdução acima, o tema do picadeiro ou mesmo da commedia dell'arte foi

\footnotetext{
45 "Locutions des Pierrots", in L'Imitation de Notre-Dame la Lune, 1885.

${ }^{46}$ Referência ao livro de mesmo nome de Arthur Giraud, publicado em 1884.
} 
algo recorrente no século XIX. Mas por que o poeta Jules Laforgue, diante de tantas outras figuras, escolheu o Pierrot como protagonista de tantos dos seus poemas?

Vejamos o que o dicionário diz a respeito das características dessa figura:

[...] O seu caráter é aquele de um palhaço triste, apaixonado pela Colombina, que inevitavelmente the parte o coração e o deixa pelo Arlequim. [...] A característica principal do seu comportamento é a sua ingenuidade, e é visto como um bobo, sendo sempre o alvo de partidas, mas mesmo assim continua a confiar nas pessoas. Pierrot também é representado como sendo lunático, distante e inconsciente da realidade. (AULETE, 2011, versão on-line).

Ou ainda, vejamos uma imagem bastante marcante, o quadro Pierrot de Jean-Antoine Watteau, de 1718:

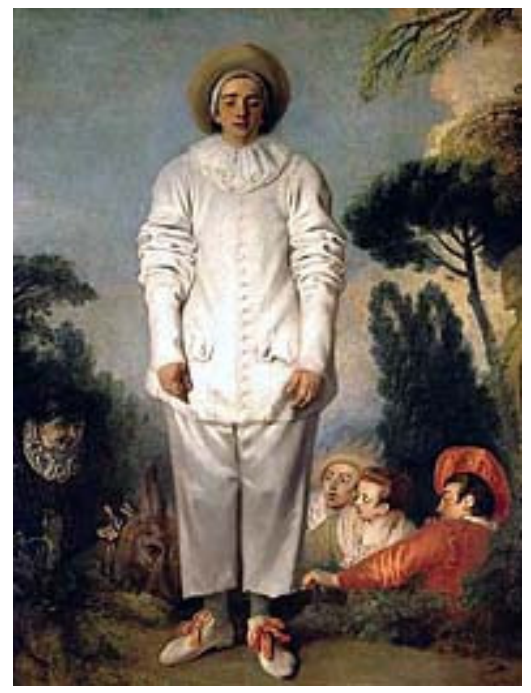

Esse quadro nos mostra de forma bastante clara o semblante triste daquele que, dentre os outros personagens da commedia, tem a função do riso. Essa contrariedade é o que nos parece ser, num primeiro momento, o tema que fará a ligação entre a experiência da dor e da ironia, o que valerá também, em seguida, para Manuel Bandeira. Pois, se para o "je" laforgueano de seus primeiros versos, mais carregados e filosóficos, só a morte era uma possibilidade, agora, após seu desejo de originalidade proposto em Les 
Complaintes, o protagonista de seus versos é alguém que cabe justamente no lugar entre a morte e o riso.

Segundo Luiz Carlos de Brito Rezende, o Pierrot laforgueano "liga-se a embates envolvendo amor e mágoa, produzindo monólogos interiores que levam o sujeito narrativo às próprias lembranças, um relato compulsivo do choque entre idealidade e realidade. E continua:

Laforgue persegue então uma "diç̧ão coloquial", um longo soluço expressivo da miséria anímica do narrador. Para tanto, recorre a um metro flexível e um léxico pouco marcado pela "elevação poética". [...] A mesma busca de uma dicção íntima, "em tom menor", reduz o número de palavras raras e referências míticossimbólicas à devida proporção, sem eliminá-las (nem seria uma preocupação do poeta; além do lado dândico de seu pierrô enluarado, para o público da época suas alusões esparsas eram perfeitamente acessíveis; trata-se de, por assim dizer, de elementos de cultura popular e/ou folhetinesca). (REZENDE, 1997, p.29)

É o momento em que o personagem eleito irá se colocar numa situação de diálogo. Laforgue, em suas cartas a Gustave Kahn, intitula primeiramente o poema de "Sérénades pierrotiques", que podem ser identificadas como um discurso ao Outro, diálogos ou ainda curtas meditações. Em uma linguagem aparentemente simples, sem hermetismos e sem ser audaciosa, escutamos a voz de uma alma órfã, sem perspectiva de encontro com sua alma gêmea.

Na primeira parte, a distância entre Pierrot e sua interlocutora, numa espécie de serenata, é marcada na primeira estrofe: Pierrot evoca a "oisive vaillante femme" [valente ociosa mulher]. Ele reivindica seu olhar, pois só assim, sua alma renascerá, como o nascente da Lua.

Nesse sentido, vemos que a figura feminina é marcada por uma aparência maldosa, hostil, no lugar da musa romântica idealizada em outras épocas. Mulheres como as Salomés de Oscar Wilde ou as de Gustave Maureau, tornam-se, seja pelo desejo que elas concebem, seja pela vingança que despertam, a encarnação de uma harmoniosa e inebriante energia do Mal.

A mulher é considerada um ser naturalmente perverso, pois nela a alma não se separa do corpo. E o corpo é o mal, reino da contingência. Nessa 
medida, quando se vai ao circo, o que se vê é o corpo procurar, através do movimento, a sua redenção.

Provando das "crueldades abjetas" da amada, o "je" se coloca numa posição submissa, comparando-se a um cão: "Avec le regard bon d'un terreneuve" [Com o bom olhar de um terra-nova]. No entanto, na estrofe seguinte, há uma reviravolta: a mulher é comparada a Gioconda, porém há uma quebra irônica no verso no momento em que o "je" a subestima: "Ah! madame, ce n'est vraiment pas bien,/ Quand on n'est pas la Joconde,/ D'en adopter le maintien" [...]. É nesse sentido que a figura clownesca inverte o peso da dor para a derrisão. Mesmo que o riso sirva apenas para a diversão do leitor e não para o "je".

Já na parte VIII, o spleen provocado pela rejeição descrita anteriormente fará renascer em "je" o seu "vieil ennui" [velho tédio]. Pode-se dizer que este tédio é também considerado um dos elementos fundamentais da poesia de Jules Laforgue, pois desde seu livro Le Sanglot de la terre, o pessimismo e o tédio são matérias fundantes de uma poética ligada ao desejo de morte. Mas, aliados à ironia, representam a chave de uma libertação das emoções e da razão.

Para aquele que antes vivia de seu desejo pela morte, a salvação é irônica, porém libertadora. O "je" se liberta no momento em que se utiliza do verbo "renaître" [renascer]: "Um vieil ennui du coeur/ M'est avis qu'il est l'heure/ De renaître moqueur". E, por sua vez, este renascimento é marcado pelo traço "moqueur" [zombeteiro] do sujeito lírico. Contudo essa liberdade conquistada por meio da ironia é algo frustrante para o "je".

Nesta virada, o "je" se vê então capaz de duvidar da pureza de sua amada. Mas a dúvida, ao invés de ser motivo de provocação, é a prova de seu grande fracasso: "J'ai fait un joli four." [Eu fracassei bonito]. É a partir dessa constatação às avessas que passamos à última parte do poema, onde o Pierrot se diz devoto da Lua, um "viveur lunaire" [libertino lunar]. A Lua tem muitas facetas na obra de Jules Laforgue, uma figura que daria um estudo a parte. $O$ que nos ajudaria a compreender aqui seria o fato de que o astro passa a ser então representação mítica daquilo que o Pierrot deseja. Ela pode estar aqui 
disfarçada de mulher, ou seja, é a representante da mulher ideal, não alcançável.

Contudo, a mulher-lua passa a exercer sobre o Pierrot uma espécie de domínio. O sujeito se vê "devoto" desta imagem que paira longe no céu, figura distante da concretude e da realidade. A Lua é, então, divinizada por Pierrot que lhe atribui seu desejo de tornar-se "légendaire" [legendário]. O que resta é apenas a adoração à Lua. Mas o Pierrot de Laforgue se vê mais uma vez diante de uma situação irônica. Ele se dá conta de que a Lua não é mais a mesma e que não há ninguém, nem Deus, capaz de reverter a situação: "Mais où sont les Lunes d'antan?/ Et que Dieu n'est-il à refaire?" [Mas, diga, onde estão as Luas de antigamente?/ E por que Deus não está a refazê-las?]. Contrariamente ao refrão da "Ballade des dames du temps jadis", 47 de Villon, o paralelo se dá de forma bastante esclarecedora: a dor laforgueana representa a perda absolutamente irreparável.

Vejamos agora a análise de "A canção das lágrimas do Pierrot", publicada em Carnaval:
I
A sala em espelho brilha
Com lustres de dez mil velas.
Miríades de rodelas
Multicores - maravilha! -
Torvelinham no ar que alaga
O cloretilo e se toma
Daquele mesclado aroma

\footnotetext{
${ }^{47}$ Vale registrar aqui a primeira estrofe de "Ballade des dames du temps jadis", de François Villon (1431(32)-1463), onde a referência do refrão "Mais où sont les Lunes d'antan?" de Laforgue aparece: "Dictes-moy ou, n'en quel pays,/ Est Flora la belle Romaine,/ Archipiades, ne Thaÿs,/ Qui fut sa cousine germaine,/ Echo parlant quant bruyt on maine/ Dessus riviere ou sur estan,/ Qui beaulte ot trop plus qu'umaine;/ Mais ou sont les neiges d'antan?".
} 
De carnes e de bisnaga. ${ }^{48}$

E rodam mais que confete,

Em farândolas ${ }^{49}$ quebradas,

Cabeças desassisadas

Por Colombina ou Pierrette.

II

Pierrot entra em salto súbito.

Upa! Que força o levanta?

E enquanto a turba se espanta,

Ei-lo se roja em decúbito.

A tez, antes melancólica,

Brilha. A cara careteia.

Canta. Toca. Em com tal veia,

Com tanta paixão diabólica,

Tanta, que se lhe ensanguentam

Os dedos. Fibra por fibra,

Toda a sua essência vibra

Nas cordas que se arrebentam.

III

Seu alaúde de plátano

Milagre é que não se quebre,

$E$ a sua fronte arde em febre,

Ai dele! E os cuidados matam-no.

Ai dele! Que essa alegria,

Aquelas canções, aquele

Susto não é mais, ai dele!

${ }^{48}$ Definição encontrada no dicionário Caldas Aulete (2011): "Tubo cheio de água aromática, us. como brinquedo carnavalesco".

49 Definição encontrada no dicionário Caldas Aulete (2011): "Dança da Provença, sul da França, em que os pares de mãos dadas, enfileirados, se movimentam animadamente". 
Do que uma imensa ironia.

Fazendo à cantiga louca

Dolorido contracanto,

Por dentro borbulha o pranto

Como outra voz de outra boca:

IV

- "Negaste a pele macia

"A minha linda paixão!

"E irás entregá-la um dia

"Aos feios vermes do chão...

"Fiz por ver se te podia

"Amolecer - e não pude!

"Em vão pela noite fria

"Devasto o meu alaúde...

"Minha paz, minha alegria,

"Minha coragem, roubaste-mas

"E hoje a minh'alma sombria

"É como um poço de lástimas..."

V

Corre após a amada esquiva.

Procura o precário ensejo

De matar o seu desejo

Numa carícia furtiva.

E encontrando-o Colombina,

Se lhe dá, lesta, à socapa,

Em vez de beijo uma tapa,

O pobre rosto ilumina-se-lhe!...

Ele que estava de rastros,

Pula, e tão alto se eleva, 
Como se fosse na treva

Romper a esfera de astros!... ${ }^{50}$

Ao escolhermos o poema acima para compor a análise final de nosso trabalho, nos deparamos em primeiro lugar com a semelhança formal apresentada entre o poema de Jules Laforgue e o de Manuel Bandeira. Ambos os poemas possuem uma estrutura divida em partes (dezesseis, no caso de Laforgue e cinco, para Bandeira), compostas por três estrofes de quartetos. Além da adequação formal, notamos também a semelhança temática, onde o Pierrot é, mais uma vez, a figura central do poema. O esquema de rimas seguido por Bandeira é o ABBA. ${ }^{51}$

A dificuldade maior em se trabalhar a análise desse poema consistiu na extensão dos versos. Por isso, para facilitar a compreensão e a leitura, optamos por dividir a análise em três subitens.

\section{a) O salão báquico}

Na primeira parte somos apresentados ao ambiente que irá compor a cena principal. A primeira estrofe descreve 0 salão $e$ as primeiras características desse lugar: "A sala em espelho brilha/ Com lustres de dez mil velas." As aliterações na letra "l" e "m" evocam uma sala carnavalesca báquica, potencializando a sensação vertiginosa do espaço e o movimento dinâmico dos personagens e dos confetes: "Miríades de rodelas/ Multicolores - maravilha! -". Além dos enjambements que, ao longo do poema, conduzirão o ritmo

50 * "A canção das lágrimas de Pierrot”, in Carnaval, 1919.

** Nesta quadra final, Bandeira faz alusão à célebre estrofe de Théodore de Banville (18231891), em seu poema "Le Saut du tremplin", de Odes funambulesques (1857). Nessa estrofe, há a descrição de um clown que, ao pular demasiadamente alto do seu trampolim, irrompe, de forma tão violenta e desastradamente, a lona do circo, projetando-se ao céu, entre as estrelas: "Enfin, de son vil échafaud,/ Le clown sauta si haut, si haut/ Qu'il creva le plafond de toiles/ Au son du cor et du tambour,/ Et, le coeur dévoré d'amour,/ Alla rouler dans les étoiles !".

${ }^{51}$ Nossa escolha também evidencia nossa suspeita de que Bandeira tenha se inspirado em "Locutions des Pierrots" de Laforgue para compor sua "Canção das lágrimas do Pierrot", por se utilizar da mesma estrutura e da mesma temática. 
acentuado e dinâmico propício à festa: "Torvelinham no ar que alaga/ $O$ cloretilo e se toma/ Daquele mesclado aroma/ De carnes e de bisnaga."

Um Carnaval alegre, multicolor, perfumado e iluminado. O movimento da música e dos confetes é agilmente transferido aos personagens que integram a festa: "E rodam mais que confete,/ Em farândolas quebradas,/ Cabeças desassisadas/ Por Colombina ou Pierrette." E então, uma das figuras centrais do poema aparece no meio da multidão.

Lembremos também que as figuras da Commedia dell'Arte são figuras tradicionais dessa manifestação popular. N'“A canção de lágrimas do Pierrot”, Manuel Bandeira se utiliza de personagens da tradição para compor seu universo carnavalesco. E, além das personagens, a escolha dos vocábulos é perfeitamente integrada ao ritmo dos versos, o que configura a graciosidade e leveza do poema. É nesse sentido que vemos que a poesia de Manuel Bandeira ainda estava integrada às tradições da forma e dos temas.

$\mathrm{Na}$ primeira parte vimos como o ambiente do salão se constitui. Em seguida, a figura do Pierrot é apresentada ao leitor. Mais uma vez marcando o ritmo, as aliterações em "t" nos dão a ideia do movimento do pulo: "Pierrot entra em salto súbito./ Upa! Que força o levanta?". A imagem do salto representa "a destreza, a leveza, o voo, isto é, um corpo em movimento, cuja potência extraordinária realiza em plena luz maravilhas das quais a humanidade vulgar é incapaz." (STAROBINSKI, 2004, p. 24). Nessa medida, o ato acrobata do Pierrot é considerado como equivalente alegórico do ato poético. É a altitude vertiginosa a dimensão privilegiada do Pierrot, o qual, em muitos poemas, adquire o caráter estelar ("Pierrot lunaire").

A interjeição "Upa!", marca também o despojamento da linguagem e a coloquialidade já utilizada por Bandeira em Carnaval. A partir do contraste entre o vocabulário mais rebuscado e a linguagem coloquial, também notamos a utilização de neologismos, como no caso de "A cara carateia." Todo esse contraste está ligado à brincadeira carnavalesca. O ritmo, as rimas, toda a constituição do poema evidencia a cadência musical, própria ao momento festivo.

Além do contraste sonoro, a movimentação do personagem é composta a partir das imagens de salto e de queda: "Pierrot entra em salto 
súbito." X "Ei-lo se roja em decúbito." É a partir desse movimento que outros contrastes irão se construir durante a cena: a tez melancólica de Pierrot brilha ao ver sua amada. Contudo, Colombina é a responsável por sua "paixão diabólica".

Na passagem do oitavo para o nono e ainda do nono para o décimo verso, a uma sequência de enjembements que quebram o ritmo dinâmico construído até então: "Com tanta paixão diabólica,/ Tanta, que se the ensanguentam/ Os dedos. Fibra por fibra,". O final dessa apresentação nos remete ao caráter trágico do Pierrot bandeiriano: "Toda a sua essência vibra/ Nas cordas que se arrebentam".

Muito além deste caráter trágico representado nesta primeira parte do poema, a chegada do Pierrot bandeiriano faz referência à transgressividade desta figura. Para Starobinski, "o clown opera uma passagem - do peso à leveza, do exercício imperfeito à perfeição da habilidade, da não-obra à obra realizada." (2004, p. 27). Compreende-se porquê, no circo, da grande importância dada ao momento de seua entrada no picadeiro:

Todo verdadeiro clown surge de um outro espaço, de um outro universo: sua entrada deve figurar uma transgressão dos limites do real [...] sua aparição tem por fundo um abismo aberto donde ela se projeta para nós (STAROBINSKI, 2004, p. 27)

\section{b) Um dolorido contracanto}

Nesta parte seguinte, Pierrot é motivado a cantar sua dor. Sua "paixão diabólica" o faz arder em febre, sangrar os dedos, romper as cordas de seu alaúde. Como vimos no poema de Laforgue, a mulher exerce aqui uma postura maléfica sobre o sujeito lírico. Ela pode, muitas vezes, ser comparada à morte. É algo desejado, porém inatingível. Colombina, além da atração exercida pelo Pierrot, também dá ao poema um caráter vertiginoso que o leva ao desespero. A tragédia de Pierrot é então revelada: "Ai dele! Que essa alegria,/ Aquelas canções, aquele/ Susto não é mais, ai dele!/ Do que uma imensa ironia."

É aqui que chegamos a um ponto muito importante de nossa análise. A "imensa ironia" da qual o sujeito é "vítima" é algo profundamente melancólico, 
voltado para sua experiência com a dor e a rejeição. Essa ironia é aquela que poderá ser vista em outros momentos da obra de Bandeira, aquela que, como pudemos notar, Ihe servirá como forma de distanciamento, de constatação de suas perdas. Apenas a partir dessa ironia que o eu lírico permitirá se afastar para ver sua dor com outros olhos. Embora ainda em Carnaval a ironia estivesse "enclausurada pela dor", Pierrot é o portador maior desse afastamento. Em seu "dolorido contracanto", a dor terá uma outra voz, uma voz interna: "Por dentro borbulha o pranto/ Como outra voz de outra boca:".

O pranto do Pierrot então se faz ouvir. Ele é a prova da dor e da rejeição provocadas por sua amada. É nesse momento que essa outra voz permite ao sujeito o distanciamento, fazendo com que seu canto, antes de ser proferido à Colombina, ecoe a si mesmo. Diferentemente do lamento do Pierrot de Laforgue à Lua, aqui, a voz interna é severamente poderosa, pois há na falta de esperança uma dor sem saída: "Minha paz, minha alegria,/ Minha coragem, roubaste-mas".

\section{c) 0 salto rumo às estrelas}

Após ouvirmos o pranto de Pierrot, chegamos enfim à cena final desse retrato do Carnaval bandeiriano. Há uma quebra de expectativa já no primeiro verso: "Corre após a amada esquiva/ Procura o precário ensejo". Após constatar que sua alma estava perdida na dor e na rejeição, Pierrot insiste em "matar o seu desejo numa carícia furtiva".

Quando enfim, após esse longo e doloroso trajeto até sua amada, quando enfim a encontra, temos a prova da decepção: "Se lhe dá, lesta, à socapa,/ Em vez de beijo uma tapa". Vale registrar aqui um breve comentário feito por Bandeira em uma de suas cartas à Mário de Andrade exclusivamente sobre esses versos: Depois, Mário, o Brasil é muito grande... [...] Quanta coisa se desconhece! Aqui diz-se "um tapa". Pois em Pernambuco só se diz "uma tapa". [...] A tapa dos meus versos é provincianismo e não lusitanismo (BANDEIRA [1924] apud MORAES, 2001, p. 166).

É nesse sentido que podemos constatar que havia então uma primeira tentativa de imprimir em sua poesia a linguagem própria às suas 
reminiscências, à sua oralidade pernambucana. Além dessa "quebra" pelo "provincianismo" marcado em seu vocabulário, há a ruptura na expectativa: "O pobre rosto ilumina-se-lhe!....". O uso do pronome reflexivo e do oblíquo ressalta ainda mais a ideia de luminosidade. Além disso, notamos se faz necessária uma pausa, como se todos os holofotes se voltassem para os dois personagens do Carnaval.

O movimento rumo às estrelas define o Pierrot como o "senhor da vertigem", como leveza aérea ideal. E essa leveza terá outros desenvolvimentos. No caso da obra de Bandeira, a superação será o desenvolvimento mais representativo dessa capacidade de voar. A viagem do Pierrot aos céus representa o momento do salto perigoso, do obstáculo ultrapassado, dos círculos de fogo perfurados na travessia. A dor que fora percorrida antes do obstáculo é, enfim, ultrapassada pelo salto vertiginoso da ironia, dando ao eu lírico bandeiriano a liberdade de "duvidar humoristicamente da própria dor". ${ }^{52}$

${ }^{52}$ Retomamos a referência citada anteriormente, extraída do ensaio de Otto Maria Carpeaux, "Ensaio de exegese de um poema de Manuel Bandeira", in Manuel Bandeira - Coleção Fortuna Crítica 5. São Paulo: Civilização Brasileira, 1980. 
CONSIDERAÇÕES FINAIS 


\section{"Sono il saltimbanco dell'anima mia"53}

O exercício feito a partir das análises apresentadas nesta dissertação nos permitiu observar, ainda que de maneira sobrevoada, o movimento entre a dor e a ironia nos poemas de Jules Laforgue e Manuel Bandeira. Não houve intenção de esgotar ou chegar a conclusões sobre o que esses temas representaram nas duas obras. Contudo, o processo de comparação serviu para nos apresentar algumas características comuns, como a relação entre 0 desejo de morte e a disponibilidade para o riso, manifestadas de forma diversa em cada uma das obras.

Neste sentido, pode-se perceber que Laforgue influenciou Bandeira não apenas por estar inserido na escola simbolista, assim como tantos outros poetas o fizeram. Os elementos que os aproximam estão justamente relacionados ao verso adaptado por Bandeira, visto na introdução desta dissertação: "Que je suis piètre et sans génie" [Como sou medíocre e sem talento]. A ironia se desenvolve no convívio com a dor e, no caso do eu lírico bandeiriano, ela intensificará o processo de superação. Já para Laforgue, a ironia é a sua grande arma, a chave que the permite o desenvolvimento de seu projeto em busca de uma linguagem original, mas não o salva de uma desolação sem remédio.

Nos dois casos, a proximidade com a experiência da morte permitiu aos poetas criar um estilo próprio para driblar a dor. Laforgue fez do seu estilo a derrisão. Como vimos, o "je" laforgueano é atravessado por diversas vozes que chamam melancolicamente por alguém que não está mais ali ou é inatingível (a mãe, a amada e a Lua). Essas vozes marcadas pelo tom irônico evidenciam como o poeta se utiliza, de maneira original, das armas da ironia contra o silêncio definitivo. Seu estilo zombeteiro permitiu ao "je" criar facetas para contornar a dor e a solidão.

\footnotetext{
${ }^{53}$ Verso extraído do poema "Chi Sono?", do poeta crepuscular italiano Aldo Palazzeschi, citado por Bandeira na continuação da carta a Mário de Andrade citada no capítulo anterior: "[...] Perdão, Mário: 'sono il saltimbanco della anima mia!' É o que justifica ou pelo menos desculpa. [...]" (BANDEIRA [1924] apud MORAES 2001, p. 166).
} 
Uma das facetas que mais marcou sua obra poética é a figura do Pierrot. A presença desta personagem está em mais de um livro e em um deles, L'Imitation de Notre Dame la Lune, o Pierrot protagoniza a maioria dos versos. Laforgue se utiliza desta figura para trabalhar a questão da dor de uma forma diferenciada: o universo do picadeiro traz a abertura ao tom de brincadeira, o espetáculo vertiginoso entre a tragédia e a comédia.

Para Starobinski (2004), são as direções inversas e complementares tragédia e comédia - que a figura do clown evoca, com o desejo de ultrapassar o mundo ou, mais exatamente, de introduzir no mundo o testemunho de uma trajetória vinda de algum lugar ou visando um outro lugar.

Sob o aspecto de vítima expiatória, o Pierrot pode ser considerado aquele que é "expulso do mundo", carregando consigo nossos pecados e nossas vergonhas. É ele quem passa pela morte e por sua vez, nos faz experimentar tal sensação. Em "Locutions de Pierrots", por exemplo, o "je" laforgueano revela esta sensação de estar perdido, de cobrir com sua fantasia as piores angústias ou decepções vividas. Sua condição "apequenada" diante do mundo está representada na sua fantasia de Pierrot: a brincadeira irônica transforma-se na peripécia diante do jogo perdido.

Já em Bandeira vimos que a ironia desenvolvida em seus versos está relacionada a outros elementos fundantes de sua obra poética: de um lado, a dor, a morte, a solidão; de outro, o cotidiano, a religiosidade, o estoicismo, o consolo. O caráter de superação aliado à inversão das situações trágicas pode ser considerado a base de sua ironia. Em nosso percurso, fizemos um caminho complexo para voltar a Carnaval, seu segundo livro, onde o eu lírico bandeiriano se veste de Pierrot e sai pelos salões para aprender com a vida. Esse movimento de saída, de abertura para o mundo fora do apartamento é o aprendizado que será adquirido para enfrentar a morte. Em um belo depoimento a respeito de Carnaval, Mário de Andrade afirma:

Manuel é finíssimo irônico. Pois na Cinza das horas até isso é convencional. Poemas como "Cartas ao meu avô", "Inútil luar", "Chama e fumo", mesmo o "Três idades" representam aquele humorismo desengonçado, epidérmico, mania de alguns poetas nossos [...]. Não há dúvida. Manuel escutava as visitas e se vestia diante do espelho. 
Mas eis que abandona o espelho e sai na rua num domingo de Carnaval. Pôde em seguida voltar para casa e se conhecendo bem. Porque não é olhando no espelho que uma pessoa aprende, mas ensaiando todos os muques físicos e psíquicos ao contato da vida. [...]

Com o Carnaval Manuel se aprendeu vivendo. [...] Depois é que sabido de si, Manuel possuído por Manuel, pôde voltar pro quarto e contemplar da janela as ruas de pobre destino. (ANDRADE, 1987 [1924], p. 77)

Por isso, voltamos a Carnaval para recuperar um elemento importante: a partir da figura do Pierrot, Manuel Bandeira afirma toda a positividade de sua poesia, deixando transparecer por meio do véu fino da melancolia a brincadeira no tratamento das questões sobre a vida e a morte. Quando, enfim, em "Canção das lágrimas do Pierrot", seu eu lírico volta a pôr os pés no chão após "uma tapa", os elementos do seu cotidiano vão pouco a pouco recompondo o que havia sido quebrado pelas experiências do passado, assim como vimos em "Gesso", transformando-o no porta-voz de seu cotidiano, num casamento perfeito entre humildade e ironia.

A inversão irônica é, antes do riso, a leveza conquistada por aquele sujeito fundado na dor. É a partir do deslocamento proposto em "Inútil Luar", por exemplo, que Bandeira redireciona sua experiência com a morte, ampliando os aspectos afirmativos da vida. Em "Renúncia", o convívio com a dor o faz capaz de observar tal ideia como um princípio disjuntivo, como recusa da permanência do mesmo. Ou ainda em "A Virgem Maria", quando vimos que o chamado da santa para o mundo lá fora persiste mesmo abaixo da terra. A superação indica, portanto, a permanência de tudo o que reafirma a vida.

O Pierrot bandeiriano é aquele que tem a necessidade da fantasia derrisória, da vestimenta clownesca para nos fazer provar da infinita tristeza que habita sua alma exilada de seu verdadeiro lugar, na sua condição "saltimbanca" de uma vida errante. O poeta possui o privilégio de ler nesta figura uma verdade dissimulada, que confere ao Pierrot uma superioridade e 0 torna, então, rei da ironia. Toda esta representação reafirma, humildemente, a inversão proposta no final da "Canção", de Bandeira. E o leitor percebe que o Pierrot representa, portanto, todos nós. Para Starobinski, o clown é o portador da condição humana que, ao se colocar na posição humilde do palhaço, 
revelando ao leitor (espectador) o papel pitoresco que cada um de nós exerce na comédia do mundo. (2004, p. 88).

A partir desses elementos e de outros que poderão ser considerados em futuras pesquisas, o breve comentário sobre a representatividade desta figura nas obras de Laforgue e Bandeira nos fez chegar, enfim, ao ponto convergente desta comparação: a presença do Pierrot consiste, portanto, no plano de uma condensação imagética para onde confluiriam as vertentes complementares da dor e da ironia, uma possível síntese dos temas trabalhados nesta pesquisa. 


\section{REFERÊNCIAS BIBLIOGRÁFICAS}

ABRAHAM, Nicolas; TOROK, Maria. A casca e o núcleo. São Paulo: Editora Escuta, 1995.

ADORNO, Theodor W. Notas de Literatura I. São Paulo: Editora 34, 2003.

ALLEMANN, Beda. "De l'ironie em tant que príncipe littéraire". In: Poétique. $\mathrm{n}^{\circ}$ 36, nov. 1978.

ALVES, Cilaine. O belo e o disforme: Álvares de Azevedo e a Ironia Romântica. São Paulo: Edusp, 1998.

ANDRADE, Carlos Drummond et alli. Homenagem a Manuel Bandeira (1936). São Paulo: Fac-símile, 1986.

ANDRADE, Mário. "Manuel Bandeira" (1924). In: LOPEZ, Telê Porto Ancona (org.), Manuel Bandeira: Verso e Reverso. São Paulo: T. A. Queiroz, 1987.

ARRIGUCCI Jr., Davi. Enigma e comentário. São Paulo: Companhia das Letras, 1987.

Humildade, paixão e morte: A poesia de Manuel

Bandeira. São Paulo: Companhia das Letras, 1990.

AUDEN, W. H. Calma mesmo na catástrofe. Florianópolis: Editora Noa Noa, 1986.

BALAKIAN, Anna. O Simbolismo. São Paulo: Perspectiva, 1985.

BANDEIRA, Manuel. Poesia Completa e Prosa. Rio de Janeiro: Nova Aguilar, 1977.

. Itinerário de Pasárgada. Rio de Janeiro: Nova Fronteira, 1984.

Estrela da vida inteira: poesia completa. Rio de Janeiro: Nova Fronteira, 2009.

BAUDELAIRE, Charles. "Le Peintre de la vie Moderne ». In: CEuvres II. Paris: Gallimard, Bibliothèque de la Pléiade, 1951.

BERARDINELLI, Alfonso. Da poesia à prosa. São Paulo: Cosac Naify, 2007. 
BERMAN, Marshall. Tudo que é sólido desmancha no ar. São Paulo: Companhia das Letras, 2001.

BERTRAND, Jean-Pierre. Les Complaintes De Jules Laforgue: Ironie et Désenchantement. Paris: KLINCKSIECK, 1988.

BLANCHOT, Maurice. O espaço literário. Rio de Janeiro: Rocco, 1987.

BOSI, Alfredo. O ser e o tempo da poesia. São Paulo: Companhia das Letras, 2000.

BOURGEOIS, René. L'ironie Romantique. Grenoble: Presses Universitares, 1974.

BRADBURY, M. e McFARLANE, J. (org.). Modernismo: guia geral 1890-1930. Trad. Denise Bottmann. São Paulo: Companhia das Letras, 1989.

BRAYNER, Sônia (org.). Manuel Bandeira. Rio de Janeiro: Civilização Brasileira, 1980 [Coleção Fortuna Crítica, vol. 5].

BRUNEL, Pierre (org.). Lectures d'une œuvre Les Complaintes de Jules Laforgue. Paris: Éditions du temps, 2000.

BÜRGER, Peter. Teoria da vanguarda. São Paulo: Cosac Naify, 2008.

CAMILO, Vagner. Risos entre pares: poesia e humor românticos. São Paulo: Edusp, 1997.

CANDIDO, Antonio. Literatura e sociedade. São Paulo: PubliFolha, 2000.

CARPEAUX, Otto M. Ensaio de exegese de um poema de Manuel Bandeira. In: Brayner, Sônia (org.), Manuel Bandeira. São Paulo: Civilização Brasileira, 1980, p. 198 [Coleção Fortuna Crítica, vol. 5].

CHAMBERS, Ross. Mélancolie et Opposition: Les débuts du modernisme en France. Paris: Librairie José Corti, 1987.

DIONISIO, Gustavo Henrique. Pede-se abrir os olhos. Psicanálise e reflexão estética hoje. 2010. 327f. Tese (Doutorado em Psicologia) - Instituto de Psicologia, Universidade de São Paulo (no prelo).

DUARTE, Lélia Parreira. Ironia e humor na literatura. Belo Horizonte: Alameda \& Editora Puc Minas, 2006.

ELIOT, T. S. A essência da poesia. Rio de Janeiro: Artenova, 1972. 
ENZENSBERG, Hans Magnus. Com raiva e paciência: Ensaios sobre literatura, política e colonialismo. São Paulo: Paz e Terra, 1985.

FAUSTINO, Mario. Artesanatos de poesia. São Paulo: Companhia das Letras, 2004.

FRAYZE-PEREIRA, João A. Arte, Dor. Inquietudes entre estética e psicanálise. São Paulo: Ateliê Editorial, 2005.

FREUD, Sigmund. "La interpretación de los sueños" (1900). In: Obras Completas, vol. IV. Buenos Aires: Amorrortu, 1996. . "Duelo y Melancolia" (1917). In: Obras Completas, vol. XIV. Buenos Aires: Amorrortu, 1996.

FRIEDRICH, Hugo. Estrutura da lírica moderna. São Paulo: Livraria Duas Cidades, 1978.

GLEDSON, John. Influências e impasses: Drummond e alguns contemporâneos. São Paulo: Companhia das Letras, 2003.

GOLDSTEIN, Norma. Do Penumbrismo ao Modernismo: o primeiro Bandeira e outros poetas significativos. São Paulo: Ática, 1983.

GOMES, A. C. O Simbolismo. São Paulo: Ática, 1994.

GROJNOWSKI, Daniel. Jules Laforgue: spectacle et oralité. Universidade de Paris VII:

http://orsini.net.online.fr/laforgue/vortex/grojno1.htm.11/08/2001. L'Esprit Fumiste et les rires fin de siècle. Paris : José Corti, 1990.

GUICHARD, Léon. Jules Laforgue et ses poésies. Paris: Nizet, 1977.

GUIMARÃES, Julio Castañon. Por que ler Manuel Bandeira. São Paulo: Editora Globo, 2008.

GUYAUX, André; MARCHAL, Bertrand. Jules Laforgue: Colloque de la Sorbonne. Paris: Presses Universitaires de Paris-Sorbonne, 2000.

HAMBURGUER, Michael. A verdade da poesia. São Paulo: Cosac Naify, 2007.

HOLANDA, Sérgio B. "Trajetória de uma poesia". In: Brayner, Sônia (org.), Manuel Bandeira. São Paulo: Civilização Brasileira, 1980, p. 142 [Coleção Fortuna Crítica, vol. 5]. 
HOLMES, Anne. Oralité et Vers Librisme. Oxford University:

http://orsini.net.online.fr/laforgue/vortex2/holmes1.htm.12/08/2001. . "Le contrapoint dans Les Complaintes». In: Les

Complaintes de Jules Laforgue: L'idéal et Compagnie. Romantisme Colloques, Société des Études Romantiques. Paris: Édition Sedes, 2000.

HUTCHEON, L. Teoria e Política da Ironia. Trad. Julio Jeha. Belo Horizonte: UFMG, 2000.

Uma teoria da paródia. Lisboa: Edições 70, 1985.

JAPP, Uwe. Theorie der Ironie. Frankfurt am Main: Vitorio Klostermann Verlag, 1983.

KIERKEGAARD, Soren A. O Conceito de Ironia: constantemente referido a Sócrates. Petrópolis: Editora Vozes, 1991.

LAFORGUE, Jules. Les Complaintes. Paris: Imprimerie Nationale, 2000.

Mélanges posthumes. In: Henri Scepi (org.) Les Complaintes de Jules Laforgue. Paris: Gallimard, 2000.

. CEuvres complètes, t. I e II. Paris: L'Âge d'Homme, 1986, 1995.

LAPLANCHE, Jean; PONTALIS, Jean-Bertrand. Vocabulário da psicanálise. São Paulo : Martins Fontes, 1979.

LEITE, Sebastião Uchoa. Crítica de ouvido. São Paulo: Cosac Naify, 2003.

LOPEZ, Telê Porto Ancona [org.]. Manuel Bandeira: Verso e Reverso. São Paulo: T. A. Queiroz, 1987.

MAN, Paul de. "The Rethoric of Temporality". In: Blindness \& Insight: Essays in the Rethoric of Contemporary Criticism. Londres: Routledge, 1993 (2a. ed.)

. The Rhetoric of Romanticism. Nova York: Columbia University Press, 1984.

MICHAUD, Guy. Message poétique du Symbolisme. Paris: Nizet, 1947.

MORAES, Marco Antonio (org.). Correspondência Mario de Andrade \& Manuel Bandeira. São Paulo: Edusp, 2001. 
MORETTO, F. M. L. (Org.). Caminhos do decadentismo francês. São Paulo: Edusp/Perspectiva, 1989.

. Letras Francesas: estudos da literatura. São Paulo:

Edunesp, 1994.

MARQUES, Pedro. Manuel Bandeira e a Música: Com três poemas visitados. São Paulo: Ateliê Editorial, 2008.

MOURA, Murilo Marcondes de. Manuel Bandeira. São Paulo: Publifolha, 2001.

MUECKE, D. C. « Analyses de l'ironie ». In: Poétique. n. 36, nov. 1978. . Ironia e o irônico. São Paulo: Perspectiva, 1995

(Debates, 250).

NESTROVSKI, Arthur. Ironias da modernidade. São Paulo: Editora Ática, 1996.

OEHLER, Dolf. Terrenos vulcânicos. São Paulo: Cosac Naify, 2004.

ORTEGA Y GASSET, J. La deshumanización del arte y otros ensayos de estética. Madri: Austral, 2007.

OSMONT, Anne. "Jules Laforgue". In: Le Mouvement Symboliste. Paris: Maison du Livre, 1917.

PAZ, O. A outra voz. Trad. de Wladir Dupont. São Paulo: Siciliano, 1993.

. "A consagração do instante". In: $\mathbf{O}$ arco e a lira. Rio de Janeiro: Nova Fronteira, 1982 ( $2^{\mathrm{a}} \mathrm{ed}$.).

PEYRE, Henri. A Literatura Simbolista. São Paulo: Cultrix: USP, 1983.

PLATÃO. A República. São Paulo: Perspectiva, 2006.

PONTALIS, Jean-Bertrand. Entre le rêve et la douleur. Paris: Gallimard, 1977.

Perder de vista: da fantasia de recuperação do objeto perdido. Rio de Janeiro: Zahar, 1991.

PONTIERO, Giovanni. "A expressão da ironia em Libertinagem". In: Brayner, Sônia (org.), Manuel Bandeira. São Paulo: Civilização Brasileira, 1980, p. 267 [Coleção Fortuna Crítica, vol. 5]. 
POUND, E. "Ironia, Laforgue e um Pouco de Sátira". In: A Arte da Poesia. São Paulo: Cultrix, 1976.

REBOUL, Pierre. Laforgue. Paris: Hatier, 1960.

REZENDE, Luís Carlos de Brito (org.). Últimos poemas do Pierrô Lunar. Rio de Janeiro: Sete Letras, 1997.

RONGIER, Sébastien. De l'ironie: Enjeux critiques pour la modernité. Paris: Klincksieck, 2007.

ROSENBAUM, Yudith. Manuel Bandeira: uma poesia da ausência. São Paulo: Edusp, 1997.

RUCHON, François. Jules Laforgue (1860-1887): Sa vie et son œuvre. Genebra: Editions Albert Ciana, 1924.

SACRAMENTO, Mário. Eça de Queirós: Uma estética da ironia. Lisboa: Imprensa Nacional - Casa da Moeda, 2002.

SCEPI, Henri. Les complaintes de Jules Laforgue. Paris: Folio, 2002.

SCHLEGEL, Friedrich. Fragments. Paris: José Corti, 1996.

SCHOPENHAUER, Arthur. 0 mundo como vontade e representação. São Paulo: Abril Cultural, 1999 [Os Pensadores].

SCHOENTJES, Pierre. Poétique de l'ironie. Paris : Seuil, 2001.

STAROBINSKI, Jean. Portrait de l'artiste en saltimbanque. Paris : Gallimard, 2004.

SZONDI, Peter. Poésie et Poétique de l'idéalisme allemand. Paris : Gallimard, 1975.

SYLVOS, Françoise. "Laforgue et la poétique de la Complainte populaire". In: Les Complaintes de Jules Laforgue, L'idéal et Compagnie. Romantisme Colloques - Société des Études Romantiques. Paris: Édition Sedes, 2000.

TELES, Gilberto M. "A 'Belle Époque'”. In: Vanguarda européia e Modernismo brasileiro: apresentação dos principais poemas, manifestos, prefácios e conferências vanguardistas, de 1857 a 1972. Petrópolis, RJ: Vozes, 1992 (11 ed.)

A experimentação poética em Manuel Bandeira. Revista ICALP, vol. 06, Agosto/Dezembro de 1986. 
VECCHI, Roberto. "Aliança na poeira. (Re)Leitura de alguns poemas de Manuel Bandeira à luz ardente do crepúsculo italiano". In: Lanciani, Giulia (coord.), Manuel Bandeira - Libertinagem e Estrela da Manhã - Edição Crítica. São Paulo: Scipione, 1998, p. 286.

VILLAÇA, Alcides. "O resgate íntimo de Manuel Bandeira". In: LOPEZ, Telê Porto Ancona (org.), Manuel Bandeira: Verso e Reverso. São Paulo: T. A. Queiroz, 1987.

WILSON, E. "O Simbolismo". In: O Castelo de Axel: estudo sobre a literatura imaginativa de $\mathbf{1 8 7 0}$ a 1930. Trad. de José Paulo Paes. São Paulo: Cultrix, 1967. 